PNL-2933

UC-41

\title{
Environmental Status of the Hanford Site for CY 1978
}

J. R. Houston
P. J. Blumer

August 1979

Prepared for the U.S. Department of Energy under Contract EY-76-C-06-1830

Pacific Northwest Laboratory Operated for the U.S. Department of Energy by Battelle Memorial Institute 


\title{
NOTICE
}

This report was prepared as an account of work sponsored by the United States Covernment. Neither the United States nor the Department of Energy, nor any of their employees, nor any of their contractors, subcontractors, or their employees, makes any warranty, express or implied, or assumes any legal liability or responsibility for the accuracy, completeness or usefulness of any information, apparatus, product or process disclosed, or represents that its use would not infringe privately owned rights.

The views, opinions and conclusiors contained in this report are those of the contractor and do not necessarily represent those of the United States Government or the United States Department of Energy.

\author{
PACIFIC NORTHWEST LABCRATORY \\ operated by \\ BATTELLE \\ for the \\ UNITED STATES DEPARTMENT OF ENERGY \\ Under Contract EY-76-C-06-1830
}

\author{
Printed in the United States of America \\ Available from \\ Aational Technical Information Service \\ United States Department of Commerce \\ 5285 Port Royal Road \\ Springtieid, Virginia 22151
}

Price: Printed Copys.

$\therefore$ Microfiche $\$ 3.00$

$\begin{array}{cc}\text {-Pages } & \begin{array}{c}\text { NTIS } \\ \text { Selling Price }\end{array} \\ 001-025 & \$ 4.00 \\ 026-050 & \$ 4.50 \\ 051-075 & \$ 5.25 \\ 076-100 & \$ 6.00 \\ 101-125 & \$ 6.50 \\ 126-150 & \$ 7.25 \\ 151-175 & \$ 8.00 \\ 176-200 & \$ 9.00 \\ 201-225 & 59.25 \\ 226-250 & 59.50 \\ 251-255 & \$ 10.75 \\ 276-300 & 511.00 \\ & \end{array}$




\section{9}

ENVIRONMENTAL STATUS OF THE HANFORD SITE FOR CY 1978
J. R. Houston
P. J. Blumer

August 1979

Prepared for

the U.S. Department of Energy under Contract EY-76-C-06-1830

Pacific Northwest Laboratory Richland, Washington 99352 

CONTENTS

INTRODUCTION

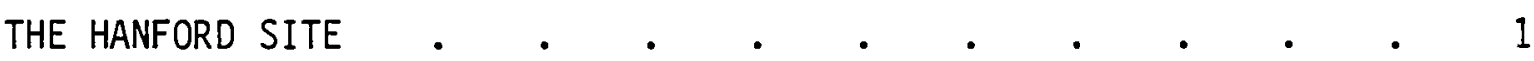

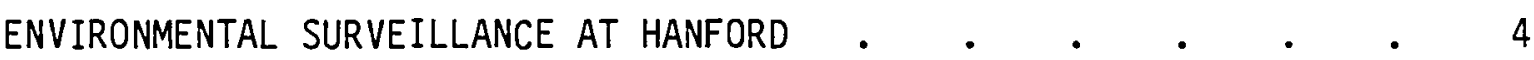

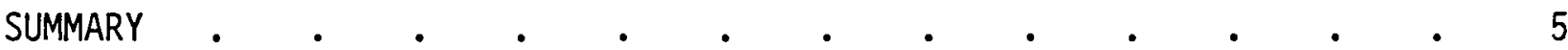

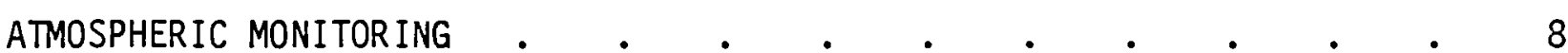

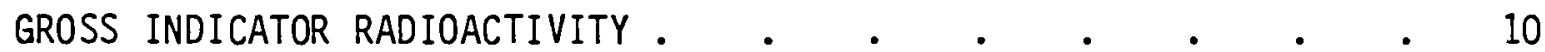

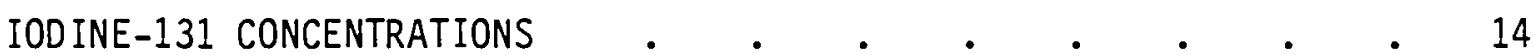

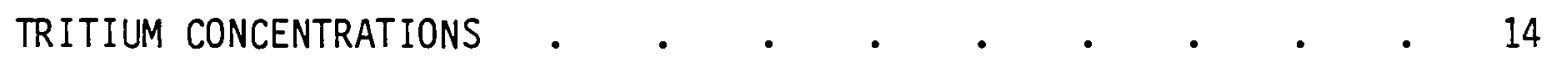

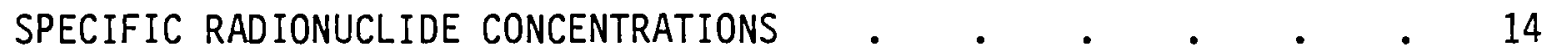

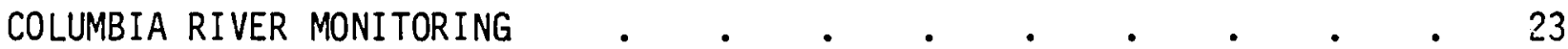

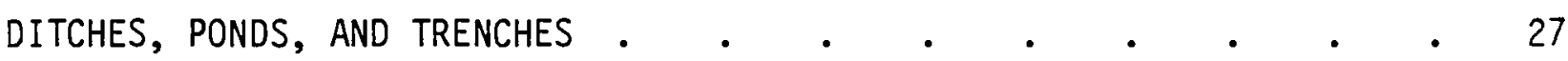

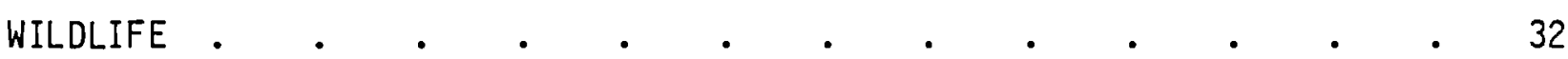

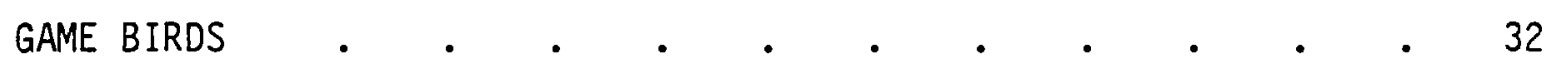

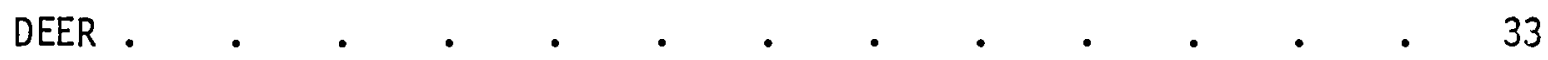

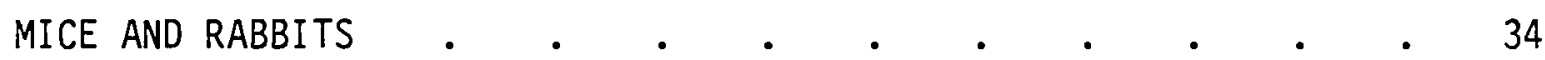

SOIL AND VEGETATION

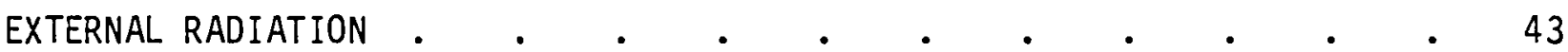

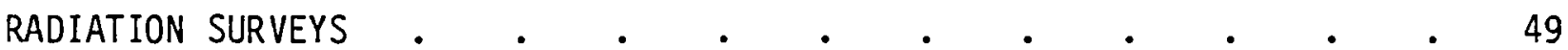

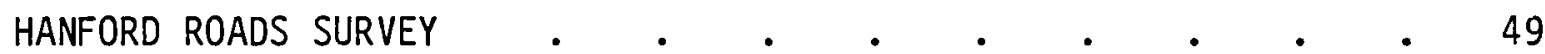

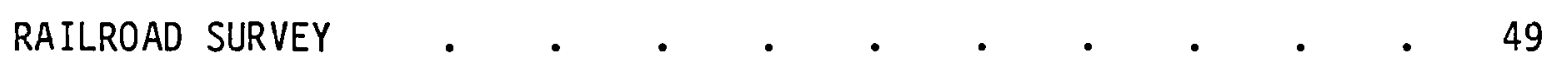

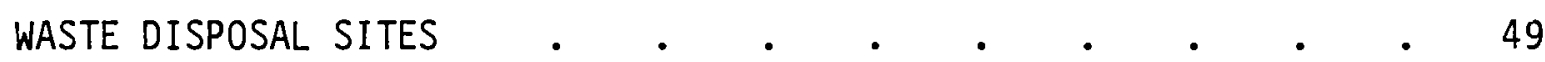

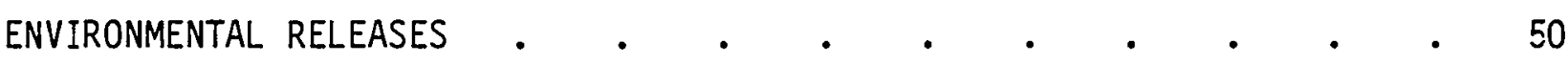

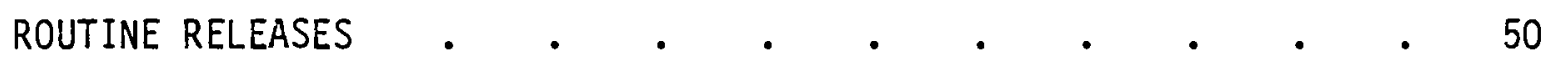




\begin{tabular}{|c|c|c|c|c|c|c|c|c|c|c|c|c|}
\hline & Gaseous Efflue & nts & - & - & - & • & • & - & - & • & • & 50 \\
\hline & Liquid Effluen & & $e^{\circ}$ & • & - & $\cdot$ & $\bullet^{\circ}$ & $e^{\circ}$ & ${ }^{\circ}$ & $\bullet$ & $\bullet$ & 51 \\
\hline & Solid Wastes & - & $\bullet$ & - & • & $\cdot$ & $\cdot$ & $\bullet$ & • & $\bullet$ & . & 55 \\
\hline ACC ID & ENTAL RELEASES & - & • & - & $\bullet$ & ${ }^{\circ}$ & $\cdot$ & • & • & $\bullet$ & 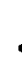 & 56 \\
\hline & Airborne Efflu & ents & • & $\bullet$ & $\bullet$ & 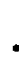 & $\bullet$ & $\cdot$ & $\bullet$ & $\bullet$ & 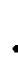 & 57 \\
\hline & Liquid Effluen & & 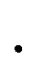 & $\bullet$ & • & ${ }^{\circ}$ & $\bullet$ & $\bullet$ & $\bullet$ & $\bullet$ & 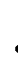 & 58 \\
\hline & Solid Wastes & - & - & $\cdot$ & $\bullet$ & ${ }^{\circ}$ & $\bullet$ & $\bullet$ & $\cdot$ & $\bullet$ & 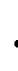 & 60 \\
\hline REFERENCES & - & $\cdot$ & $\bullet$ & $\bullet$ & $\bullet$ & 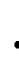 & $\bullet$ & $\bullet$ & • & $\bullet$ & 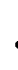 & 63 \\
\hline APPENDIX & - & - & $\bullet$ & • & • & . & • & • & • & • & 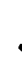 & A. 1 \\
\hline
\end{tabular}




\section{FIGURES}

1 DOE's Hanford Site in Washington State . . . . . . 2

2 Hanford Environmental Air-Sampling Locations During•1978 . . 8

3 Onsite and North Richland Air-Sampling Locations

During 1978

4 Monthly Average Gross Beta-Emitter Activity in the Atmosphere

5 Tritiated Water Vapor Concentrations During 1978 . . • 15

6 Radionuclide Concentrations in Air by Composite Group

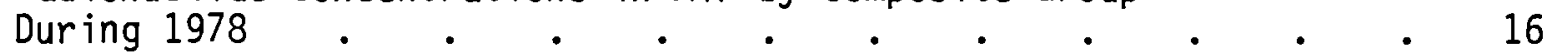

7 Radionuclide Concentrations in Columbia River Water During 1978 • . . . . • • • • . . 24

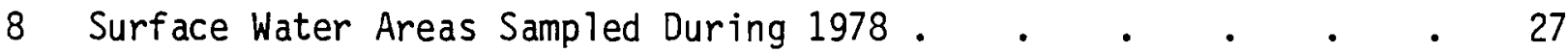

9 Total Alpha-Emitter Activities Observed in 200 Area Ponds During 1978 •

10 Total Beta-Emitter Activities Observed in 200 Area Ponds

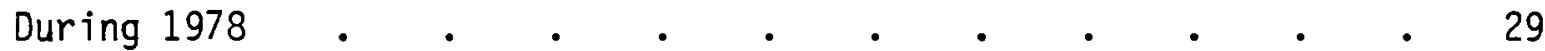

11 Strontium-90 Concentrations Observed in 200 Area Ponds

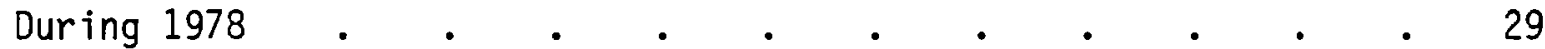

12 Soil and Vegetation Sampling Locations During 1978 • • • 37

13 Log-Normal Probability Plot of $90 \mathrm{Sr}$ in Soil and Vegetation . . . . . . . . . . 40

14 Log-Normal Probability Plot of ${ }^{137} \mathrm{Cs}$ in Soil and

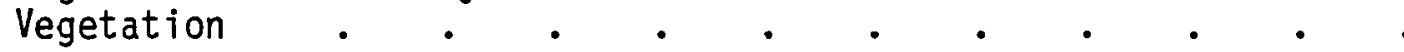

15 Log-Normal Probability Plot of 239-240 Pu in Soil and Vegetation

16 TLD External Dose Measurement Locations During 1978 . . . 43

17 Log-Normal Probability Plot of TLD External Dose Measurements

18 Locations of Immersion Dose Measurenents in the Columbia River During 1978 
19 Locations of External Dose Measurements Along the Columbia

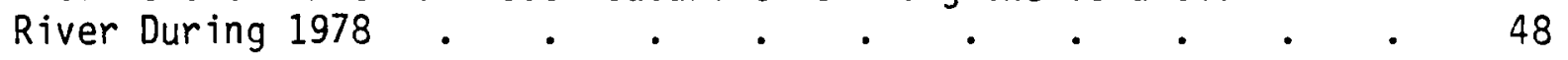

A.1 Sampling Locations in the 100-D Area . . . . . . A.1

A.2 Sampling Locations in the 100-K Area . . . . . . : A.1

A.3 Sampling Locations in the 100-N Area . . . . . . A.2

A.4 Sampling Locations in the 200 East Area . . . . . . A.2

A.5 Sampling Locations in the 200 West Area . . . . . . A.3

A.6 Sampling Locations in the 300 Area . . . . . . . A.3 


\section{TABLES}

1 Hanford Environmental Air Sampling Network for 1978 • • • . 11

2 Airborne Particulate Radioactivity During $1978 \quad$ • . . • . 13

3 Airborne Concentrations of Specific Radionuclides

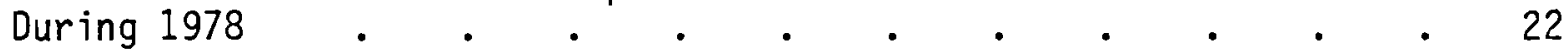

4 Radionuclide Concentrations in Surface Water Samples

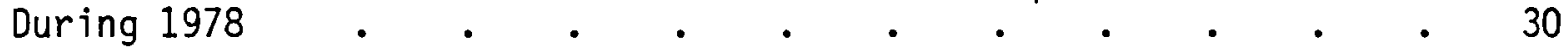

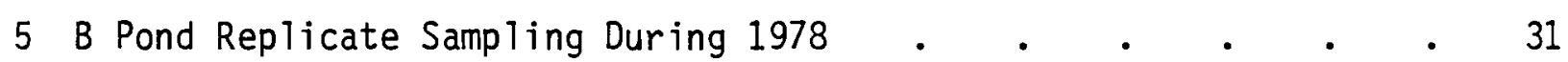

6 Radionuclide Concentrations in Game Bird Muscle Samples

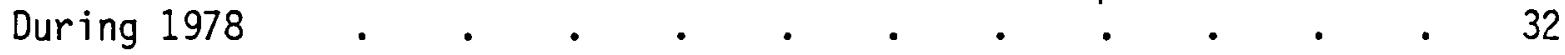

7 Radionuclide Concentrations in Deer Tissues During 1978 • • • 34

8 Radionuclide Concentrations in Rabbit Tissues During 1978 • • 35

9 Radionuclide Concentrations in Mice During 1978 . $\quad$ • . $\quad$ • 36

10 Concentrations of Artificially Produced Radionuclides

11 Concentrations of Artificially Produced Radionuclides

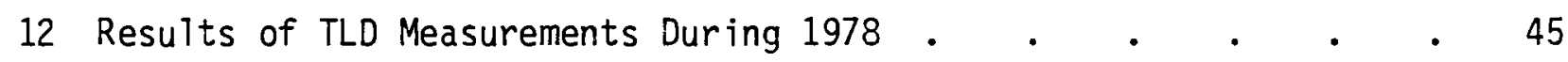

13 Columbia River Immersion Dose Rates During $1978 \quad$ • $\quad$ • $\quad$ • 47

14 Dose Rate Measurements Along the Columbia River Islands

15 Routine Radionuclide Releases to the River and the Atmosphere
During 1978 . $~ . ~$

\begin{tabular}{l} 
Nonradioactive Pollutants in Hanford Gaseous Effluents \\
During 1978 • \\
\hline
\end{tabular}

17 Hanford Solid Waste Effluents During $1978 \quad$ • $\quad$ • $\quad$ • $\quad$ • $\quad$ • 56 


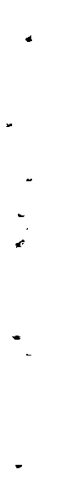




\section{$\underline{\text { INTRODUCTION }}$}

Department of Energy (DOE) operations at the Hanford Site over the past 35 years have encompassed a wide variety of nuclear and nonnuclear activities involving the production and use of radioactive and nonradioactive materials. During the course of these activities, materials have been released to the environment either during routine day-to-day operation or, from time to time, as a result of a process upset or other unplanned event. Effluent and environmental monitoring programs are conducted routinely to help assure that adequate controls of processes and effluent streams are maintained.

\section{THE HANFORD SITE}

The Hanford Site is located in a rural region of southeastern Washington State and occupies an area of $1500 \mathrm{~km}^{2}$ (570 square miles). The site, shown in Figure 1, lies about $320 \mathrm{~km}$ ( $200 \mathrm{mi}$ les) east of Portland, Oregon, $270 \mathrm{~km}$ (170 miles) southeast of Seattle, Washington, and $200 \mathrm{~km}$ (125 miles) southwest of Spokane, Washington. The Columbia River flows through the northern edge of the Hanford Site and forms part of its eastern boundary.

Established in 1943, the Hanford plant was originally designed, built, and operated to produce plutonium for nuclear weapons. At one time, nine production reactors were in operation, including eight with once-through cooling. Between December 1964 and January 1971, a11 eight reactors with once-through cooling were deactivated. $N$ Reactor, the remaining production reactor in operation, has a closed primary cooling loop. Steam from $N$ Reactor operation is used to drive turbine generators that produce up to 860 miliion watts of electrical power in the Washington Public Power Supply System's (WPPSS) Hanford Generating Plant. By the end of 1978, N Reactor had supplied enough steam to produce nearly 45 billion kilowatt-hours of electrical energy, which was fed to the Bonneville Power Administration grid covering the Pacific Northwest. 


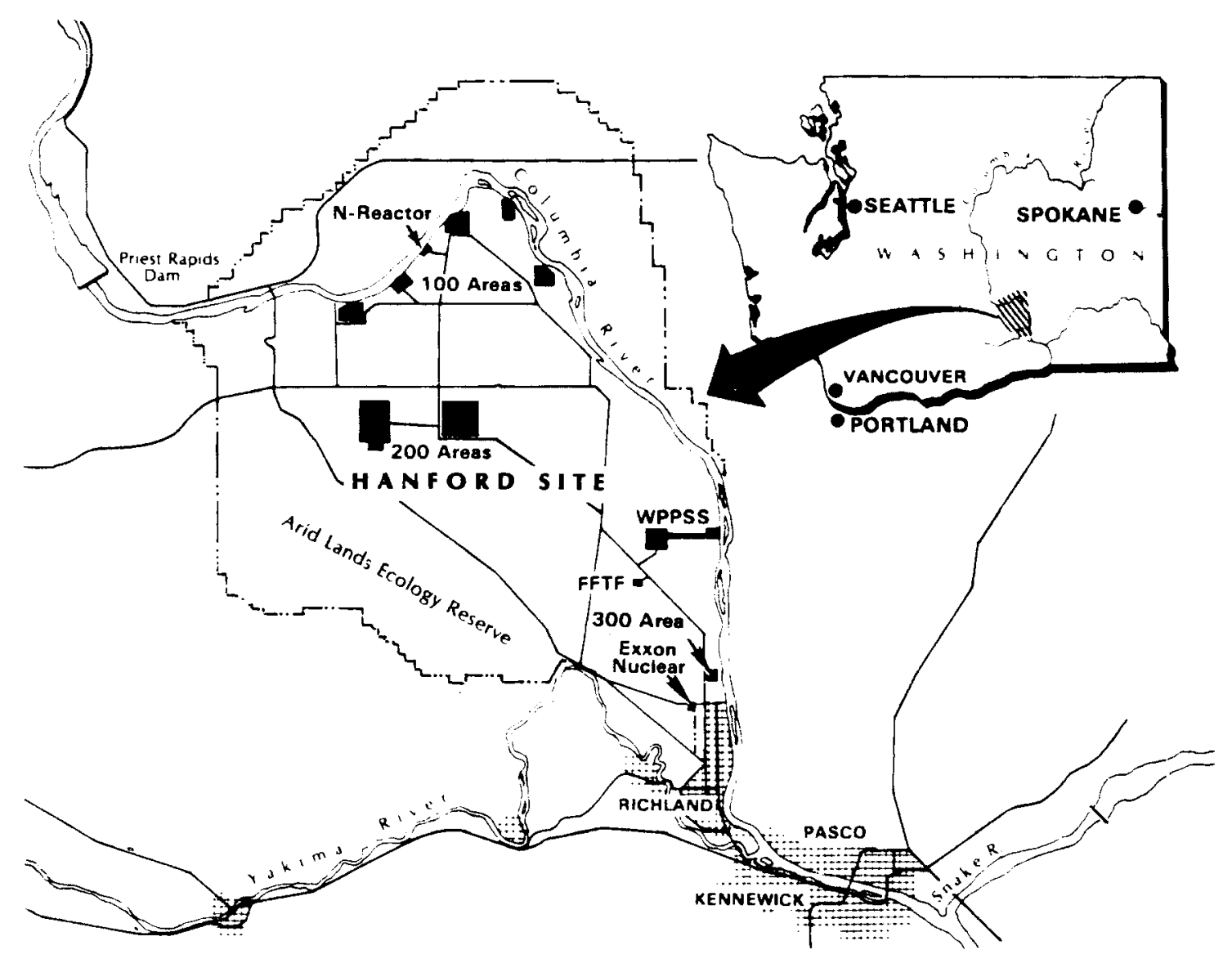

FIGURE 1. DOE's Hanford Site in Washington State

Facilities on the Hanford Site include the historic reactor facilities for plutonium production along the Columbia River, in what are known as the 100 Areas. The reactor fuel processing and waste management facilities are on a plateau about $11.3 \mathrm{~km}$ ( 7 miles) from the river in the 200 Areas. The 300 Area, just north of the city of Richland, contains the reactor fuel manufacturing facilities and research and development laboratories. The Fast Flux Test Facility (FFTF) is located in the 400 Area approximately $8.8 \mathrm{~km}$ (5.5 miles) northwest of the 300 Area.

Privately owned facilities within the Hanford Site boundaries include the WPPS generating station adjacent to $N$ Reactor, the WPPSS power reactor site and office buildings, and a radioactive waste burial site. The Exxon fuel fabrication facility is located immediately adjacent to the southern boundary of the Hanford Site. 
Principal DOE contractors operating at Hanford are:

- Rockwell Hanford Operations (RHO)--responsible for fuel processing, waste management, and all site support services such as plant security, fire protection, central stores, electrical power distribution, etc.

- Battelle Memorial Institute's Pacific Northwest Laboratories-responsible for operating the Pacific Northwest Laboratory (PNL), including research in the physical, life, and environmental sciences, environmental surveillance, and advanced methods of nuclear waste management.

- UNC Nuclear Industries (UNI)--responsible for operating and fabricating fue 1 for $N$ Reactor.

- Westinghouse Hanford Company (WHC)--responsible for operating the Hanford Engineering Development Laboratory (HEDL), including advanced reactor developments, principally the Liquid Metal Fast Breeder Reactor Program and the Fast Flux Test Facility.

During 1978, work at Hanford included N Reactor operation, nuclear fue 1 fabrication, liquid waste solidification, continued construction of the Fast Flux Test Facility, Hanford National Environmental Research Park (NERP) studies, and Arid Lands Ecology (ALE) studies, as well as continued use of a variety of research and laboratory facilities.

The desert plain on which Hanford is located has a sparse covering of vegetation primarily suited for grazing. The most broadly distributed type of vegetation on the site is the sagebrush/cheatgrass/bluegrass community. The mule deer is the most abundant big game mammal on the site while the most abundant small game animal is the cottontail rabbit. The raccoon is the most abundant furbearing animal. The osprey, golden eagle, and bald eagle are all occasional visitors to the relatively large areas of uninhabited land comprising the Hanford Site.

Hanford's climate is mild and dry; the area receives approximately $16 \mathrm{~cm}$ (6.3 in.) of precipitation annually. About $40 \%$ of the total precipitation 
occurs during November, December, and January, with only $10 \%$ falling in July, August, and September. The average maximum and minimum temperatures in July are $33^{\circ} \mathrm{C}\left(92^{\circ} \mathrm{F}\right)$ and $16^{\circ} \mathrm{C}\left(61^{\circ} \mathrm{F}\right)$. For January, the respective averages are $3^{\circ} \mathrm{C}$ $\left(37^{\circ} \mathrm{F}\right)$ and $-6^{\circ} \mathrm{C}\left(22^{\circ} \mathrm{F}\right)$. Approximately $45 \%$ of all precipitation from December through February is snow.

Mean monthly wind speeds range from about $14 \mathrm{~km} / \mathrm{hr}$ ( $9 \mathrm{mph}$ ) in the summer to $10 \mathrm{~km} / \mathrm{hr}(6 \mathrm{mph})$ in the winter. The prevailing regional winds are from the northwest, with strong drainage and crosswinds causing complicated surface flow patterns. The region is a typical desert area with frequent strong inversions that occur at night and break during the day, causing unstable and turbulent conditions.

\section{ENVIRONMENTAL SURVEILLANCE AT HANFORD}

The Hanford environmental surveillance program, conducted by Pacific Northwest Laboratory (PNL) under contract to DOE, provides for the measurement, interpretation, and evaluation of the radiological impact of Hanford operations on its onsite and offsite environs. The program is designed to evaluate all significant potential pathways for the release of radioactivity, especially those that may result in direct exposure of the public and those in which environmental reconcentration of radionuclides is likely to occur. Summaries and interpretations of the environmental measurements are published in several series of annual reports.

Presented in this report are the results of effluent and environmental monitoring and sampling conducted to determine the onsite impact of ongoing operations. (The previous report in this series, for 1977, is PNL-2677 (Houston and Blumer 1978)). Environmental data and analyses for offsite locations are presented in a separate report series, "Environmental Surveillance at Hanford" (Houston and Blumer 1979). Groundwater monitoring and evaluation are presented in a third report series, "Radiological Status of the Groundwater Beneath the Hanford Project" (Eddy 1979). 


\section{SUMMARY}

Continued compliance of Hanford operations with all applicable state and federal environmental regulations, with the exception of suspended particulates from several steam power plants, was demonstrated by the environmental and effluent data collected during 1978. Included in the environmental data collected were measurements of external radiation, and radionuclide analyses of air samples, Columbia River water, other surface waters, wildlife, soil, and vegetation. Periodically all roadways, railways, and active as well as retired waste disposal sites were surveyed to detect any abnormal levels of radioactivity. Highlights of the environmental status of the Hanford Site for 1978 follow:

- Average airborne concentrations of particulate alpha- and betaemitting radionuclides observed for all areas were essentially identical except in the 200 East Area. There, concentrations at the 200 ENC sampling station averaged $0.19 \times 10^{-12} \mu \mathrm{Ci} / \mathrm{ml}$, wel1 within the most restrictive Concentrations Guides in Manual Chapter 0524, Appendix, Annex A, Table II, Column 1 (U.S. Energy Research and Development Administration 1973) but significantly higher than concentrations at all other sampling stations. Several times during the year, concentrations of ${ }^{137} \mathrm{Cs}$ in the 200 East Area were also higher than those measured in other areas. Hanford operations in the 200 East Area were responsible for these slightly higher ${ }^{137} \mathrm{Cs}$ concentrations, but onsite impact was limited to the immediate area. Concentrations of all other radionuclides were similar at all stations, implying no detectable impact from Hanford operations.

- The impact of Hanford operations on radionuclide levels in Columbia River water was very smal1. Throughout $1978,{ }^{60} \mathrm{Co}$ and ${ }^{129}$ I were the only radionuclides observed at higher concentrations downstream than upstream. Small quantities of these radionuclides routinely reach the river as a result of current and past Hanford operations. 
The highest levels of all radionuclides in the river were far less than $1 \%$ of the most restrictive Concentration Guides in Manual Chapter 0524 Appendix.

- Radionuclide concentrations in open surface waters on the Hanford. Site during 1978 were within the expected range and were typical of the concentrations observed in recent years. With the exception of West Lake, these ponds, swamps, and ditches receive liquid effluents from Hanford facilities that may contain low concentrations of radionuclides.

- Wildlife samples (i.e., game birds, deer, rabbits, and mice) were taken on the Hanford Site. Analyses of these samples indicated that very small quantities of radionuclides related to Hanford operations are available in certain areas. Samples obtained near surface waters and certain other waste sites contained low concentrations of several radionuclides $\left({ }^{90} \mathrm{Sr},{ }^{137} \mathrm{Cs}\right.$, and $\left.{ }^{239} \mathrm{Pu}\right)$. Concentrations of certain radionuclides in waterfowl, deer, and rabbits were slightly lower than in previous years, possibly indicating the reduced availability of these radionuclides in the food chain. The potential total-body dose to an individual consumming $454 \mathrm{~g}$ (1 l lb) of duck meat or about $23 \mathrm{~kg}(50 \mathrm{lb})$ of deer meat containing the maximum amounts of radionuclides observed in 1978 samples would be about 4 mrem from the duck meat or less than 1 mrem from the deer meat.

- In general, radionuclide concentrations in soil and vegetation samples were similar at both onsite and offsite locations. Samples at a few sites, primarily in the vicinity of the 200 Areas, contained concentrations of ${ }^{90} \mathrm{Sr},{ }^{137} \mathrm{Cs}$, and ${ }^{239-240} \mathrm{Pu}$ at levels above those attributable to worldwide fallout. The unusual radionuclide concentrations observed in a few soil and vegetation samples at onsite locations other than the 200 Areas are unsupported by other data and are considered spurious results at this time. 
- External radiation dose rates measured at inner sector and outer sector stations were indistinguishable from each other, indicating no offsite impact. Higher dose rates were measured only in the vicinity of the $100-\mathrm{N}$ and 200 Areas. During 1978, the average background dose from all sources in the Hanford environs was about 100 mrem.

- The external radiation dose rates measured at several locations along the Columbia River islands and shoreline were higher than those measured at other locations. Residual ${ }^{60}$ Co from past operation of the once-through-cooled production reactors, present in the sediment along the river, was responsible for these elevated dose rates. At the 100-N trench springs, an external dose rate of about 10 times the average Hanford background dose rate exists because of the slightly contaminated water seeping from the ground.

- Surveys of Hanford Site roadways, railways, and waste disposal sites disclosed only minor problems at a few waste disposal sites.

- Routine releases of radionuclides to the environment from day-to-day operations during 1978 were about the same as those measured in recent years.

- During 1978, 14 unusual occurrences on the Hanford Site led to accidental releases of effluents to the environment. None of these occurrences, however, resulted in any significant impact on the environment. Three of the occurrences resulted in small airborne releases of radioactive material, three in the release of excessively hot water to the Columbia River, four in the discharge of radioactively contaminated liquid to the soil, and four in the release of solid waste to the soil. Two of the releases to soil involved isolated instances of radioactive contamination of and by wildlife. The quantities of radionuclides released to the environs as a result of these occurrences were far less than those associated with routine releases. 


\section{ATMOSPHERIC MONITORING}

During 1978, air samples were taken at 44 locations both on- and offsite as shown in Figures 2 and 3. (Detailed maps showing specific locations of the sampling stations around the operating areas are contained in the Appendix.) Each air sampler draws air at a flow rate of $2.5 \mathrm{~m}^{3} / \mathrm{hr}\left(1.5 \mathrm{ft}^{3} / \mathrm{min}\right)$ through a high-efficiency particulate filter and a $5.5-\mathrm{cm}-10 n$ by $4.4-\mathrm{cm}-$ diameter (2-in. by 1.5-in.) charcoal cartridge for the collection of gaseous radioiodine. The particulate filters were collected biweekly and analyzed for total alpha and total beta activity after a delay of 7 days to allow the shortlived radon and thoron daughters to decay. Once a month, the particulate

FIGURE 2. Hanford Environmental Air-Sampling Locations During 1978

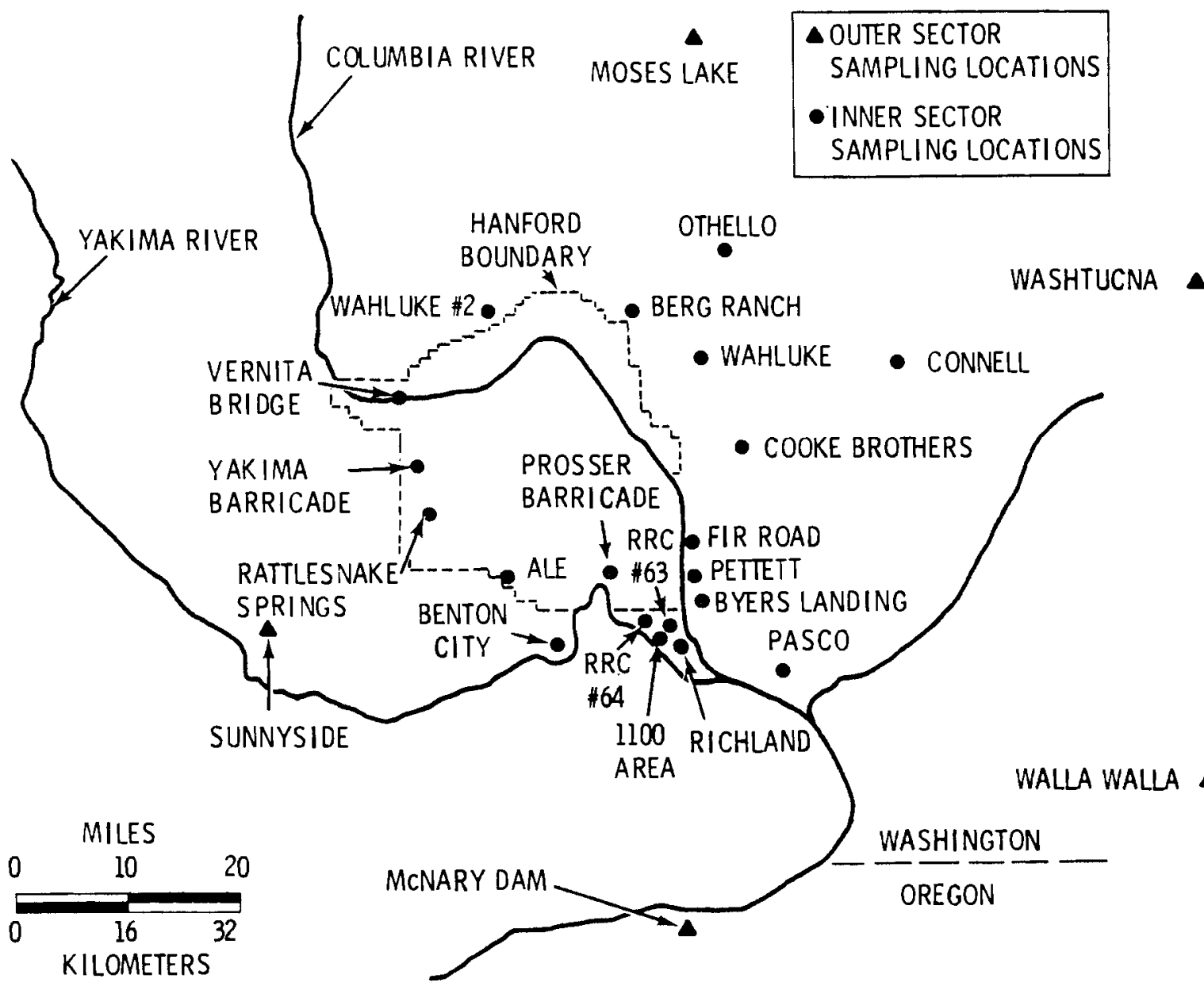




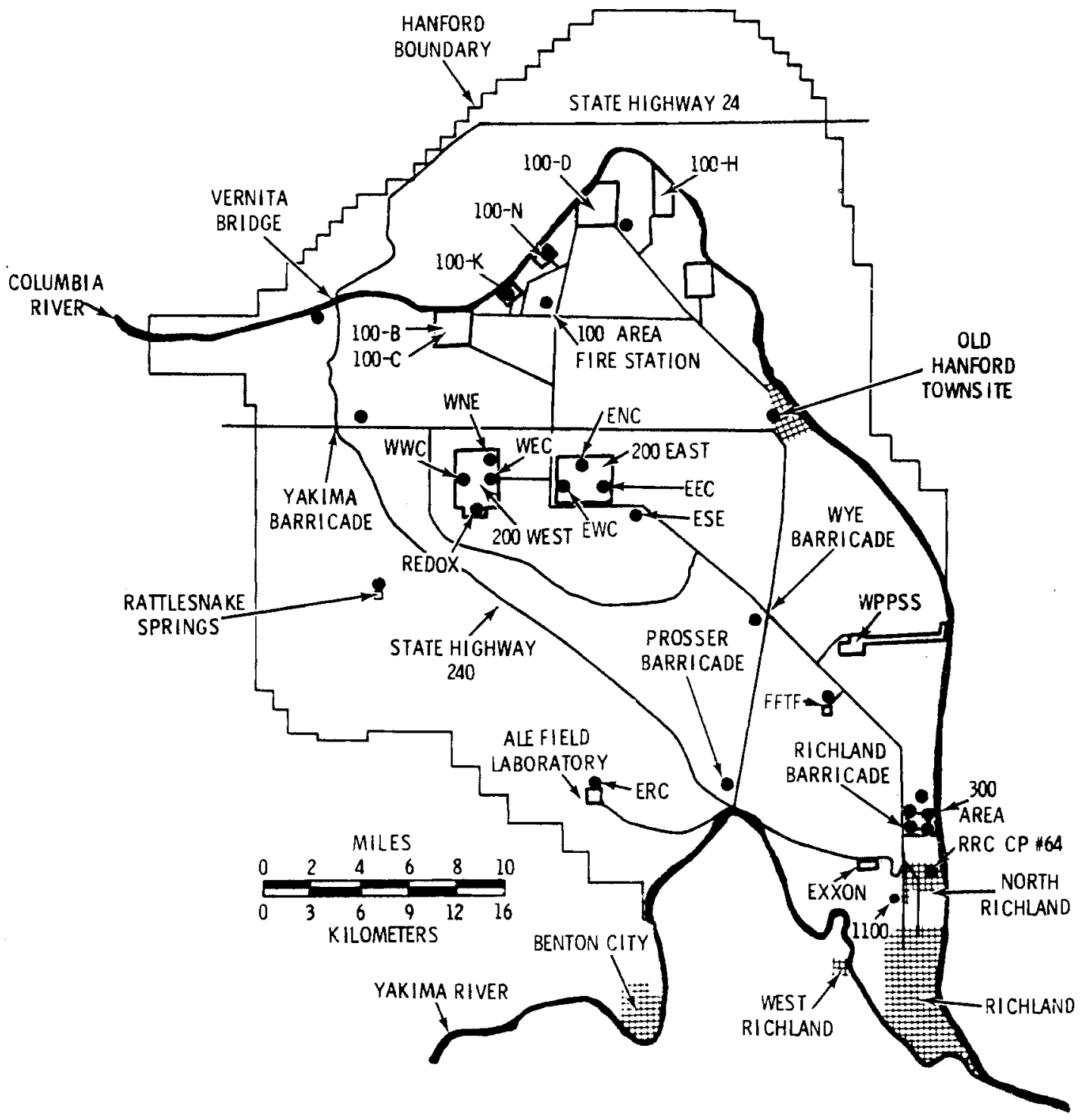

FIGURE 3. Onsite and North Richland Air-Sampling Locations During 1978

filters were grouped into geographical composites $(a)$ and analyzed by gamma spectrometry. On a quarterly frequency, the accumulated particulate filters from each geographical location were dissolved and analyzed for ${ }^{90} \mathrm{Sr}$ and

(a) The composites are made up of samples grouped by operating areas, sectors of an inner circle that approximates the Hanford Site boundary, and sectors of an outer circle that is considerably removed from the site boundary. 
plutonium. Charcoal cartridges from 10 of the sampling stations were collected and analyzed biweekly for ${ }^{131}$ I. The charcoal cartridges at the remaining 34 stations were collected monthly but not analyzed; these samples are analyzed only if one or more of the results from the biweekly analyses exceed the detection limit.

At five sampling locations, a small portion of the air is bled off after going through the particulate filter and is then drawn through a cartridge of indicating silica gel at a rate of $470 \mathrm{~cm}^{3} / \mathrm{min}\left(1 \mathrm{ft}^{3} / \mathrm{hr}\right)$. These transparent cartridges, $25 \mathrm{~cm}$ in length by $5 \mathrm{~cm}$ in diameter (10 in. by 2 in.), are used to collect airborne water vapor during the biweekly sampling periods. Water collected by the silica gel is driven off and analyzed for tritium (HTO).

The frequency of sample collection at each air sampling station and the location of and composite group for each station are shown in Table 1.

\section{GROSS INDICATOR RADIOACTIVITY}

Total alpha and total beta analyses of particulate air filters provide a relatively rapid and sensitive indication of the gross airborne radionuclide concentrations in the Hanford environs. Shown in Figure 4 are the temporal patterns of total beta-emitter activity in air for the years 1974 through 1978. In this figure, concentrations of beta-emitting radionuclides at the inner northeast and inner southeast sector stations (usually downwind from Hanford) are compared with all operating area stations and the distant or outer stations. The outer stations are sufficiently remote from Hanford operations that the observed concentrations can be assumed to be due to natural radioactivity or to worldwide fallout. During 1978, the maximum concentrations of airborne beta-emitting radionuclides were observed during the spring months immediately following a nuclear test by the People's Republic of China on March 15, 1978. Concentrations were above normal ambient levels at all stations during this period. A second Chinese nuclear test on December 14, 1978, produced no measurable increase in airborne radionuclide concentrations. 
TABLE 1. Hanford Environmental Air Sampling Network for 1978

$\frac{\text { Composite Group }}{100 \text { Areas }} \quad \frac{\text { Location (b) }}{} \begin{aligned} & 100-K \\ & 100-N \\ & 100-D \\ & 100 \text { Area Fire Station }\end{aligned}$

\begin{tabular}{|c|c|c|}
\hline \multicolumn{3}{|c|}{ Sampling Frequency (a) } \\
\hline $\begin{array}{c}\text { Particulate } \\
\text { Filter }\end{array}$ & $\begin{array}{l}\text { Charcoal } \\
\text { Cartridge }\end{array}$ & $\begin{array}{l}\text { Silica Gel } \\
\text { Cartridge }\end{array}$ \\
\hline $\begin{array}{l}B W \\
B W \\
B W \\
3 W\end{array}$ & $\begin{array}{l}M \text { (NRA) } \\
M \text { (NRA) } \\
B W \\
M \text { (NRA) }\end{array}$ & $B W$ \\
\hline
\end{tabular}

200 East Area

200 ENC
200 EEC
200 ESE
200 EWC

$\begin{array}{ll}B W & M \text { (NRA) } \\ B W & M \text { (NRA) } \\ B W & B W \text { (NRA) } \\ B W & M \text { (NRA) }\end{array}$

200 West Area

$$
\begin{aligned}
& 200 \text { WNE } \\
& 200 \text { WEC } \\
& \text { Redox } \\
& 200 \text { WWC }
\end{aligned}
$$

$\begin{array}{ll}B W & M(N R A) \\ B W & M(N R A) \\ B W & M(N R A) \\ B W & M(N R A)\end{array}$

300 Area

$$
\begin{aligned}
& 300 \text { Pond } \\
& 3614-A \text { Bldg. } \\
& 300 \text { South Gate } \\
& 300 \text { SW Gate } \\
& 3705 \text { B1dg. }
\end{aligned}
$$

$\begin{array}{ll}B W & M \text { (NRA) } \\ B W & M \text { (NRA) } \\ B W & M \text { (NRA) } \\ \text { BW } & B W \text { (NRA) } \\ B W & M \text { (NRA }\end{array}$

Inner Northeast Sector

$$
\begin{aligned}
& \text { Berg Ranch } \\
& \text { Wahluke Watermaster } \\
& \text { Cooke Brothers } \\
& \text { Othello }
\end{aligned}
$$

$\begin{array}{ll}B W & M \text { (NRA) } \\ B W & M \text { (NRA) } \\ B W & M \text { (NRA) } \\ \text { BW } & M \text { (NRA) } \\ \text { BW } & M \text { (NRA) }\end{array}$

Inner East Sector

$$
\begin{aligned}
& \text { Hanford } \\
& \text { Wye Barricade } \\
& \text { FFTF }
\end{aligned}
$$

$\begin{array}{ll}B W & M(N R A) \\ B W & M(N R A) \\ B W & B W\end{array}$

Inner Southeast Sector

Fir Road

Pettett

Byers Landing

Pasco

CP $\$ 64$

1100 Area

Richland

$\begin{array}{ll}B W & B W \\ B W & B W \\ B W & B W(\text { NRA) } \\ B W & M \text { (NRA) } \\ B W & M \text { (NRA) } \\ B W & B W\end{array}$

Prosser Barricade Benton City

ALE Fieid Lab

Rattlesnake Springs

$\begin{array}{ll}B W & M \text { (NRA) } \\ B W & B W \text { (NRA) } \\ B W & M \text { (NRA) } \\ B W & M \text { (NRA) } \\ \text { BW } & M \text { (NRA) } \\ B W & M \text { (NRA) } \\ \text { BW } & \end{array}$

Outer Northeast Sector

Vernita

Yakima Barricade

Wahluke $\# 2$

$M$ (NRA)

$\begin{array}{lll}\text { Moses Lake } & \text { BW } & M \text { (NRA) } \\ \text { Washtucna } & B W & M \text { (NRA) }\end{array}$

Outer Southeast Sector

$$
\begin{aligned}
& \text { Walla Walla } \\
& \text { McNary }
\end{aligned}
$$$$
\text { BW M M NRA) }
$$

Outer West Sector$$
\text { BW } M \text { (NRA) }
$$

(a) BW - biweekly. M - monthly. NRA - not routine 'y analyzed.

(b) Location: FFTF - Fast Flux Test Facility. ALE - Arid Lands Ecology. 


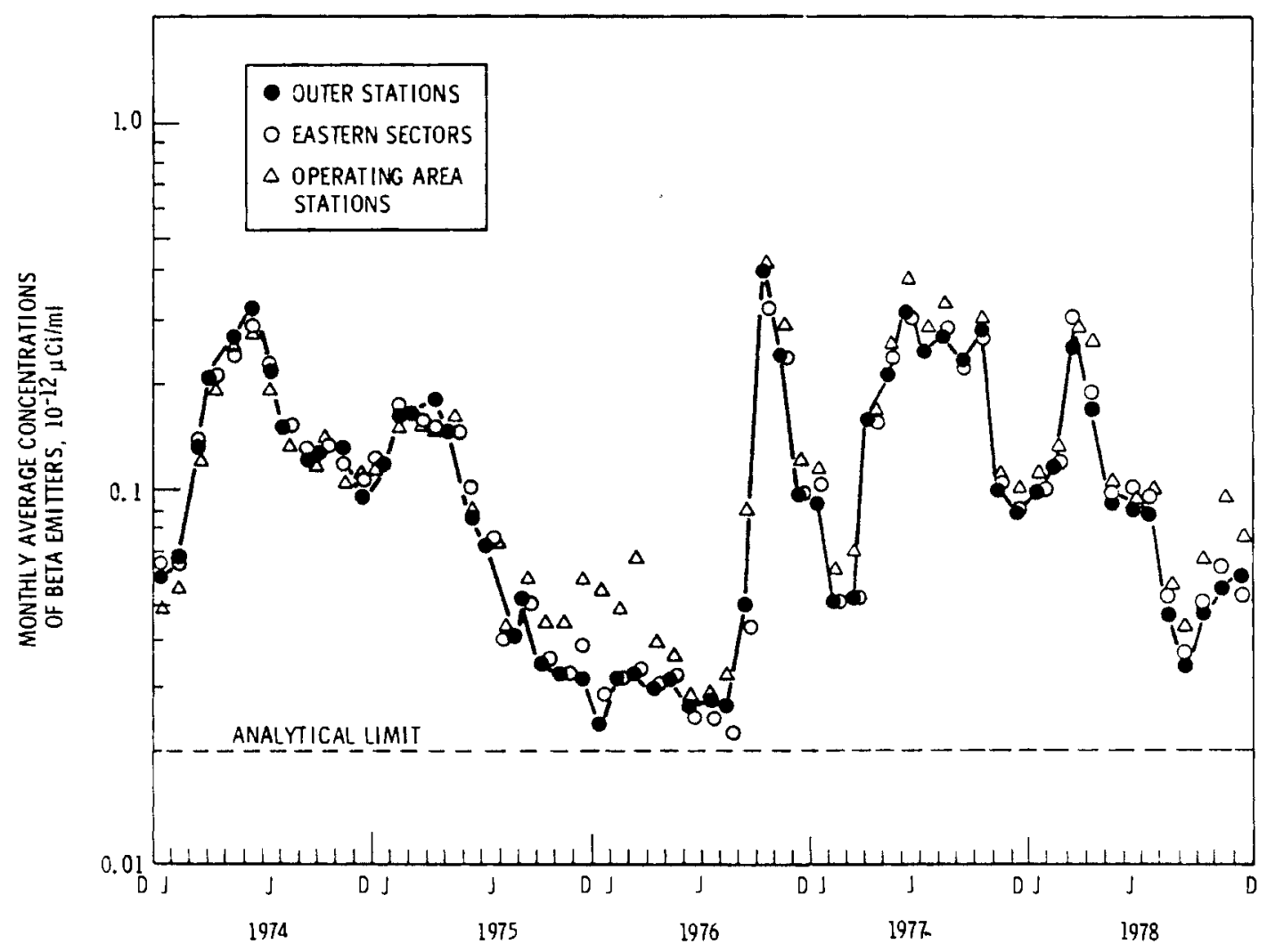

FIGURE 4. Monthly Average Gross Beta-Emitter Activity in the Atmosphere

Shown in Table 2 are the results of total beta and total alpha analyses taken at all sampling locations during 1978. The average beta-emitter concentration for the outer stations was $0.10 \times 10^{-12} \mu \mathrm{Ci} / \mathrm{ml}$. That of the inner stations was essentially the same at $0.11 \times 10^{-12} \mu \mathrm{Ci} / \mathrm{mr}$. At only one sampling station in the operating areas (200 ENC) was the air concentration substantially greater $\left(0.19 \times 10^{-12} \mu \mathrm{Ci} / \mathrm{ml}\right)$ than the normal ambient levels. This value is insignificant when compared with the Concentration Guides; however, it does indicate that a source of airborne radionuclides probably exists near this sampling station.

Analysis for alpha-emitting radionuclides was performed on filters obtained from 14 of the 44 sampling stations. The results were similar at all locations and are attributed to worldwide fallout and naturally occurring radionuclides in the air. 
TABLE 2. Airborne Particulate Radioactivity During 1978

\begin{tabular}{|c|c|c|c|c|c|c|c|c|c|}
\hline \multirow[b]{3}{*}{ Composite Group } & \multirow[b]{3}{*}{ Location (c) } & \multicolumn{8}{|c|}{ Concentration, $10^{-12} \mathrm{yCi} / \mathrm{ml}(\mathrm{a})$} \\
\hline & & \multicolumn{4}{|c|}{ Total Beta } & \multicolumn{4}{|c|}{ Total Alpha $(b)$} \\
\hline & & $\begin{array}{l}\text { No. of } \\
\text { Samples }\end{array}$ & Maximun & Minimum & $\begin{array}{l}\text { Annual } \\
\text { Average }(d) \\
\end{array}$ & $\begin{array}{l}\text { No. of } \\
\text { Samples }\end{array}$ & Maximum & Minimum & $\begin{array}{l}\text { Annual }(\mathrm{d}) \\
\text { Aver age }\end{array}$ \\
\hline 100 Areas & $\begin{array}{l}100-K \\
100-N \\
100-0 \\
100 \text { Area Fire Station }\end{array}$ & $\begin{array}{l}25 \\
27 \\
26 \\
26\end{array}$ & $\begin{array}{l}0.52 \\
0.35 \\
0.26 \\
0.54\end{array}$ & $\begin{array}{l}0.02 \\
0.03 \\
0.02 \\
0.03\end{array}$ & $\begin{array}{l}0.11 \\
0.10 \\
0.09 \\
0.12 \\
0.11\end{array}$ & $\begin{array}{l}0 \\
0 \\
0 \\
0\end{array}$ & 。 & & \\
\hline 200 East Ared & $\begin{array}{l}200 \mathrm{ENC} \\
200 \mathrm{EEC} \\
200 \mathrm{ESE} \\
200 \mathrm{EHC}\end{array}$ & $\begin{array}{l}28 \\
27 \\
25 \\
27\end{array}$ & $\begin{array}{l}1.1 \\
0.55 \\
0.48 \\
0.55\end{array}$ & $\begin{array}{l}0.03 \\
0.03 \\
0.03 \\
0.03\end{array}$ & $\begin{array}{l}0.19 \\
0.13 \\
0.10 \\
0.12 \\
0.14\end{array}$ & $\begin{array}{r}27 \\
27 \\
24 \\
0\end{array}$ & $\begin{array}{l}0.004 \\
0.002 \\
0.002\end{array}$ & $\begin{array}{l}0.0007 \\
0.0006 \\
*\end{array}$ & $\begin{array}{r}0.001 \\
0.001 \\
<0.001 \\
\\
<0.001\end{array}$ \\
\hline 200 Hest Area & $\begin{array}{l}200 \text { WHE } \\
200 \text { WEC } \\
\text { Redox } \\
200 \text { WHC }\end{array}$ & $\begin{array}{l}25 \\
24 \\
27 \\
26\end{array}$ & $\begin{array}{l}0.65 \\
0.59 \\
0.67 \\
0.39\end{array}$ & $\begin{array}{l}0.02 \\
0.02 \\
0.03 \\
0.04\end{array}$ & $\begin{array}{l}0.11 \\
0.11 \\
0.12 \\
0.10 \\
0.11\end{array}$ & $\begin{array}{r}0 \\
24 \\
27 \\
0\end{array}$ & $\begin{array}{l}0.002 \\
0.002\end{array}$ & 0.0005 & $\begin{array}{r}<0.001 \\
0.001 \\
<0.001\end{array}$ \\
\hline 300 Area & $\begin{array}{l}300 \text { Pond } \\
3614-A \text { 8ldg. } \\
300 \text { South Gate } \\
300 \text { SW Gate } \\
3705 \text { Bldg. }\end{array}$ & $\begin{array}{l}26 \\
25 \\
26 \\
27 \\
27\end{array}$ & $\begin{array}{l}0.47 \\
0.46 \\
0.45 \\
0.48 \\
0.39\end{array}$ & $\begin{array}{l}0.03 \\
0.04 \\
0.03 \\
0.03 \\
0.03\end{array}$ & $\begin{array}{l}0.11 \\
0.12 \\
0.12 \\
0.11 \\
0.11 \\
0.11\end{array}$ & $\begin{array}{r}0 \\
0 \\
26 \\
0 \\
0\end{array}$ & 0.003 & 0.0007 & 0.001 \\
\hline Inner Mortheast Sector & $\begin{array}{l}\text { 3erg Ranch } \\
\text { wahluke Watermaster } \\
\text { cooke Brothers } \\
\text { Othe } 110 \\
\text { Conneli }\end{array}$ & $\begin{array}{l}26 \\
25 \\
24 \\
25 \\
25\end{array}$ & $\begin{array}{l}0.42 \\
0.33 \\
0.43 \\
0.44 \\
0.56\end{array}$ & $\begin{array}{l}0.03 \\
0.03 \\
0.03 \\
0.04 \\
0.03\end{array}$ & $\begin{array}{l}0.12 \\
0.10 \\
0.10 \\
0.11 \\
0.12 \\
0.11\end{array}$ & $\begin{array}{r}26 \\
0 \\
0 \\
0\end{array}$ & 0.003 & 0.0006 & 0.001 \\
\hline Inner East Sector & $\begin{array}{l}\text { Hanford } \\
\text { Hye garric ade } \\
\text { FFTF }\end{array}$ & $\begin{array}{l}27 \\
26 \\
22\end{array}$ & $\begin{array}{l}0.47 \\
0.76 \\
0.47\end{array}$ & $\begin{array}{l}0.03 \\
0.04 \\
0.03\end{array}$ & $\begin{array}{l}0.11 \\
0.13 \\
0.13 \\
0.12\end{array}$ & $\begin{array}{r}0 \\
26 \\
22\end{array}$ & $\begin{array}{l}0.003 \\
0.003\end{array}$ & $\begin{array}{l}0.0006 \\
0.0008\end{array}$ & $\begin{array}{l}0.001 \\
\frac{0.001}{0.001}\end{array}$ \\
\hline Inner Southeast Sector & $\begin{array}{l}\text { Fir Road } \\
\text { Pettett } \\
\text { Byers Landing } \\
\text { Pasco } \\
\text { CP \$64 } \\
\text { I100 Area } \\
\text { Rich land }\end{array}$ & $\begin{array}{l}21 \\
25 \\
25 \\
24 \\
26 \\
26 \\
23\end{array}$ & $\begin{array}{l}0.25 \\
0.54 \\
0.49 \\
0.48 \\
0.46 \\
0.49 \\
0.37\end{array}$ & $\begin{array}{l}0.03 \\
0.03 \\
0.02 \\
0.02 \\
0.04 \\
0.04 \\
0.03\end{array}$ & $\begin{array}{l}0.10 \\
0.11 \\
0.10 \\
0.11 \\
0.11 \\
0.10 \\
\frac{0.09}{0.10}\end{array}$ & $\begin{array}{r}0 \\
0 \\
25 \\
y \\
26 \\
0 \\
0 \\
23\end{array}$ & $\begin{array}{l}0.002 \\
0.003 \\
0.002\end{array}$ & $\begin{array}{c}0.0007 \\
0.0003 \\
\end{array}$ & $\begin{array}{r}0.001 \\
0.001 \\
<0.001 \\
<0.001\end{array}$ \\
\hline Inner Southest Sector & $\begin{array}{l}\text { Prosser Barricade } \\
\text { Benton City } \\
\text { ALE F Field Lab } \\
\text { Rattlesnake Springs }\end{array}$ & $\begin{array}{l}26 \\
23 \\
26 \\
26\end{array}$ & $\begin{array}{l}0.55 \\
0.49 \\
0.62 \\
0.60\end{array}$ & $\begin{array}{l}0.04 \\
0.02 \\
0.03 \\
0.03\end{array}$ & $\begin{array}{l}0.12 \\
0.10 \\
0.11 \\
0.12 \\
0.11\end{array}$ & $\begin{array}{r}26 \\
23 \\
0 \\
0\end{array}$ & $\begin{array}{l}0.003 \\
0.003\end{array}$ & $\stackrel{0.0006}{\star}$ & $\begin{array}{r}0.001 \\
<0.001 \\
\\
<0.001\end{array}$ \\
\hline Inner Horthest Sector & $\begin{array}{l}\text { Vernita } \\
\text { Yak ina Barricade } \\
\text { Wahluke } \$ 2\end{array}$ & $\begin{array}{l}25 \\
25 \\
25\end{array}$ & $\begin{array}{l}0.30 \\
0.65 \\
0.34\end{array}$ & $\begin{array}{l}0.03 \\
0.03 \\
0.03\end{array}$ & $\begin{array}{l}0.09 \\
0.10 \\
0.11 \\
0.10\end{array}$ & $\begin{array}{l}0 \\
0 \\
0\end{array}$ & & & \\
\hline Outer Northeast Sector & $\begin{array}{l}\text { Moses Lake } \\
\text { Washtuena }\end{array}$ & $\begin{array}{l}24 \\
22\end{array}$ & $\begin{array}{l}0.20 \\
0.65\end{array}$ & $\begin{array}{l}0.03 \\
0.01\end{array}$ & $\begin{array}{l}0.09 \\
\frac{0.12}{0.11}\end{array}$ & $\begin{array}{l}0 \\
0\end{array}$ & & & \\
\hline Outer Southeast Sector & $\begin{array}{l}\text { Halla Walla } \\
\text { Mchary }\end{array}$ & $\begin{array}{l}26 \\
26\end{array}$ & $\begin{array}{l}0.46 \\
0.20\end{array}$ & $\begin{array}{l}0.04 \\
0.03\end{array}$ & $\begin{array}{l}0.11 \\
0.08 \\
0.10\end{array}$ & $\begin{array}{l}0 \\
0\end{array}$ & & & \\
\hline Outer west Sector & Sunnys ide & 23 & 0.27 & 0.03 & 0.09 & 0 & & & \\
\hline Detection Limit & & & & & 0.005 & & & & 0.0003 \\
\hline Concentration Guide (e) & & & & & 100 & & & & 0.02 \\
\hline
\end{tabular}

Less than detection 1 init.

(b) Total aipha activity does not include any significant contribution from naturally occurring radon daghters in the air. The filters are held 7 days before analysis to allow decay of these radionuclides.

(c) Location: FFTF - Fast Flux Test Facility. ALE - Arid Lands Ecology.

(d) A "less-than" value is shown in cases where one or more analytical results were less than the detection limit. The detection limit value

(e) Was used in place of the actual analytical result in computing the average for these cases.

Manual Chapter 0524 Appendix standards ajpiy to concentrations of radioactivity in excess of those due to naturally occurring or worlaride fallout radioactivity. 


\section{IODINE-131 CONCENTRATIONS}

During 1978, biweekly analysis for ${ }^{131}$ I in the atmosphere was performed on samples obtained from 10 sampling stations; samplers at the other stations were changed monthly but not analyzed; the samples that were collected were available for analysis in case of any indication that iodine of Hanford origin was present in the atmosphere. Concentrations of ${ }^{131}$ I in the air were all below the detection 1 imit during 1978 except during a 1-month period following the Chinese nuclear test in March when some small positive values were observed. Daily average concentrations as high as $0.086 \times 10^{-12} \mu \mathrm{Ci} / \mathrm{ml}$ were observed during special fallout monitoring. Longer term (2-week) average concentrations observed in routine samples during the fallout period were as high as $0.035 \times 10^{-12} \mu \mathrm{Ci} / \mathrm{ml}$.

\section{TRITIUM CONCENTRATIONS}

Airborne water vapor was sampled at two operating areas and at three inner sector stations during 1978. Analytical results for the biweekly samples are shown in Figure 5 . The small randomly varying concentrations observed at all stations are attributed to worldwide fallout. During 1978, the average concentration of tritiated water vapor in the air was $1 \times 10^{-12} \mu \mathrm{Ci} / \mathrm{ml}$, less than $0.001 \%$ of the most restrictive Concentration Guide.

\section{SPECIFIC RADIONUCLIDE CONCENTRATIONS}

Figure 6 shows the results of specific radionuclide analyses of each of the 12 composite groups shown in Table 1. These analyses were done monthly $\left({ }^{95} \mathrm{ZrNb},{ }^{106} \mathrm{Ru},{ }^{137} \mathrm{Cs}\right.$, and $\left.{ }^{144} \mathrm{CePr}\right)$ and quarterly $\left({ }^{90} \mathrm{Sr}\right.$ and Pu-total). All of the radionuclides shown result from worldwide fallout and, potentially, from Hanford operations. Comparison of the concentrations observed at stations near the operations areas with those observed at more distant stations reveals whether the concentrations are attributable to Hanford operations. 


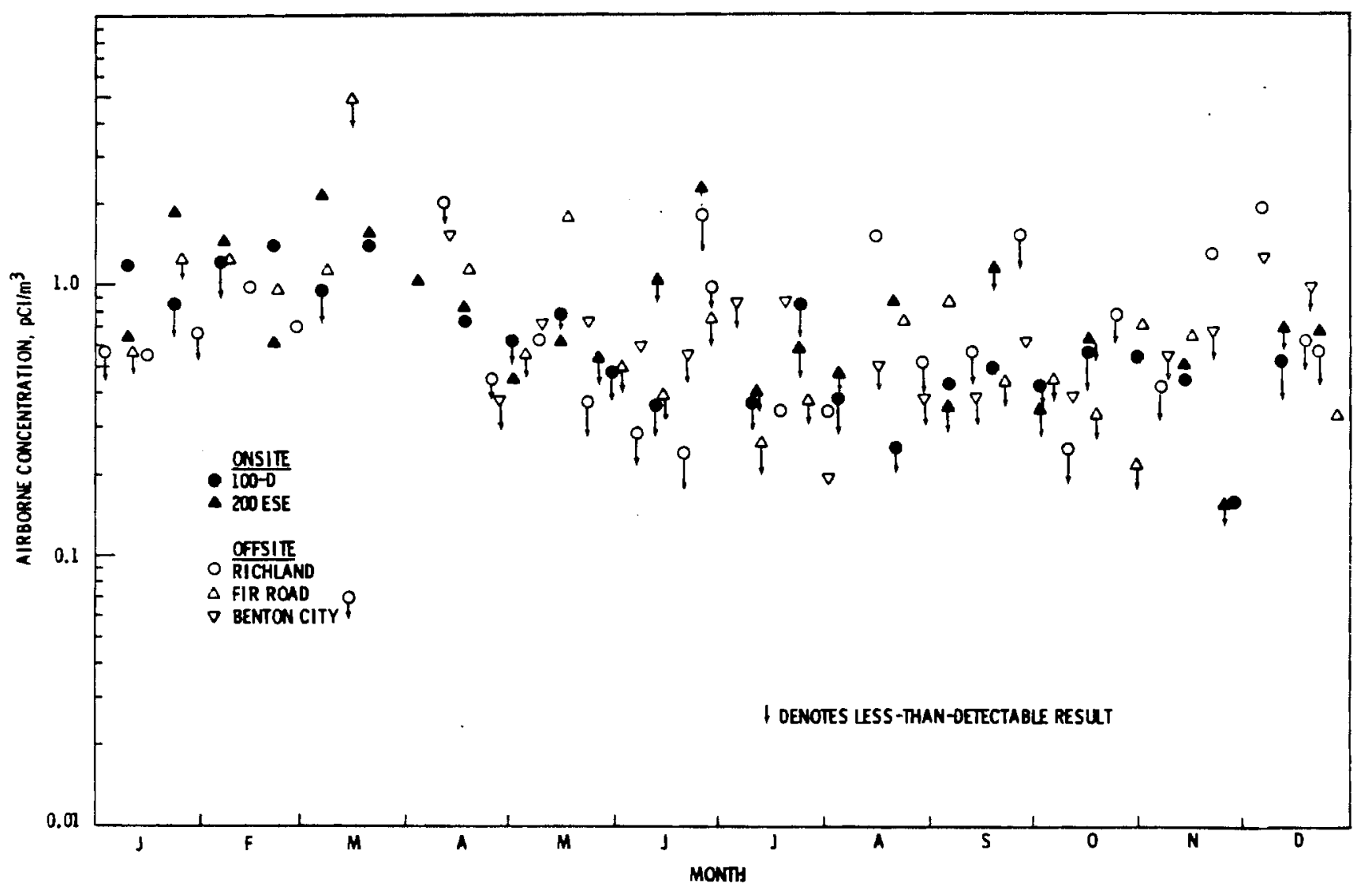

FIGURE 5. Tritiated Water Vapor Concentrations During 1978

For any given radionuclide, the pattern of concentrations found throughout the year was generally similar for each composite group. Concentrations of ${ }^{95} \mathrm{ZrNb}$ and ${ }^{106} \mathrm{Ru}$ increased sharply in the spring of the year. These increases are attributed to the Chinese nuclear test in March. Hanford operations in the 200 Areas were responsible for the slightly higher concentrations of ${ }^{137}$ Cs observed in the 200 East Area several times during 1978.

Except for the higher concentrations of ${ }^{137} \mathrm{Cs}$ in the 200 East Area, radionuclide concentrations were similar at all sampling stations, implying no distinguishable offsite impact from Hanford operations. Onsite impact was limited to the immediate 200 East Area. 

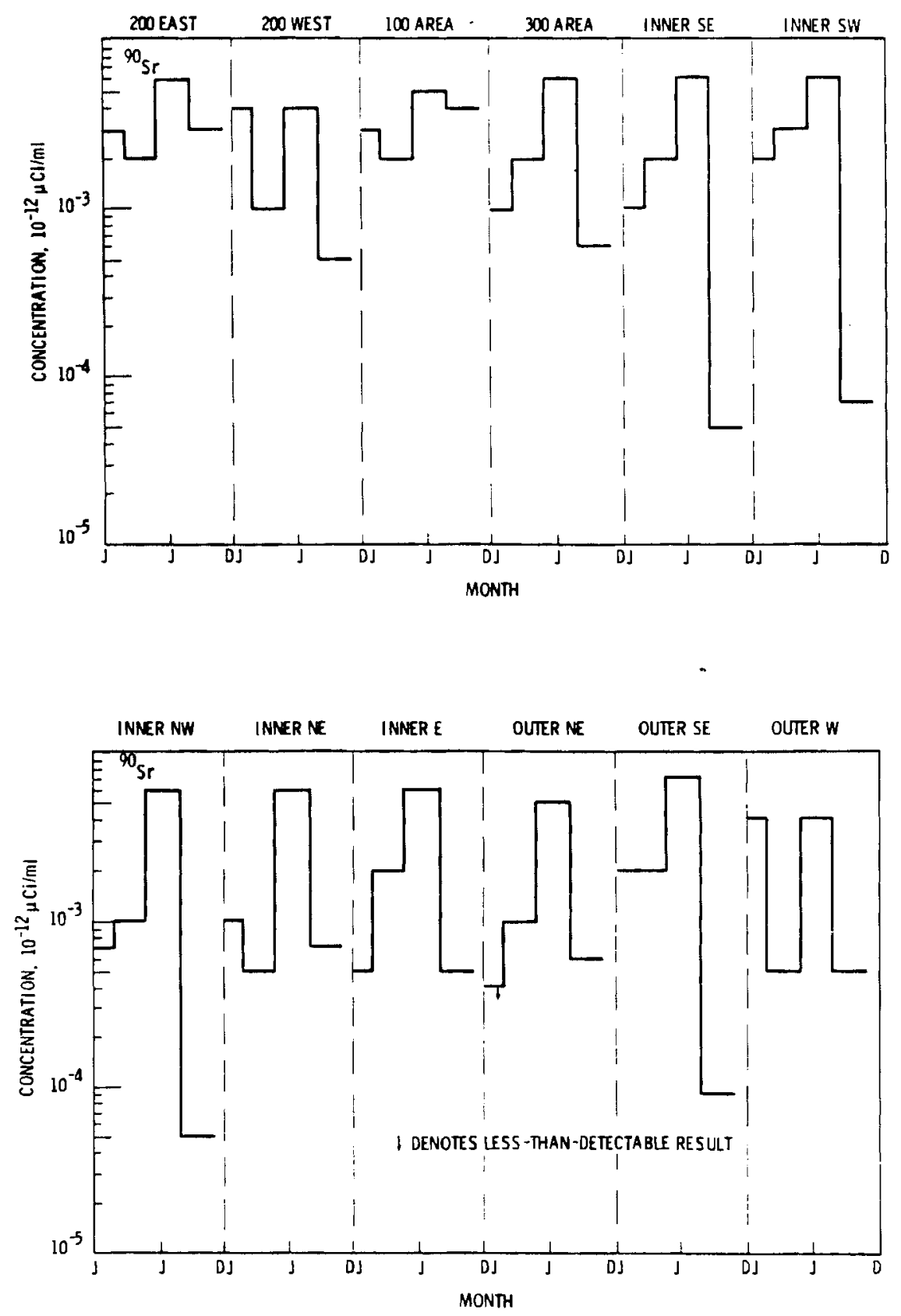

FIGURE 6. Radionuclide Concentrations in Air by Composite Group During 1978 

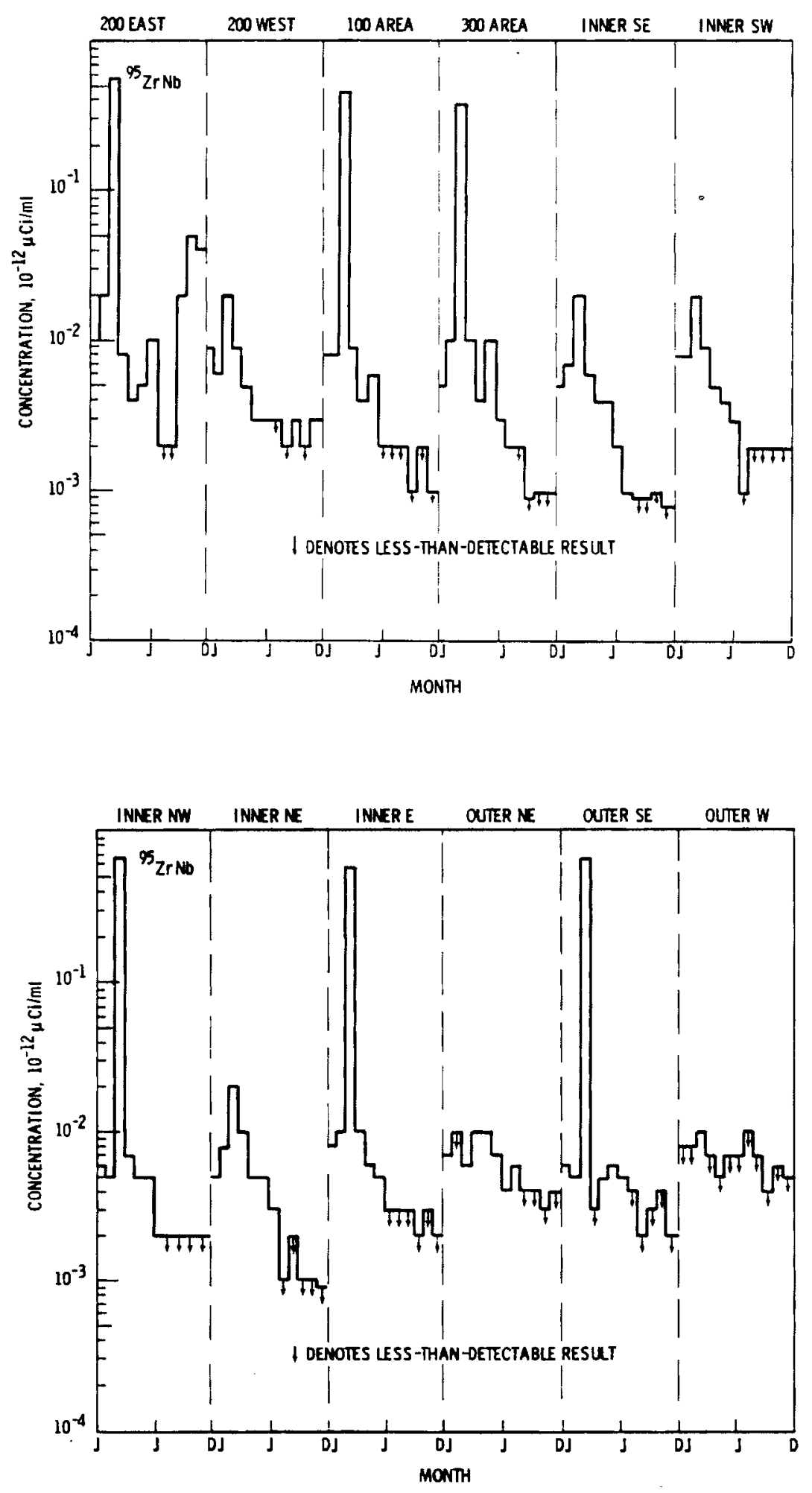

FIGURE 6. (contd) 

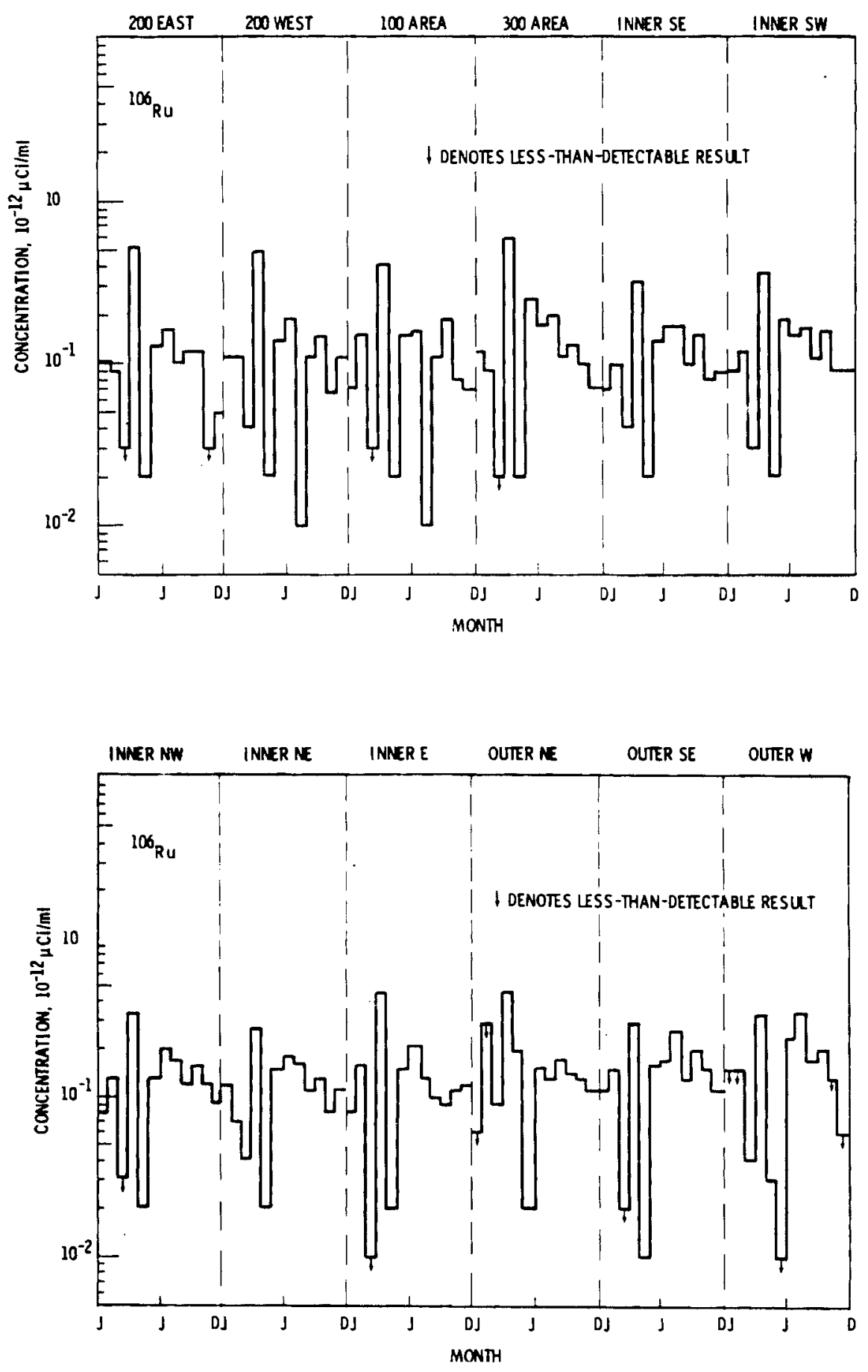

FIGURE 6. (contd) 

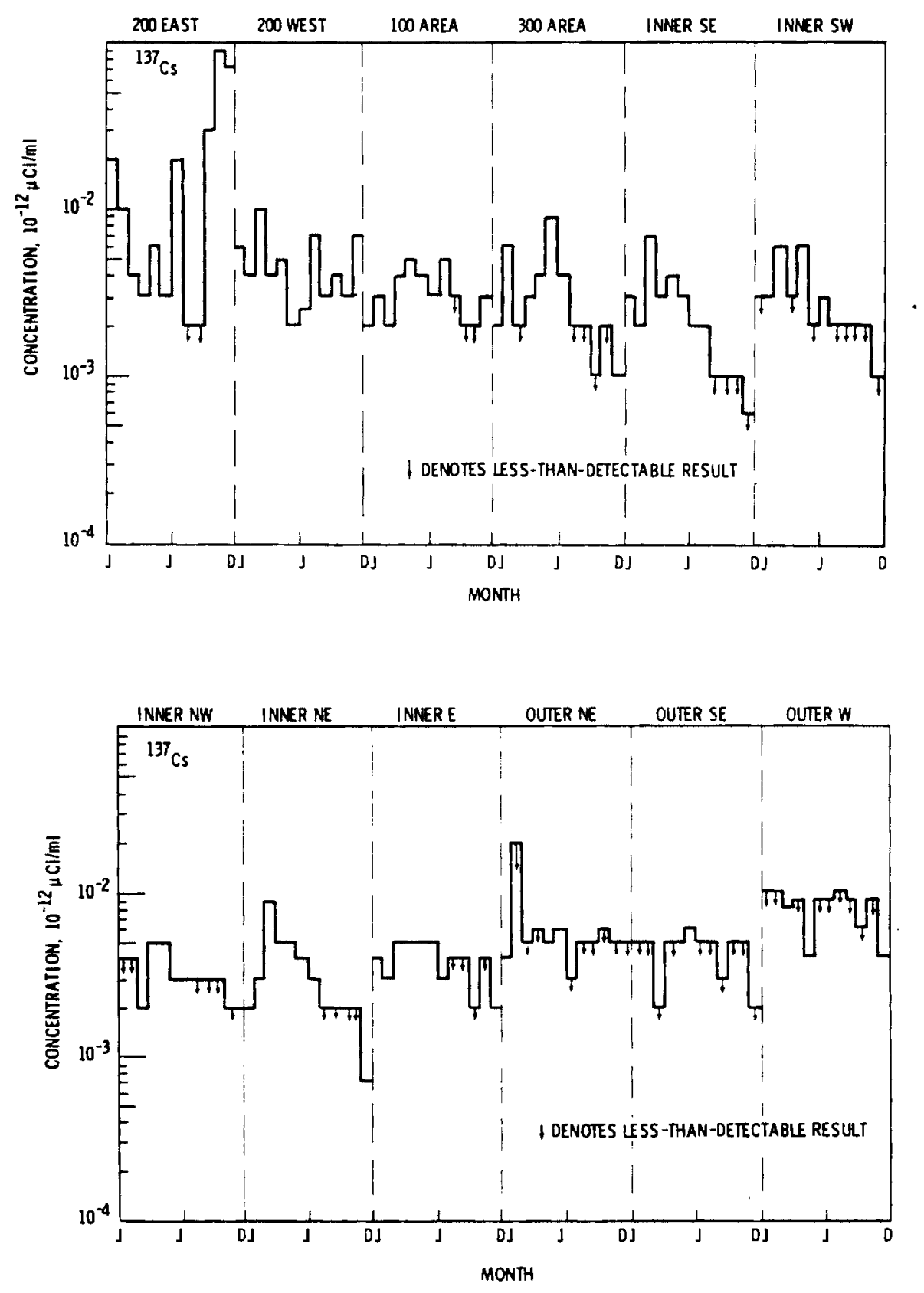

FIGURE 6. (contd) 

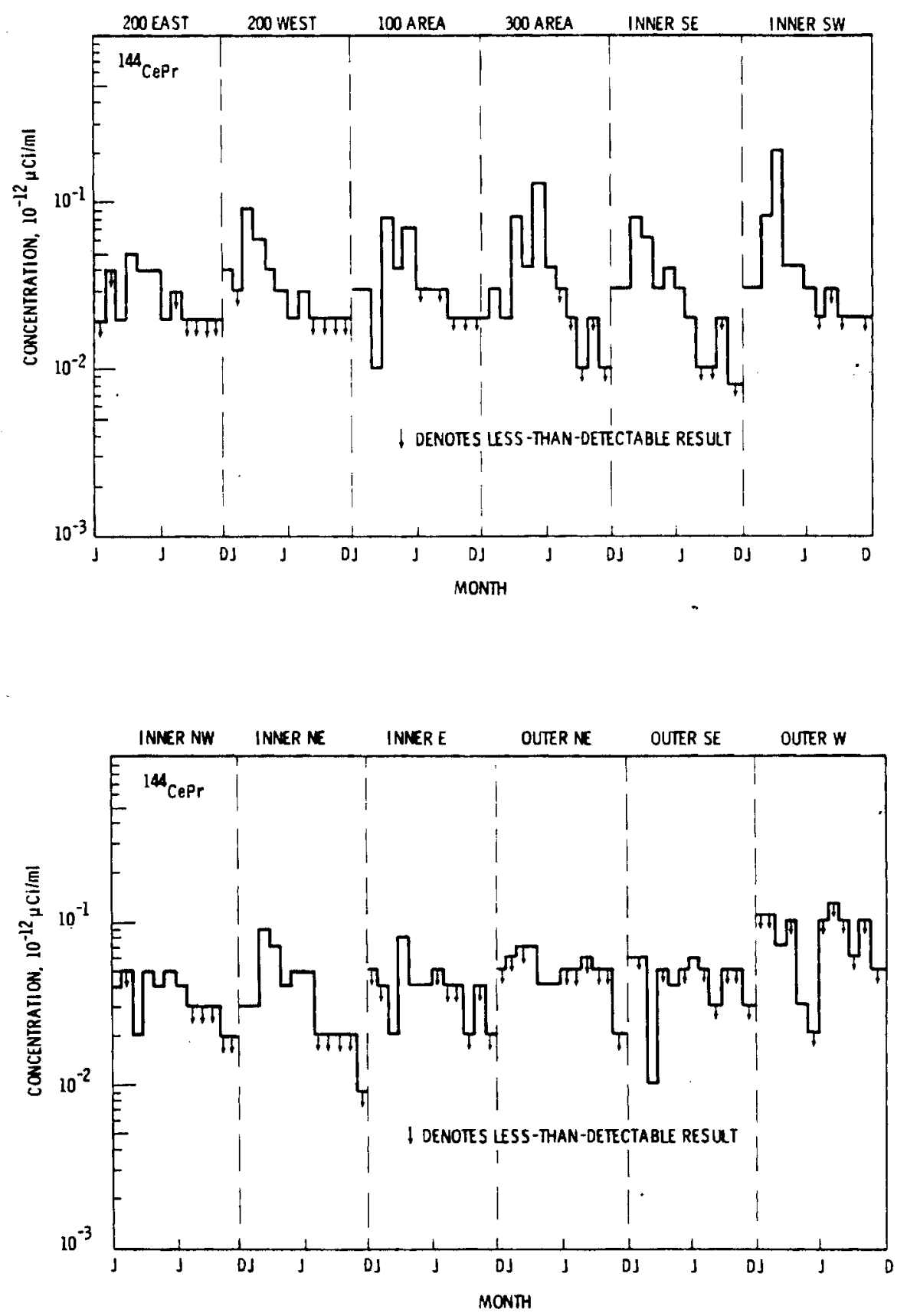

FIGURE 6. (contd) 

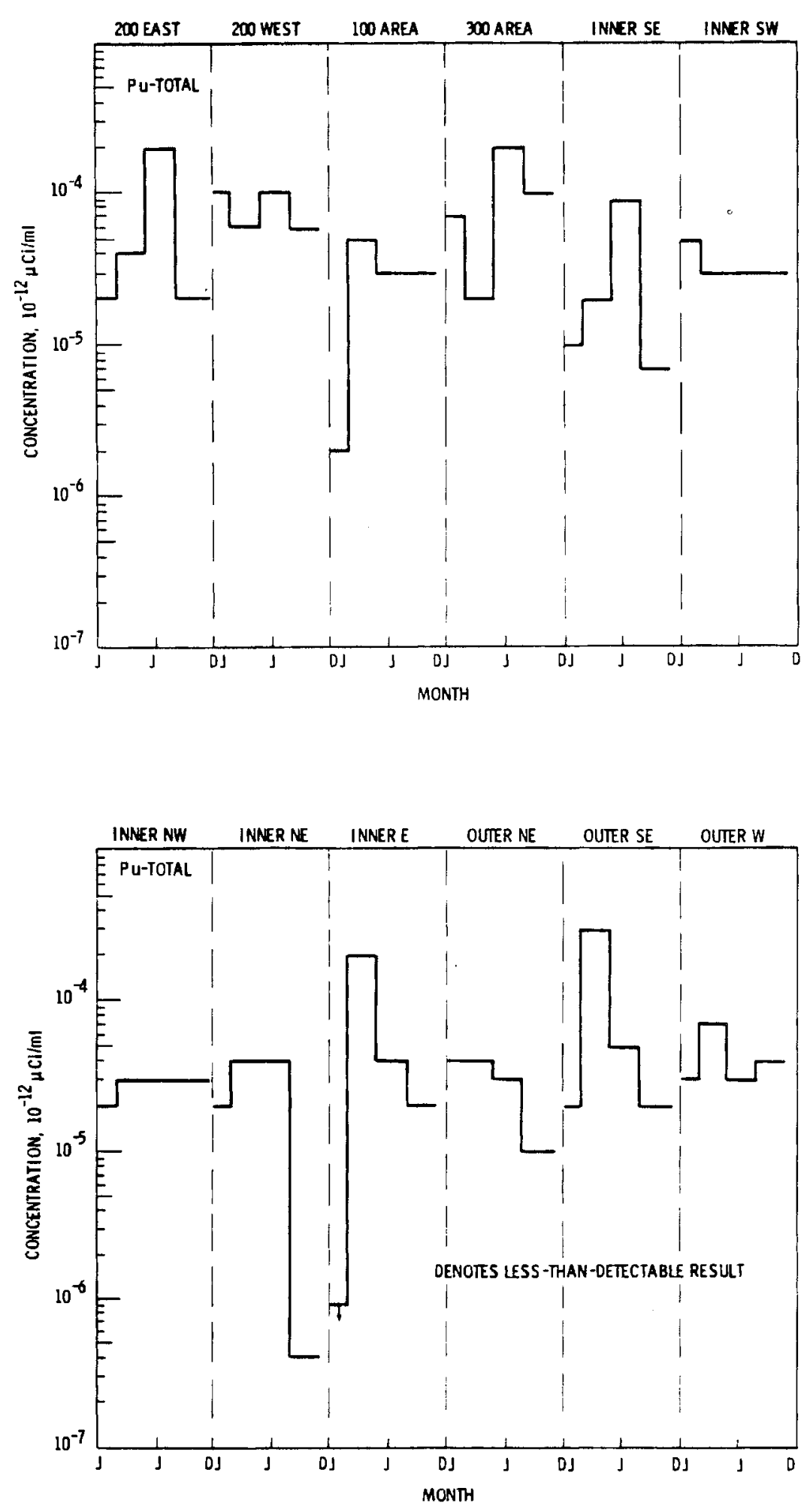

FIGURE 6. (contd) 
The annual average airborne concentrations of specific radionuclides are shown in Table 3 and can be compared with the Concentration Guides of Manual Chapter 0524 Appendix. In all cases, the observed values are a small fraction of the Concentration Guides.

TABLE 3. Airborne Concentrations of Specific Radionuclides During 1978

\begin{tabular}{|c|c|c|c|c|c|c|c|}
\hline \multirow{2}{*}{ Composite Group } & \multicolumn{7}{|c|}{ Annual Average Concentration, $10^{-12} \mu \mathrm{Ci} / \mathrm{ml}(\mathrm{a})$} \\
\hline & $\overline{\mathrm{Be}}$ & ${ }^{90} \mathrm{Sr}$ & ${ }^{95} \mathrm{ZnNb}$ & ${ }^{106} \mathrm{Ru}$ & ${ }^{137} \mathrm{Cs}_{\mathrm{s}}$ & ${ }^{144} \mathrm{CePr}$ & Total $\mathrm{Pu}_{\mathrm{u}}$ \\
\hline \multicolumn{8}{|l|}{ Operational Areas } \\
\hline 100 Areas & $<0.05$ & 0.0035 & $<0.04$ & $<0.12$ & $<0.003$ & $<0.03$ & $<0.0003$ \\
\hline 200 East Area & $<0.02$ & 0.0035 & $<0.06$ & $<0.12$ & $<0.022$ & $<0.03$ & 0.00007 \\
\hline 200 West Area & $<0.06$ & 0.0024 & $<0.01$ & 0.13 & 0.005 & $<0.04$ & 0.00008 \\
\hline 300 Area & $<0.03$ & 0.0024 & $<0.03$ & $<0.16$ & $<0.005$ & $<0.04$ & 0.0001 \\
\hline \multicolumn{8}{|l|}{ Inner Sectors } \\
\hline Northeast & $<0.05$ & 0.0021 & $<0.005$ & 0.12 & $<0.003$ & $<0.04$ & 0.00003 \\
\hline East & $<0.04$ & 0.0023 & $<0.05$ & 0.14 & $<0.004$ & $<0.04$ & $<0.00007$ \\
\hline Southeast & $<0.04$ & 0.0023 & $<0.004$ & 0.12 & $<0.003$ & $<0.03$ & 0.00003 \\
\hline Southwest & $<0.05$ & 0.0028 & $<0.006$ & 0.13 & $<0.003$ & $<0.05$ & 0.00004 \\
\hline Northwest & $<0.04$ & 0.0019 & $<0.06$ & $<0.13$ & $<0.003$ & $<0.04$ & 0.00003 \\
\hline \multicolumn{8}{|l|}{ Outer Sectors } \\
\hline Northeast & $<0.06$ & $<0.0018$ & $<0.006$ & $<0.16$ & $<0.006$ & $<0.05$ & 0.00003 \\
\hline Southeast & $<0.05$ & 0.0028 & $<0.06$ & $<0.15$ & $<0.004$ & $<0.04$ & 0.0001 \\
\hline West & $<0.10$ & 0.0023 & $<0.01$ & $<0.15$ & $<0.008$ & $<0.09$ & 0.00004 \\
\hline Approximate Detection Limit & 0.02 & 0.0005 & 0.002 & 0.1 & 0.005 & 0.03 & 0.00002 \\
\hline Concentration Guide $^{(b)}$ & - & 30 & 1000 & 200 & 500 & 200 & $0.06^{(c)}$ \\
\hline
\end{tabular}

(a) $10^{-12 \mu C i / m l}=1 \mathrm{pCi} / \mathrm{m}^{3}$. A "less-than" value is shown in cases where one or more analytical results were less than the detection 1 imit. The detection limit value was used in place of the actual analytical result in computing the average for these cases.

(b) Manual Chapter 0524 Appendix standards apply to concentrations of radioactivity in excess of those due to naturally occurring or worldwide fallout radioactivity.

(c) Concentration Guide for $239 \mathrm{pu}$. 


\section{COLUMBIA RIVER MONITORING}

Columbia River water was sampled upstream (at Priest Rapids Dam, Vernita Bridge, and the 100-B Area) and downstream (at the 300 Area forebay and the Richland pumping dock) for radiological, chemical, physical and/or biological analyses. Information on Columbia River sampling has been presented and evaluted in the 1978 environmental surveillance report (Houston and Blumer 1979). A brief summary of this effort is included here for the sake of completeness.

Analyses for ${ }^{3} \mathrm{H}, \mathrm{U}$, and ${ }^{90} \mathrm{Sr}$ in Columbia River water were done for integrated water samples obtained at the 100-B Area and at Richland. Samples were collected weekly and grouped into a composite for analysis monthly. Samples for analysis of gamma-emitting radionuclides, ${ }^{129} \mathrm{I}$, and plutonium in river water were obtained from filter-resin samplers at Priest Rapids Dam and the 300 Area forebay (Fix and Robertson 1976). These samples were collected biweekly and both the filter and resin portions of the sample were analyzed for gamma-emitting radionuclides. The resin was composited monthly and an aliquot analyzed for ${ }^{129}$ I using neutron activation analysis (Brauer and Kaye 1973). Quarterly, specific analysis for plutonium was done on a composite cf the biweekly filter and resin samples.

In Figure 7, concentrations of soluble radionuclides collected from the resin at Priest Rapids Dam are compared with those from the 300 Area forebay. Gaps in the histograms occur when no concentration is reported by the analytical laboratory. Potassium-40 is a naturally occurring radionuclide. The other radionuclides result from fallout from past atmospheric nuclear tests and, downstream, from Hanford operations. Throughout $1978,{ }^{60} \mathrm{Co}$ and ${ }^{129}$ I were the only radionuclides observed at higher concentrations downstream than upstream. Small quantities of these radionuclides routinely reach the river as a result of current and past Hanford operations. In all cases, the concentrations of radionuclides observed in Columbia River water are less than $1 \%$ of the Concentration Guides. 

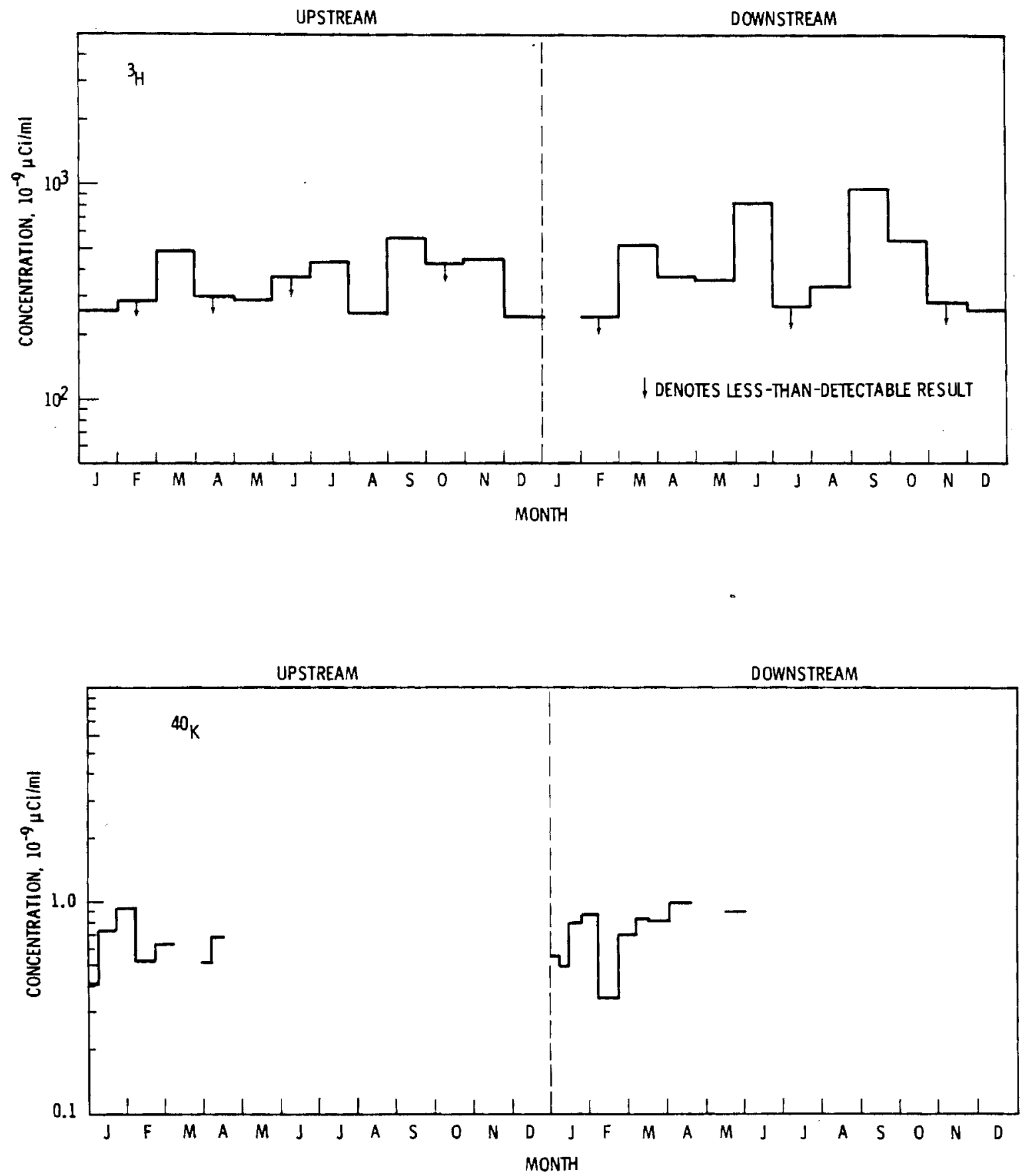

FIGURE 7. Radionuclide Concentrations in Columbia River Water During 1978 

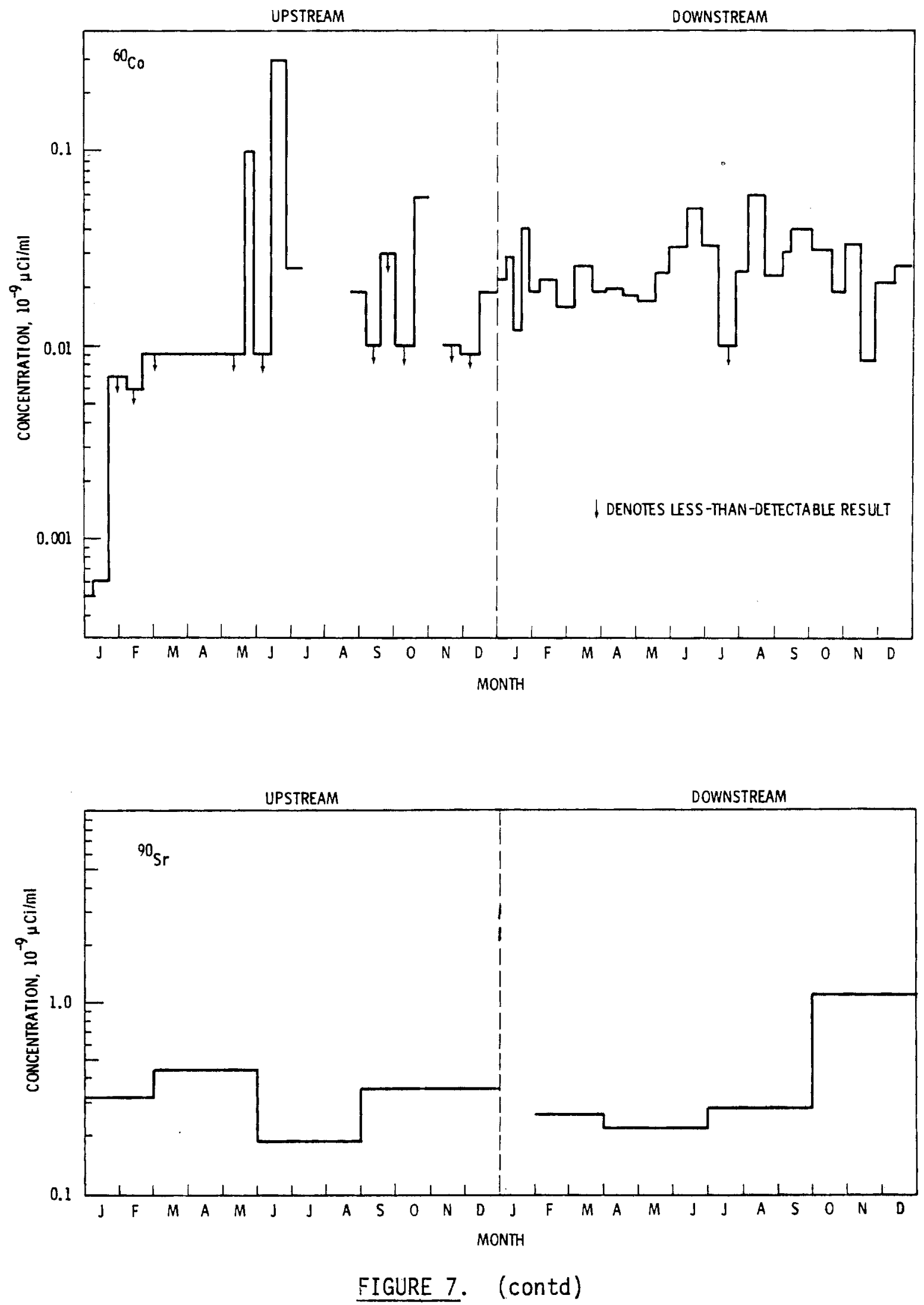

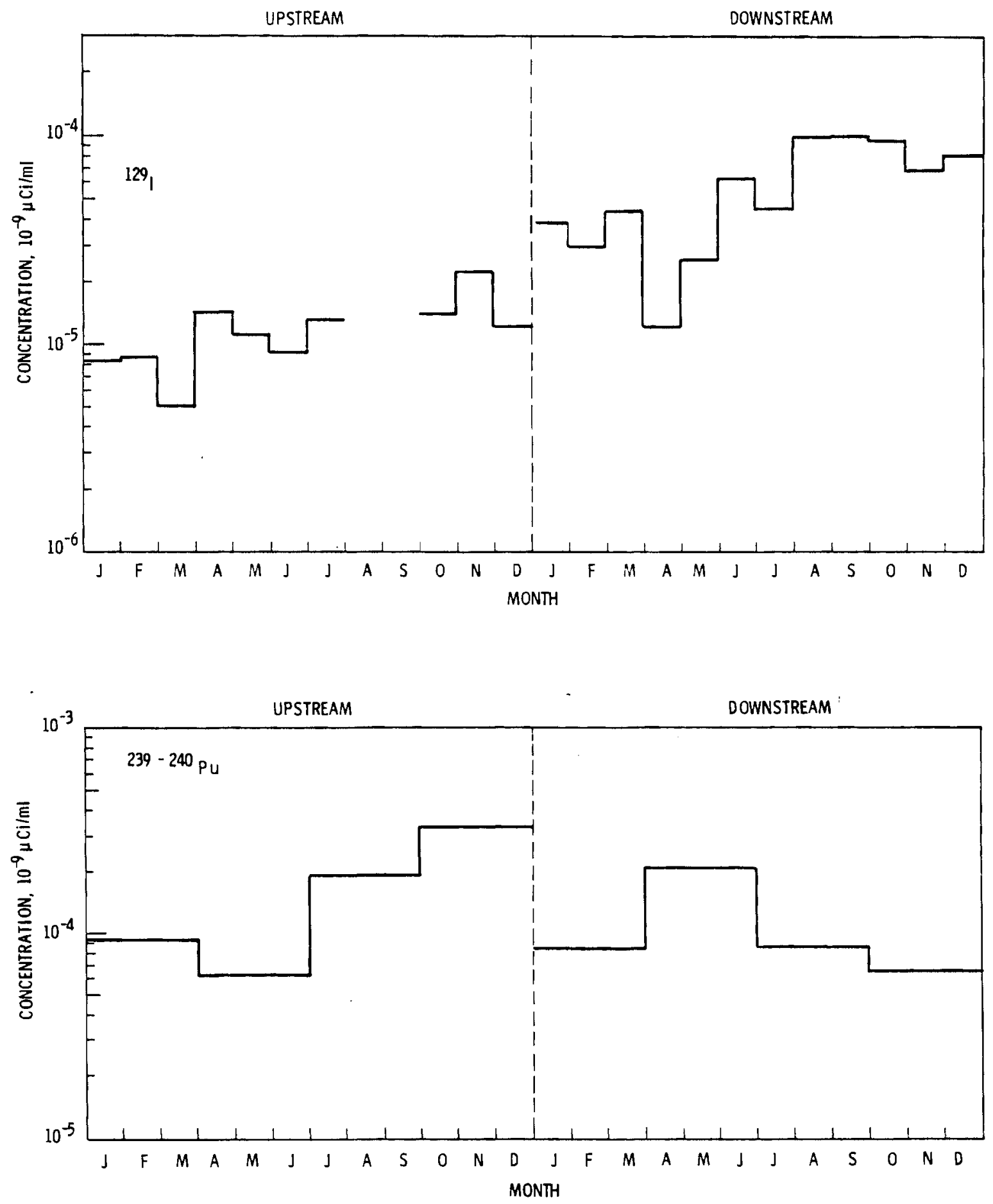

FIGURE 7. (contd) 


\section{DITCHES, PONDS, AND TRENCHES}

Surface water that has accumulated on the Hanford Site as a result of the disposal of process water was sampled routinely in 1978. Grab samples were collected and analyzed for alpha-, beta-, and gamma-emitting radionuclides. In some instances radiochemical analyses for ${ }^{90} \mathrm{Sr}$, uranium, and plutonium were done. Shown in Figure 8 are the locations of the ditches, ponds, and trenches sampled on the Hanford Site during 1978.

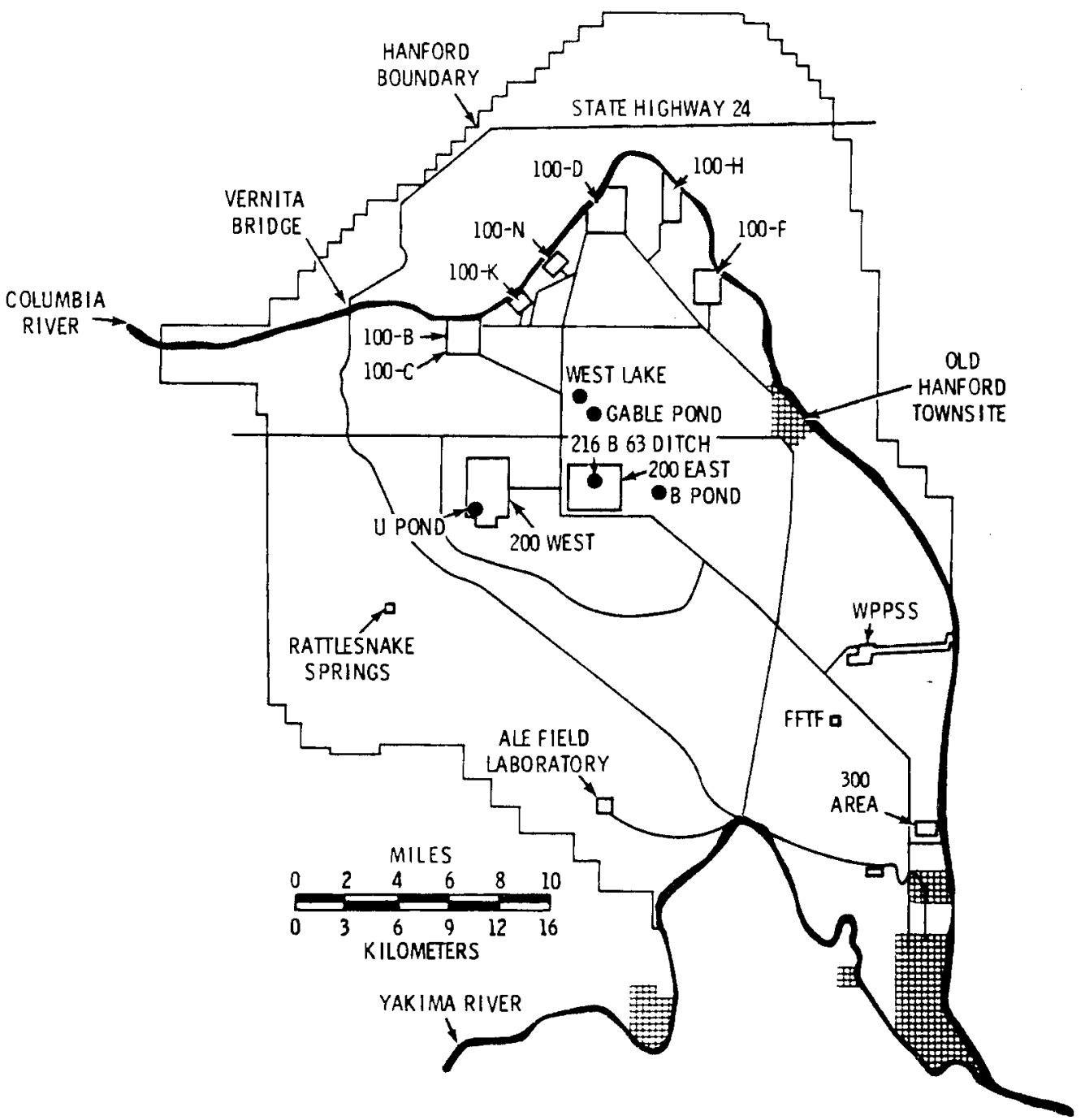

FIGURE 8. Surface Water Areas Sampled During 1978 
The results of analyses for total alpha- and total beta-emitter activity and for ${ }^{90} \mathrm{Sr}$ in a 11200 Area and vicinity surface waters are shown in Figures 9 through 11, respectively. West Lake, a naturally occurring watertable-intersection pond that also serves as a natural basin for a relatively large watershed area, had the highest levels of total alpha- and total betaemitter activity. No waste water is discharged directly into West Lake. The radionuclides that have accumulated in the pond are uranium and ${ }^{90} \mathrm{Sr}$. Uranium (accounting for the alpha-emitter activity) may have been leaching from the soil during the entire history of West Lake's existence. The presence of ${ }^{90} \mathrm{Sr}$ is attributed to worldwide fallout in rainwater. A possible further cause of the relatively high radionuclide content of this pond is the concentrating effect of the continual evaporation of water. By contrast, the

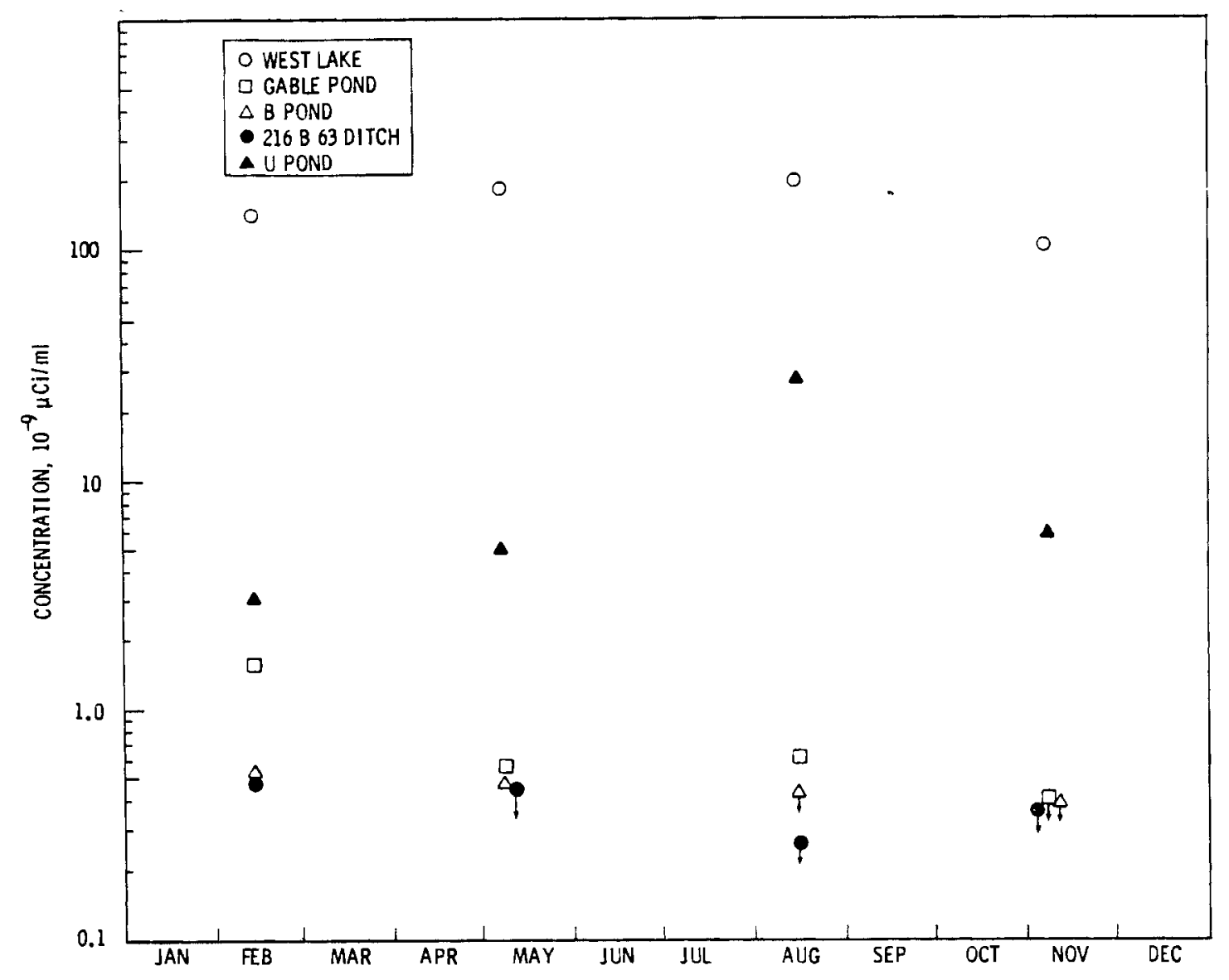

FIGURE 9. Total Alpha-Emitter Activities Observed in 200 Area Ponds During 1978 


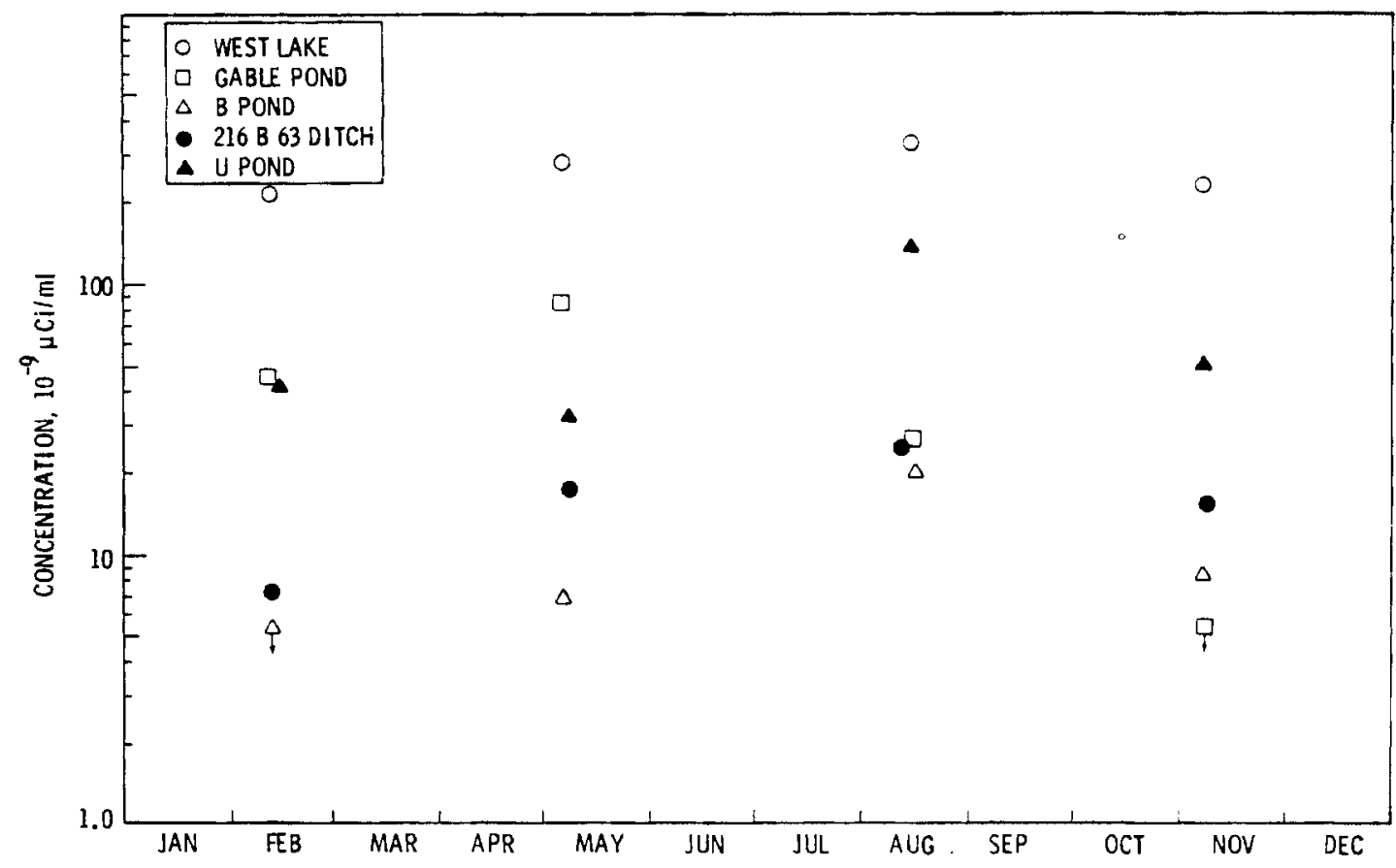

FIGURE 10. Total Beta-Emitter Activities Observed in 200 Area Ponds During 1978

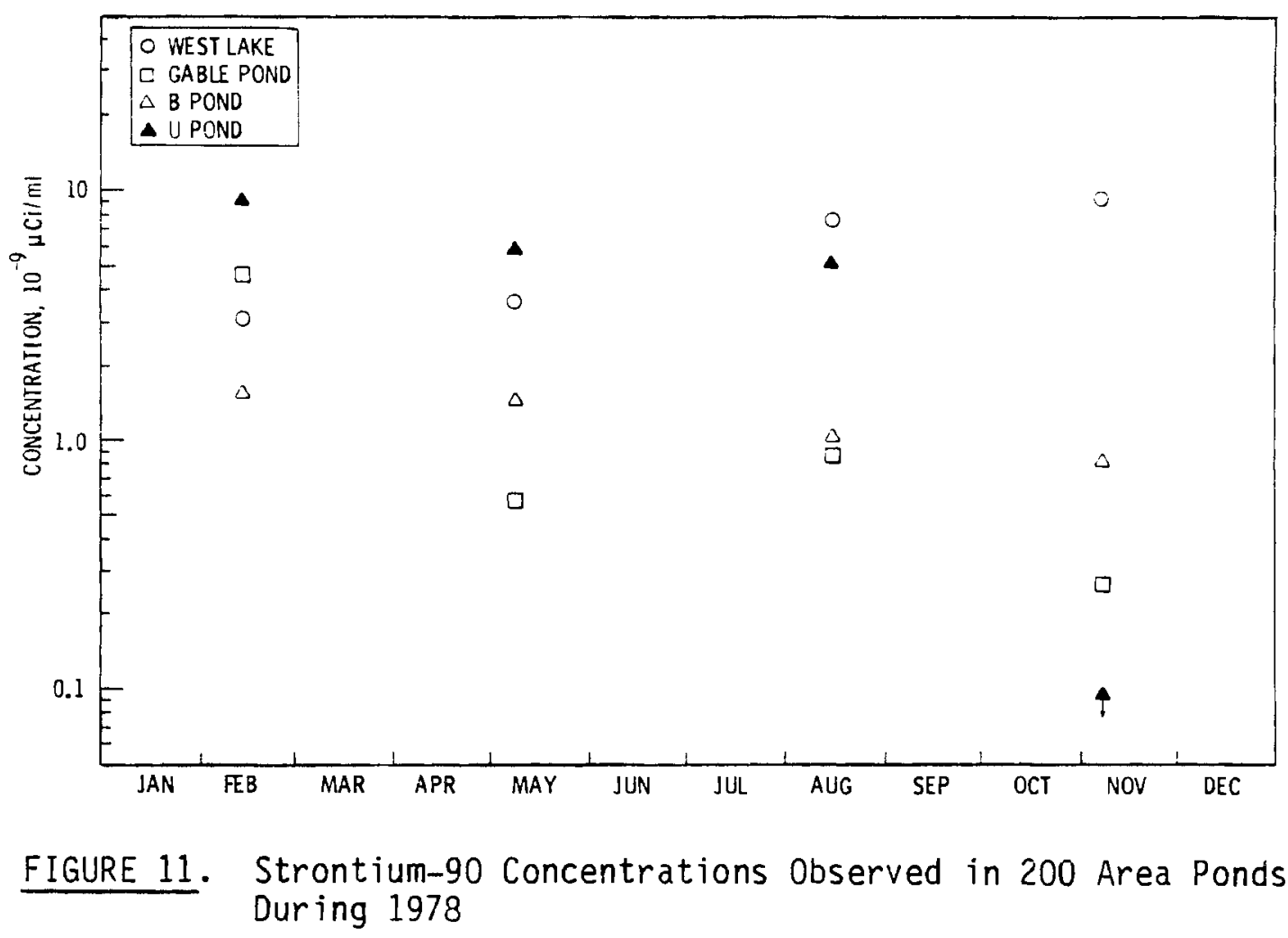


waste water discharged to other ponds has been diluted with river water containing relatively low concentrations of ${ }^{90} \mathrm{Sr}$ and uranium.

The results of gamma spectroscopy and ${ }^{90} \mathrm{Sr}$ analyses of surface-water samples are shown in Table 4. Both ${ }^{137} \mathrm{Cs}$ and ${ }^{90} \mathrm{Sr}$ were present at low concentrations in many of the samples. These concentrations, however, are typical of those observed in recent years.

TABLE 4. Radionuclide Concentrations in Surface Water Samples During 1978

\begin{tabular}{|c|c|c|c|c|c|}
\hline . & & Concen & ration, $10^{-9}$ & $\mathrm{Ci} / \mathrm{n}$ & (a) \\
\hline Location & Date & ${ }^{90} \mathrm{Sr}$ & ${ }^{95} \mathrm{ZrNb}$ & & ${ }^{37} \mathrm{Cs}_{5}$ \\
\hline West Lake & $2 / 13$ & $3.1 \pm 0.3$ & $\star$ & 11 & \pm 10 \\
\hline & $5 / 8$ & $3.6 \pm 0.3$ & $\star$ & & * \\
\hline & $8 / 15$ & $7.5 \pm 0.3$ & * & 10 & \pm 10 \\
\hline & $11 / 7$ & $9.0 \pm 1.1$ & * & & * \\
\hline Gable Pond & $2 / 13$ & $4.4 \pm 0.2$ & $8.7 \pm 1.2$ & 22 & \pm 2.1 \\
\hline & $5 / 8$ & $0.6 \pm 0.1$ & \pm 1.3 & 53 & \pm 2.3 \\
\hline & $8 / 15$ & $0.8 \pm 0.1$ & * & 29 & \pm 2.3 \\
\hline & $11 / 7$ & $0.3 \pm 0.1$ & * & & * \\
\hline B Pond & $2 / 13$ & $1.5 \pm 0.1$ & $1.5 \pm 1.3$ & 9. & \pm 2.1 \\
\hline & $5 / 8$ & $1.4 \pm 0.1$ & * & 2. & \pm 2.1 \\
\hline & $8 / 15$ & $1.0 \pm 0.1$ & * & 6. & \pm 2.2 \\
\hline & $11 / 7$ & $0.8 \pm 0.1$ & * & 3. & \pm 2.1 \\
\hline 216 B 63 Ditch & $2 / 13$ & & * & & * \\
\hline & $5 / 8$ & & $4.3 \pm 3.1$ & 13 & \pm 5.2 \\
\hline & $8 / 15$ & & * & 21 & \pm 7.8 \\
\hline & $11 / 7$ & & * & & * \\
\hline$U$ Pond & $2 / 13$ & $8.8 \pm 0.3$ & $3.8 \pm 1.2$ & 11 & \pm 2.1 \\
\hline & $5 / 8$ & $5.7 \pm 0.1$ & $4.6 \pm 1.3$ & 13 & \pm 2.1 \\
\hline & $8 / 15$ & $4.9 \pm 0.1$ & * & & \pm 2.1 \\
\hline & $11 / 7$ & $\star$ & * & & $\star$ \\
\hline
\end{tabular}

$$
\text { Detection Limit }{ }^{(b)}
$$$$
0.2
$$$$
2.4
$$$$
5.1
$$

* Less than detection limit.

(a) $10^{-9} \mu \mathrm{Ci} / \mathrm{ml}=1 \mathrm{pCi} / 2$. A blank indicates that no analys is was made.

(b) The detection limit is the average of the individual detection limits for the less-than-detectable results for each radionuclide. 
To demonstrate the representativeness of surface water samples, replicate samples are collected periodically for analysis. During 0ctober of 1978, five samples of water were collected at widely scattered locations on B Pond. A rowboat was used so that all samples could be collected at least 15 meters (50 feet) from the shore. Half of each sample was poured into a compositing container to provide an overall average sample, which was then divided into aliquots to provide five samples for replicate analysis. The remaining half of each sample was analyzed separately. Presented in Table 5 is a summary of the replicate sampling results. Samples 1 through 5 are those taken from various locations on the pond and Samples 6 through 10 are the replicate samples drawn from the pond composite. The variability in the analysis is greater than that associated with the sampling location and is of an acceptable magnitude. The ${ }^{90} \mathrm{Sr}$ result for Sample 1 is apparently a laboratory artifact, since a concentration of this magnitude would have significantly altered the replicate samples drawn from the pond composite.

TABLE 5. B Pond Replicate Sampling During 1978

\begin{tabular}{|c|c|c|c|c|}
\hline \multirow[b]{2}{*}{$\begin{array}{l}\text { Sample } \\
\text { Number }\end{array}$} & \multicolumn{4}{|c|}{ Concentration, $10^{-9} \mu \mathrm{Ci} / \mathrm{ml}$ (a) } \\
\hline & $\begin{array}{l}\text { Total } \\
\text { Alpha }\end{array}$ & $\begin{array}{l}\text { Total } \\
\text { Beta } \\
\end{array}$ & ${ }^{90} \mathrm{Sr}$ & ${ }^{137} \mathrm{Cs}$ \\
\hline 1 & $0.34 \pm 0.35$ & \pm 3.7 & $\pm 0.09^{(b)}$ & $6.6 \pm 2.1$ \\
\hline 2 & $0.44 \pm 0.26$ & \pm 3.6 & $1.0 \pm 0.09$ & $5.8 \pm 2.1$ \\
\hline 3 & $0.32 \pm 0.25$ & \pm 3.7 & $1.3 \pm 0.09$ & $6.0 \pm 2.1$ \\
\hline 4 & $0.39 \pm 0.33$ & \pm 3.6 & $1.0 \pm 0.09$ & $5.5 \pm 2.1$ \\
\hline 5 & $0.37+0.28$ & +3.5 & $1.0+0.09$ & $5.8+2.1$ \\
\hline Average & $0.37 \pm 0.05$ & $10.5 \pm 1.1$ & $1.1 \pm 0.15$ & $5.9 \pm 0.4$ \\
\hline 6 & $0.44 \pm 0.30$ & $6.3 \pm 3.5$ & $1.2 \pm 0.20$ & $6.3 \pm 2.1$ \\
\hline 7 & $0.44 \pm 0.35$ & $9.8 \pm 5.3$ & $1.0 \pm 0.18$ & $5.5 \pm 2.1$ \\
\hline 8 & $0.65 \pm 0.47$ & \pm 5.2 & $1.2 \pm 0.20$ & $4.9 \pm 2.1$ \\
\hline 9 & $0.24 \pm 0.29$ & $6.6 \pm 5.2$ & $0.78 \pm 0.12$ & $5.4 \pm 2.1$ \\
\hline 10 & $\underline{0.51+0.44}$ & $10+5.1$ & $0.78+0.12$ & $5.3+2.1$ \\
\hline Average & $0.46 \pm 0.15$ & $8.6 \pm 2.0$ & $0.99 \pm 0.21$ & $5.5 \pm 0.5$ \\
\hline
\end{tabular}

(a) $10^{-9} \mathrm{HCi} / \mathrm{ml}=1 \mathrm{pCi} / \mathrm{l}$.

(b) Not included in average. 


\section{WILDLIFE}

The Hanford Site serves as a refuge for migratory and resident waterfowl, dry-land game birds, and a variety of mammals. All of these animals have access to swamps, ponds, and trenches on the site that receive low-level radioactive wastes. Ingestion of the waste water or contaminated vegetation may result in measurable quantities of radionuclides being incorporated in the an imals' tissues.

Selected wildlife were collected throughout the Hanford environs as an indicator of radionuclide accessibility and potential transfer through the food chain leading to man. Although the Hanford Site south of the Columbia River is not open to public hunting, several of its wildlife species are game animals that could be taken by hunters during the time they spend offsite.

\section{GAME BIROS}

Garma spectroscopy and ${ }^{90} \mathrm{Sr}$ analyses were performed on $454-\mathrm{g}$ (1-1b) samples of muscle tissue from game birds collected during 1978. The results of these analyses are shown in Table 6. Ducks were collected from each of the

TABLE 6. Radionuclide Concentrations in Game Bird Muscle Samples During 1978

\begin{tabular}{|c|c|c|c|c|c|c|c|c|c|c|c|}
\hline \multirow[b]{3}{*}{ Location } & \multirow[b]{3}{*}{ Species } & \multirow{3}{*}{$\begin{array}{l}\text { No. of } \\
\text { Samples }\end{array}$} & \multicolumn{9}{|c|}{ Concentration, $10^{-6} \mu \mathrm{Ci} / \mathrm{g}$ Wet Weight ${ }^{(\mathrm{a})}$} \\
\hline & & & \multicolumn{3}{|c|}{${ }^{40}{ }_{K}$} & \multicolumn{3}{|c|}{${ }^{90} \mathrm{Sr}$} & \multicolumn{3}{|c|}{${ }^{137} \mathrm{Cs}$} \\
\hline & & & Max. & Min. & Average & Max. & Min. & Average & Max. & Min. & Average \\
\hline 300 Pond & Ducks & 4 & 3.1 & * & $<3.2$ & * & * & * & * & * & * \\
\hline U Pond & Ducks & 2 & 2.2 & * & $<3.5$ & * & * & * & 16 & 4.7 & 10 \\
\hline Gable Pond & Ducks & 4 & 2.2 & * & $<3.2$ & * & * & * & 117 & 0.2 & 39 \\
\hline West Lake & Ducks & 3 & 2.0 & * & $<3.2$ & 0.02 & * & $<0.02$ & 52 & 0.5 & 25 \\
\hline B Pond & Ducks & 3 & 2.7 & * & $<3.0$ & * & * & * & 34 & 0.6 & 12 \\
\hline Columbia River & Ducks & 10 & 3.7 & 2.0 & 2.4 & 0.13 & $\star$ & $<0.03$ & $\star$ & * & * \\
\hline Columbia River & Geese & 2 & 3.0 & 2.2 & 2.6 & & & & ^ & * & * \\
\hline 100 Areas & Pheasants & 6 & 2.7 & 1.8 & 2.4 & 0.58 & * & $<0.13$ & * & * & * \\
\hline 100 Areas & Quail & 3 & * & * & * & 0.84 & * & $<0.25$ & $\star$ & * & * \\
\hline 300 Area & Quail & 1 & & & * & & & 0.13 & & & * \\
\hline \multicolumn{2}{|c|}{ Detection Limit ${ }^{(b)}$} & & & & 2.0 & & & 0.02 & & & 0.1 \\
\hline
\end{tabular}

* Less than detection Timit.

(a) $10^{-6} \mu \mathrm{Ci} / \mathrm{g}=1 \mathrm{pCi} / \mathrm{g}$. A blank indicates that no analysis was made.

(b) The detection limit is the average of the individual detection limits for the less-than-detectable results for each radionuclide. 
larger trenches and ponds on the Hanford Site and along the Columbia River. Only those radionuclides observed at levels higher than the detection limit are shown in Table 6 . Cesium-137 and ${ }^{90} \mathrm{Sr}$ were the only artificially produced radionuclides detected in the muscle samples. The presence of ${ }^{90} \mathrm{Sr}$ in waterfowl samples is attributed to worldwide fallout, since the concentrations found in onsite and Columbia River birds are similar. Cesium-137 activity in the waterfowl is probably the result of uptake during residence on the surface-water ponds in the 200 Areas. The maximum concentration found is similar to that measured in previous years; however, the average concentration is down considerably, indicating perhaps that the radionuclide is becoming less accessible in the food chain.

If an individual consumed $454 \mathrm{~g}$ ( $1 \mathrm{lb}$ ) of meat from the duck containing the highest levels of ${ }^{137} \mathrm{Cs}$ observed during $1978\left(117 \times 10^{-6} \mu \mathrm{Ci} / \mathrm{g}\right)$, that individual would incur 50-year internal dose commitments of about 4 mrem to the total body and 4 mrem to the bone. The major portion of these doses would .be received during the first year following ingestion.

\section{DEER}

Muscle, liver, and bone samples were obtained from road-killed deer on the Hanford Site and analyzed for radionuclide content. In general, the radionuclide concentrations seen in muscle tissue (shown in Table 7 ) were lower than those observed in the 1977 samples. Naturally occurring $40_{K}$ was observed, as expected, in all muscle samples.

Plutonium was detected in all liver samples analyzed, in concentrations that were very small but higher than those observed in recent years. Concentrations of ${ }^{90} \mathrm{Sr}$ measured in the Hanford deer tissues were similar to concentrations observed in the past in deer from other parts of the country. The ${ }^{137}$ Cs concentrations found in muscle samples may be due to Hanford operations, but the values are too small to be conclusive. A person consuming $22.7 \mathrm{~kg}(50 \mathrm{lb})$ of deer muscle tissue containing the maximum observed concentration of ${ }^{137} \mathrm{Cs}\left(0.13 \times 10^{-6} \mu \mathrm{Ci} / \mathrm{g}\right)$ would receive a 50 -year dose commitment of about 0.2 mrem to the total body. 
TABLE 7. Radionuclide Concentrations in Deer Tissues During 1978

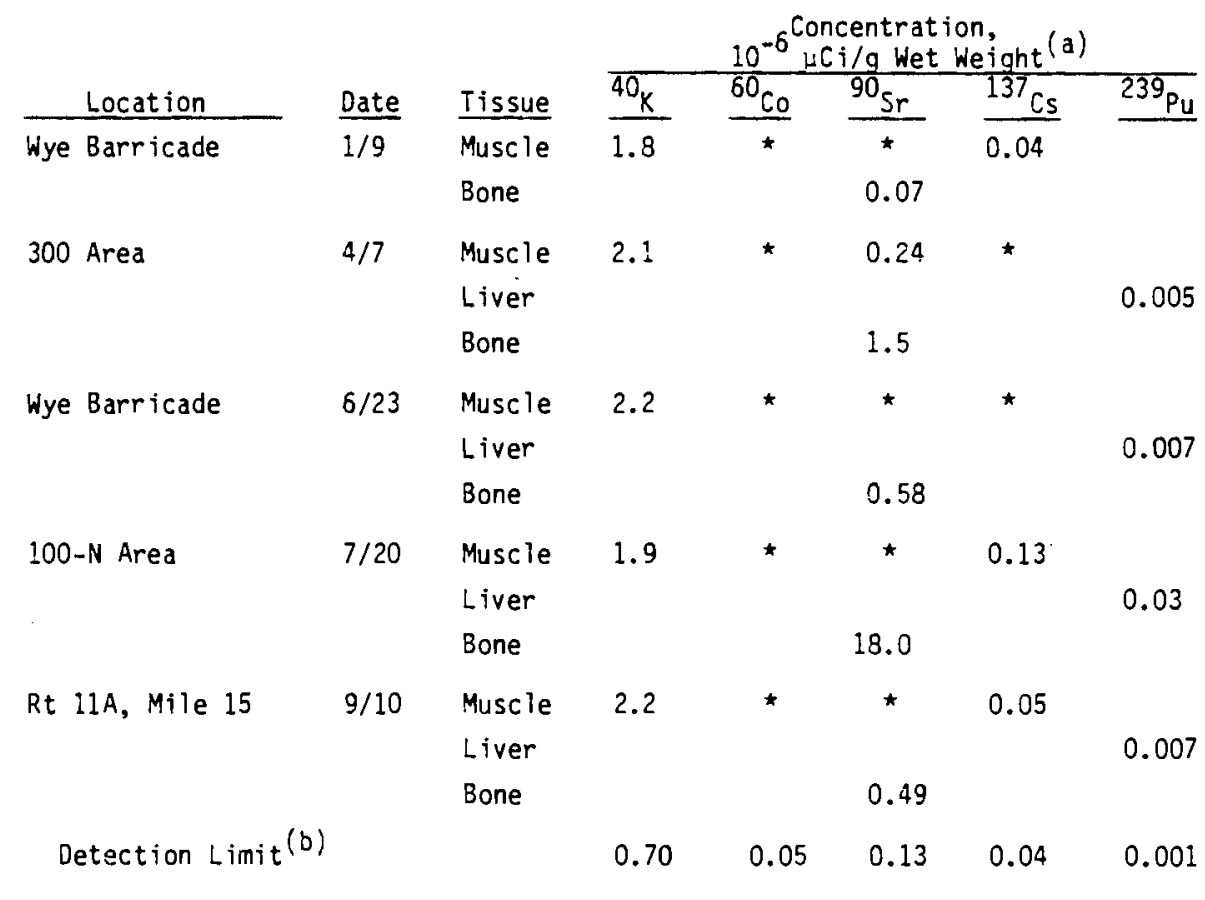

* Less than detection limit.

(a) $10^{-6} \mu \mathrm{Ci} / \mathrm{g}=1 \mathrm{pCi} / \mathrm{g}$. A blank indicates that no analysis was made.

(b) The detection limit is the average of the individual detection limits for the less-than-detectable results for each radionuclide.

\section{MICE AND RABBITS}

Mice and rabbits collected around surface waters and radioactive waste sites on the Hanford reservation were analyzed for selected radionuclides to determine the accessibility of radioactive material to small marmals. Because of their small size, specific mouse organs are not analyzed. The whole mouse provides a sensitive indicator of the accessibility of radioactivity. Rabbits, on the other hand, may be hunted as food for human consumption; therefore the radionuclide content of muscle and other tissues is of interest. The results of these analyses are shown in Tables 8 and 9.

Rabbit bone samples collected around the B-C crib (Table 8) had somewhat lower ${ }^{90} \mathrm{Sr}$ concentrations than in previous years. Cesium-137 concentrations in muscle tissue samples were similar to those cbserved in past years, as were the ${ }^{239} \mathrm{Pu}$ concentrations in liver tissues. 
TABLE 8. Radionuclide Concentrations in Rabbit Tissues During 1978

\begin{tabular}{|c|c|c|c|c|c|c|c|}
\hline & & & & $10^{-6}$ & $\begin{array}{l}\text { Concentra } \\
\mu \mathrm{Ci} / \mathrm{g} \text { Wet }\end{array}$ & $\begin{array}{l}\text { ion, } \\
\text { leight (a) }\end{array}$ & \\
\hline Location & Date & Tissue & $40_{K}$ & ${ }^{60} \mathrm{CO}_{0}$ & ${ }^{90} \mathrm{Sr}$ & ${ }^{137} \mathrm{Cs}_{\mathrm{S}}$ & $239 \mathrm{pu}_{\mathrm{u}}$ \\
\hline B Pond & $2 / 14$ & Muscle & 2.6 & * & & 0.71 & \\
\hline & & Bone & & & 14.0 & & \\
\hline$B$ Pond & $2 / 14$ & Muscle & 2.7 & * & & 0.50 & \\
\hline & & Bone & & & 4.0 & & \\
\hline 200 B-C Crib & $4 / 5$ & Muscle & 3.1 & * & & 0.65 & \\
\hline & & Liver & & & & & * \\
\hline & & Bone & & & 0.07 & & \\
\hline 200 West Area & $4 / 10$ & Muscle & * & * & & 0.28 & \\
\hline & & Liver & & & & & 0.001 \\
\hline & & Bone & & & 2.4 & & \\
\hline 200 West Area & $4 / 10$ & Muscle & * & * & & 0.48 & \\
\hline & & Liver & & & & & 0.006 \\
\hline & & Bone & & & 19.0 & & \\
\hline $200 \mathrm{~B}-\mathrm{C}$ Crib & $8 / 29$ & Muscle & * & * & & $\star$ & \\
\hline & & Liver & & & & & 0.009 \\
\hline & & Bone & & & 6.9 & & \\
\hline Detection L & $i t^{(b)}$ & & 2.5 & 0.14 & 0.21 & 0.16 & 0.001 \\
\hline
\end{tabular}

* Less than detection limit.

(a) $10^{-6} \mu \mathrm{Ci} / \mathrm{g}=1 \mathrm{pCi} / \mathrm{g}$. A blank indicates that no analysis was made.

(b) The detection limit is the average of the individual detection limits for the less-than-detectabie results for each radionuclide.

Mice collected near a liquid waste trench in the 100-N Area have historically contained higher concentrations of radionuclides than those collected from any other location on the Hanford Site. (Screening over the trench prohibits access by larger animals.) Radionuclide concentrations in the mouse collected from the trench area in 1978 are typical of those measured in recent years (Table 9). Radioactivity in mice collected from several other areas indicates that radioactive materials are accessible but on a far lower scale than at the $100-\mathrm{N}$ trench. 
TABLE 9. Radionuclide Concentrations in Mice During 1978

\begin{tabular}{|c|c|c|c|c|c|c|c|c|c|}
\hline \multirow[b]{2}{*}{ Location } & \multirow[b]{2}{*}{ Species $^{(b)}$} & \multirow[b]{2}{*}{ Date } & \multicolumn{7}{|c|}{ Concentration, $10^{-6} u \mathrm{Ci} / \mathrm{g}$ Wet Weight ${ }^{\text {(a) }}$} \\
\hline & & & $54 \mathrm{Mn}$ & ${ }^{60} \mathrm{Co}$ & ${ }^{65} \mathrm{Zn}$ & ${ }^{90} \mathrm{Sr}$ & ${ }^{137} \mathrm{Cs}$ & $\underline{U}$ & $\begin{array}{l}\text { Total } \\
\mathrm{Pu} \\
\end{array}$ \\
\hline 100-F Area & $?$ & $3 / 03$ & $\star$ & $\star$ & $\star$ & & $\star$ & & \\
\hline 300 Area & PM & $3 / 03$ & $\star$ & $\star$ & $\star$ & 0.50 & $\star$ & 0.82 & $\cdot$ \\
\hline Gable Mtn. & PM & $3 / 10$ & $\star$ & $\star$ & $\star$ & 4.9 & 0.59 & & \\
\hline West Lake & PM & $3 / 10$ & $\star$ & $\star$ & $\star$ & 0.62 & $\star$ & & \\
\hline Redox & Mus M & $3 / 17$ & $\star$ & $\star$ & $\star$ & 14 & 44 & & \\
\hline BC Crib & $?$ & $3 / 24$ & $\star$ & $\star$ & $\star$ & 3.5 & * & & 0.006 \\
\hline U Plant & $?$ & $4 / 07$ & $\star$ & $\star$ & $\star$ & 4.4 & 3.3 & 0.03 & 0.03 \\
\hline$T$ Pond & PM & $4 / 07$ & * & * & $\star$ & 4.4 & 1.8 & & \\
\hline 100-N Trench & $\mathrm{PM}$ & $6 / 23$ & 362 & 1030 & 35 & 52 & 2920 & & \\
\hline 100-F Area & PM & $7 / 14$ & * & * & 0.5 & 260 & 1.6 & & \\
\hline$B$ Pond & Mus M & $8 / 18$ & * & * & $\star$ & 3.1 & 4.5 & & \\
\hline U Plant & Mus M & $8 / 18$ & * & $\star$ & * & 6.8 & 5.7 & 0.07 & 0.09 \\
\hline$T$ Pond & Mus M & $8 / 25$ & $\star$ & 0.6 & * & 3.1 & 9.9 & & \\
\hline Gable Mtn. & $\mathrm{PM}$ & $9 / 14$ & $\star$ & * & * & 0.37 & $\star$ & & \\
\hline 100-F Area & Mus $M$ & $9 / 14$ & $\star$ & * & * & 0.13 & $\star$ & & \\
\hline 300 Area & PM & $10 / 06$ & * & $\star$ & * & & 510 & 0.33 & \\
\hline$B-C$ Crib & $\mathrm{PP}$ & $10 / 06$ & * & * & * & 0.29 & * & & 0.005 \\
\hline Detection L & (c) & & 6 & 0.5 & 1.1 & 0.005 & 0.5 & 0.09 & 0.001 \\
\hline
\end{tabular}

* Less than detection limit.

(a) $10^{-6} \mu \mathrm{Ci} / \mathrm{g}=1 \mathrm{pCi} / \mathrm{g}$. A blank indicates that no analys is was made.

(b) PM - Peromyscus maniculatus (Deer Mouse). PP - Perognothus parvus (Great Bas in Pocket Mouse). Mus M - Mus musculus (House Mouse).

(c) The detection limit is the average of the individual limits for the less-thandetectable results for each radionuclide. 
Surface-soil and vegetation samples were collected during August 1978 from 21 locations both on and off the Hanford reservation at the sites shown in Figure 12. Details on the sample locations around operating areas are given in the Appendix. Each soil sample was a composite of five "plugs" of soil from an area approximately $100 \mathrm{~m}^{2}\left(1075 \mathrm{ft}^{2}\right)$. Each plug was approximately $2.5 \mathrm{~cm}(1 \mathrm{in.})$ in depth by $10 \mathrm{~cm}$ (4 in.) in diameter. The vegetation samples, collected in the vicinity of each soil sampling area, consisted of a representative collection of new growth from perennial vegetation, including rabbitbrush (Chrysothamnus spp.), bitterbrush (Purshia tridentata) and sagebrush (Artemisia tridentata). Both sets of samples were analyzed for gammaemitting radionuclides using a lithium-drifted germanium detector; for plutonium isotopes using radiochemical separation and alpha spectroscopy; and for ${ }^{90} \mathrm{Sr}$ using radiochemical techniques.

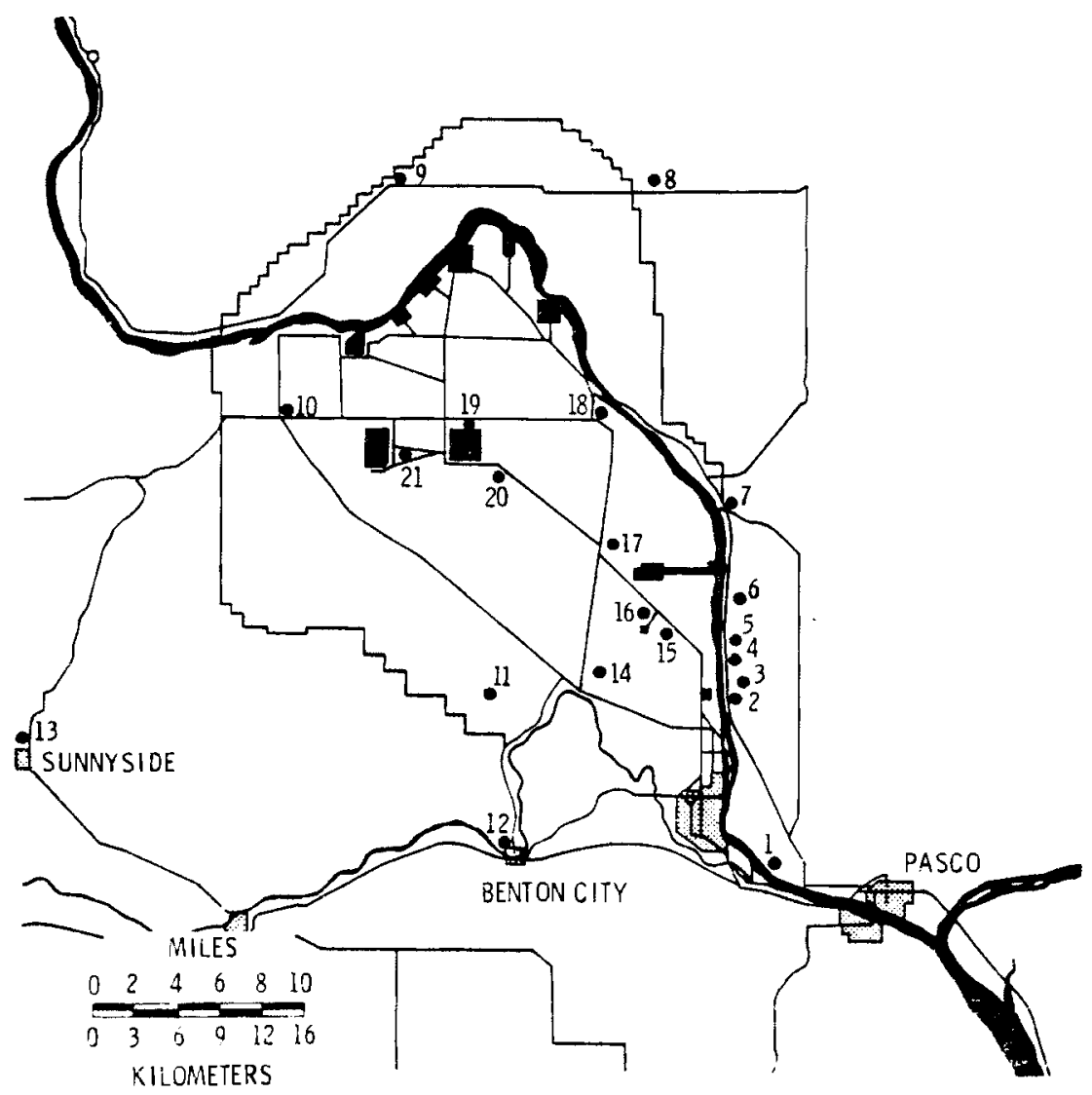

FIGURE 12. Soil and Vegetation Sampling Locations During 1978 
Surface soil and vegetation samples are collected to provide an indication of the cumulative buildup and distribution of radionuclides in the Hanford environment. Since some of the same radionuclides that are potentially released by Hanford activities are also present as a result of worldwide fallout from weapons testing, assessing the Hanford impact is difficult. One analytical tool that can be helpful in detecting the presence of a Hanford contribution to the environmental levels of radionuclides is probability plotting. This technique produces a straight line on a log plot if the concentrations are log-normally distributed and are produced by a single source such as worldwide fallout. Analys is of many background samples has shown that radionuclide concentrations in soil and vegetation are approximately log-normally distributed (Speer and Waite 1975; Miller, Fix and Bramson 1977). If the plotted concentrations describe two straight lines or if a few points at high cumulative probability fall significantly above a single straight line drawn through the rest of the data, Hanford activities may be contributing to the observed concentrations.

Analytical results for both on- and offsite soil samples are shown in Table 10. Several of the onsite samples contained ${ }^{90} \mathrm{Sr},{ }^{137} \mathrm{Cs}$, and $239-240 \mathrm{Pu}$ at unusual concentrations. Log-normal probability plots of the onsite soil sample data for these radionuclides, shown in Figures 13, 14, and 15 respectively, show graphically which values exceeded the concentrations generally attributed to worldwide fallout. Except for the ${ }^{90}$ Sr result from the Prosser Barricade sample, all results considered to be in excess of the worldwide fallout levels were obtained on samples taken from the vicinity of the 200 Areas. The relatively high ${ }^{137}$ Cs concentration observed at the 200 ENC location is similar to the concentration found in 1977, indicating that the deposition in this area is not new.

The results of vegetation sample analyses from on- and offsite locations are shown in Table 11 . Strontium-90, ${ }^{137} \mathrm{Cs}$, and ${ }^{239-240} \mathrm{pu}$ were found in vegetation samples from all sites at concentrations similar to those of previous years. The log-normal probability plots of the onsite data (see figures 13, 14, and 15) indicate that there may be a Hanford contribution at two or three sample locations: ${ }^{137} \mathrm{CS}$ at 200 ENC and at the ALE Field Lab, and 239-240 Pu at the Yakima Barricade. 
TABLE 10. Concentrations of Artificially Produced Radionuclides in Soil Samples During 1978

\begin{tabular}{|c|c|c|c|c|c|c|c|c|c|}
\hline \multirow{2}{*}{ Sample Location (b) } & \multirow[b]{2}{*}{$\operatorname{Map}_{\text {Location }}(c)$} & \multicolumn{8}{|c|}{ Concentration, $10^{-6} \cup \mathrm{Ci} / \mathrm{g}$ Dry Weight ${ }^{(a)}$} \\
\hline & & ${ }^{60} \mathrm{Co}_{0}$ & ${ }^{90} \mathrm{Sr}$ & ${ }^{95} \mathrm{ZrNb}$ & ${ }^{134} \mathrm{Cs}$ & ${ }^{137} \mathrm{Cs}_{\mathrm{s}}$ & ${ }^{144} \mathrm{Ce}$ & ${ }^{238} p_{u}$ & $239-240 P_{u}$ \\
\hline \multicolumn{10}{|l|}{ Onsite } \\
\hline Wahluke \#2 & 9 & * & 0.01 & 0.04 & 0.06 & 0.33 & 0.41 & * & 0.005 \\
\hline Yakima Barricade & 10 & $\star$ & 0.009 & * & * & 0.27 & 0.13 & $\star$ & 0.02 \\
\hline ALE Field Lab & 11 & * & 0.006 & 0.05 & 0.04 & 0.61 & 0.23 & * & 0.006 \\
\hline Prosser Barricade & 14 & * & 0.16 & * & 0.04 & 0.60 & 0.24 & * & 0.01 \\
\hline NE of FFTF & 15 & * & 0.04 & * & 0.05 & 0.14 & 0.22 & * & * \\
\hline SE of FFTF & 16 & * & 0.009 & * & 0.05 & 0.38 & 0.13 & 0.005 & 0.005 \\
\hline Wye Barricade & 17 & * & 0.04 & 0.06 & * & 0.60 & 0.42 & 0.002 & 0.006 \\
\hline Hanford Townsite & 18 & 0.04 & 0.03 & * & 0.04 & 0.34 & 0.47 & * & * \\
\hline 200 ENC & 19 & * & 0.70 & 0.05 & 0.03 & 1.6 & 0.18 & * & 0.01 \\
\hline 200 East $\mathrm{Hill}$ & 20 & * & 0.06 & 0.07 & 0.06 & 20 & 0.35 & * & 0.02 \\
\hline East of 200 West Area & 21 & 0.03 & $\underline{0.01}$ & $\star$ & $\star$ & 4.2 & 0.27 & 0.006 & 0.56 \\
\hline Average & & $<0.02$ & 0.10 & $<0.04$ & $<0.04$ & 2.7 & 0.28 & $<0.003$ & $<0.06$ \\
\hline \multicolumn{10}{|l|}{ Offsite } \\
\hline Harris Farm & 1 & * & 0.04 & * & * & 0.50 & * & * & 0.02 \\
\hline Byers Landing & 2 & * & 0.05 & 0.10 & * & 1.1 & * & 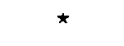 & * \\
\hline Sagemoor Farm & 3 & * & 0.008 & * & * & 0.12 & 0.25 & * & 0.003 \\
\hline Taylor Flats \#1 & 4 & 0.06 & 0.008 & 0.04 & 0.04 & 0.23 & 0.15 & 0.003 & 0.004 \\
\hline Taylor Flats \#2 & 5 & * & 0.007 & * & + & 0.09 & 0.42 & $\star$ & * \\
\hline West End of Fir Road & 6 & * & 0.01 & 0.04 & 0.05 & 0.39 & 0.38 & $\star$ & 0.004 \\
\hline Ringold & 7 & * & 0.03 & * & * & 0.97 & 0.41 & * & 0.02 \\
\hline Berg Ranch & 8 & * & 0.01 & 0.94 & 0.06 & 0.55 & 0.36 & * & 0.004 \\
\hline Benton City & 12 & * & 0.03 & 0.04 & 0.04 & 0.50 & 0.24 & $\star$ & 0.01 \\
\hline Sunnyside & 13 & $\star$ & $\underline{0.01}$ & 0.04 & $\star$ & 0.56 & 0.29 & $\star$ & 0.008 \\
\hline Average & & $<0.03$ & 0.02 & $\therefore 0.14$ & 0.03 & 0.50 & $<0.28$ & $<0.002$ & $<0.008$ \\
\hline Detection Limit ${ }^{(d)}$ & & 0.02 & 0.003 & 0.04 & 0.03 & 0.07 & 0.13 & 0.002 & 0.003 \\
\hline
\end{tabular}

* Less than detection limit.

(a) $10^{-6} \mu \mathrm{C} \mathrm{i} / \mathrm{g}=1 \mathrm{pC} \mathrm{i} / \mathrm{g}$.

(b) Sample location: ALE - Arid Lands Ecology. FFTF - Fast Flux Test Facility.

(c) See Figure 12.

(d) The detection limit is the average of the individual detection linits for the less-thandetectable results for each radionuclide.

The unusual radionuclide concentrations in soil and vegetation samples observed at onsite locations other than the 200 Areas are unsupported by other data and are considered to be spurious results at this time. 


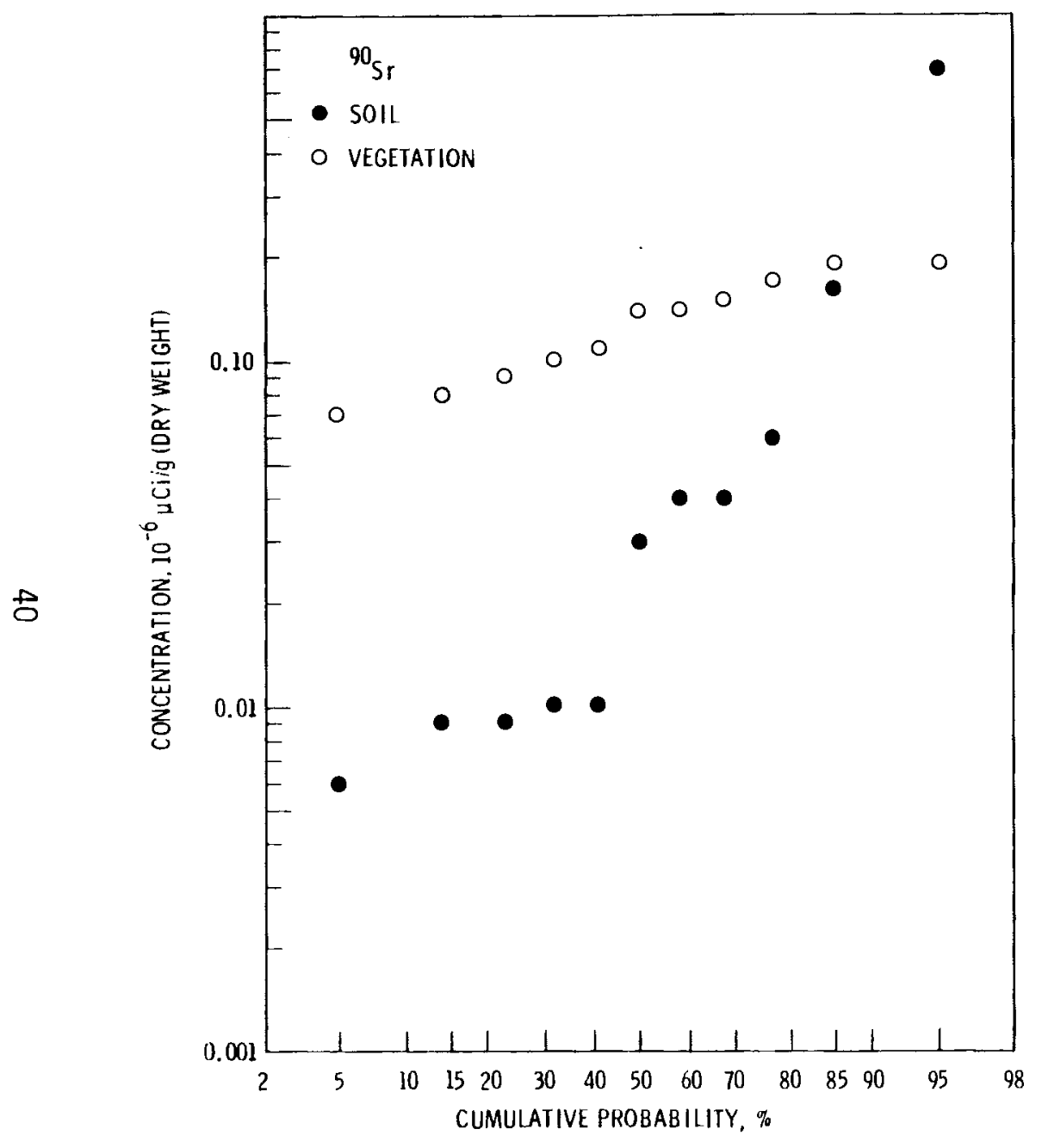

FIGURE 13. Log-Normal Probability Plot of ${ }^{90} \mathrm{Sr}$ in Soil and Vegetation

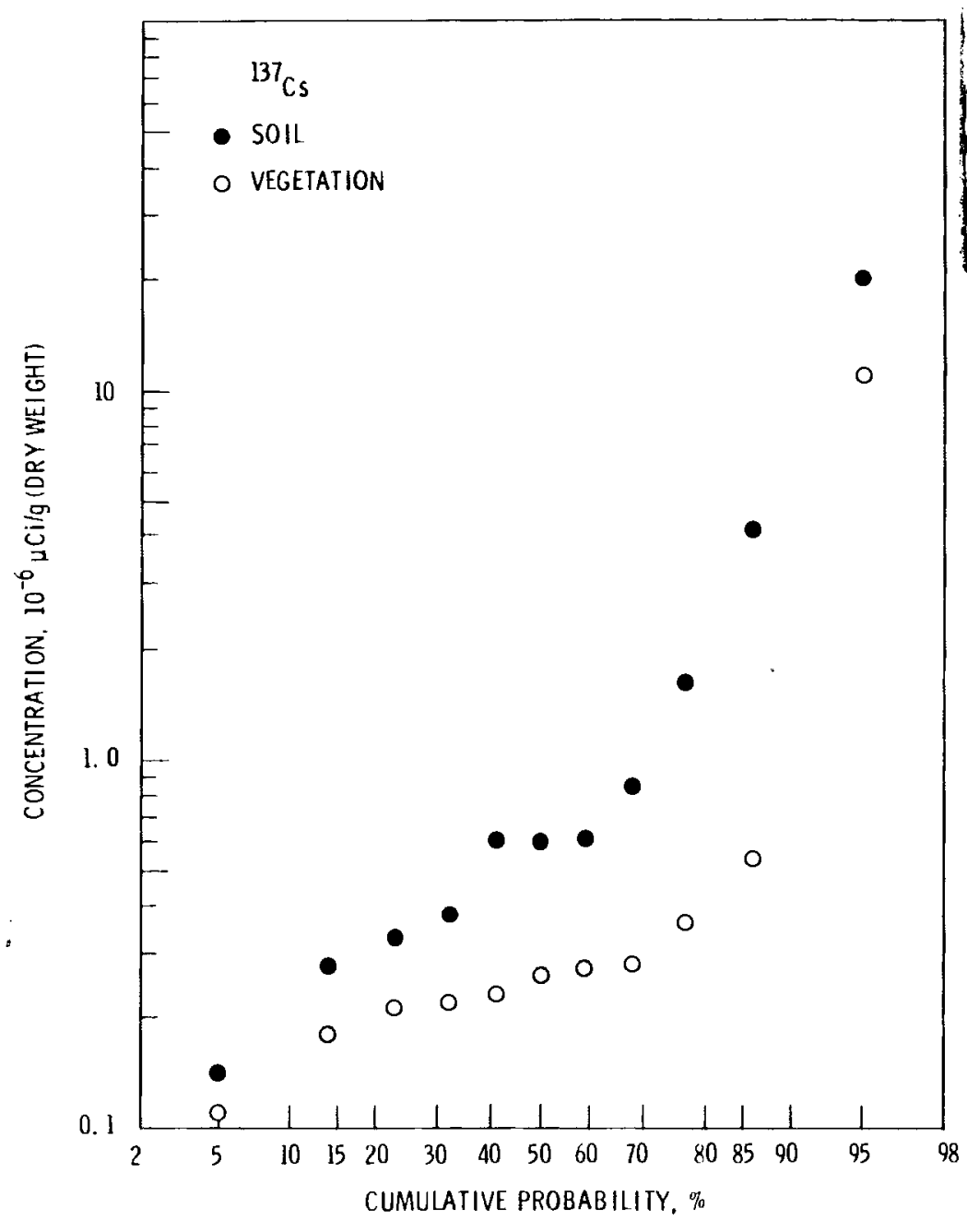

FIGURE 14. Log-Normal Probability Plot of ${ }^{137} \mathrm{Cs}$ in Soil and Vegetation 


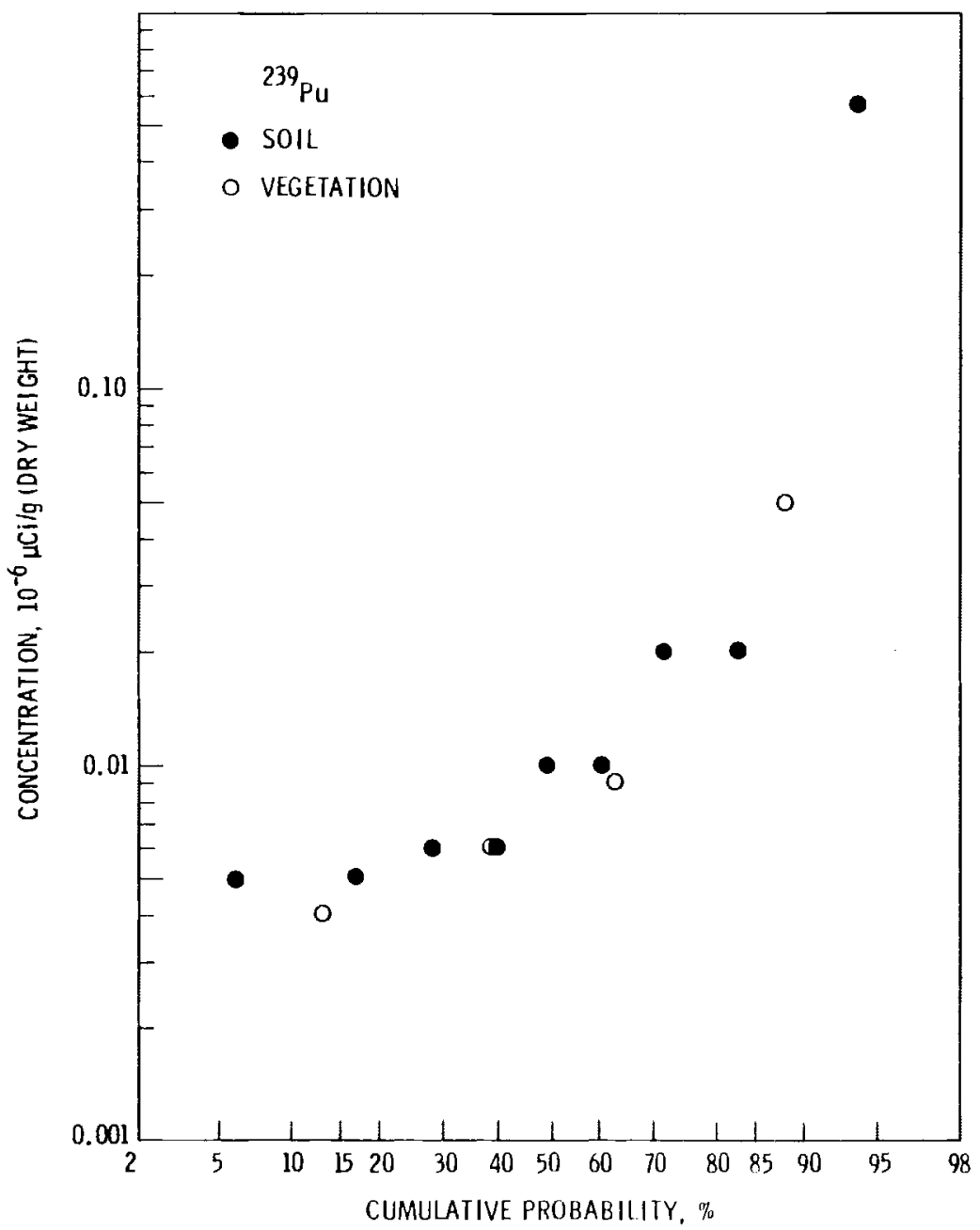

FIGURE 15. Log-Normal Probability Plot of $239-240 \mathrm{Pu}$ in Soil and Vegetation 
TABLE 11. Concentrations of Artificially Produced Radionuclides in Vegetation Samples During 1978

\begin{tabular}{|c|c|c|c|c|c|c|c|c|}
\hline \multirow[b]{2}{*}{ Sample Location (b) } & \multirow[b]{2}{*}{$\begin{array}{c}\text { Map } \\
\text { Location }(c) \\
\end{array}$} & \multicolumn{7}{|c|}{ Concentration, $10^{-6} \mu \mathrm{Ci} / \mathrm{g}$ Dry Weight (a) } \\
\hline & & ${ }^{60} \mathrm{Co}_{0}$ & $\underline{90} S r$ & ${ }^{95} \mathrm{ZrNb}$ & ${ }^{137} \mathrm{Cs}$ & ${ }^{144} \mathrm{Ce}$ & ${ }^{238} \mathrm{Pu}_{\mathrm{u}}$ & $239-240 P_{u}$ \\
\hline \multicolumn{9}{|l|}{ Onsite } \\
\hline Wahluke \#2 & 9 & $\star$ & 0.14 & 0.24 & 0.18 & 0.98 & $\star$ & 0.004 \\
\hline Yakima Barricade & 10 & $\star$ & 0.10 & $\star$ & 0.21 & 1.1 & $\star$ & 0.05 \\
\hline ALE Field Lab & 11 & $\star$ & 0.15 & * & 0.53 & 1.1 & * & $\star$ \\
\hline Prosser Barricade & 14 & $\star$ & 0.17 & $\star$ & 0.28 & $\star$ & $\star$ & $\star$ \\
\hline NE of FFTF & 15 & $\star$ & 0.08 & * & 0.22 & 1.3 & $\star$ & $\star$ \\
\hline SE of FFTF & 16 & $\star$ & 0.11 & $\star$ & 0.27 & 1.3 & $\star$ & $\star$ \\
\hline Wye Barricade & 17 & $\star$ & 0.14 & 0.12 & 0.11 & 0.85 & $\star$ & $\star$ \\
\hline Hanford Townsite & 18 & $\star$ & 0.09 & $\star$ & 0.23 & 1.0 & $\star$ & $\star$ \\
\hline 200 ENC & 19 & $\star$ & 0.19 & $\star$ & 11 & 1.1 & $\star$ & $\star$ \\
\hline 200 East $\mathrm{Hill}$ & 20 & 0.07 & 0.19 & 0.07 & 0.26 & 0.73 & * & 0.009 \\
\hline East of 200 West Area & 21 & $\star$ & $\underline{0.07}$ & $\star$ & 0.36 & 1.4 & $\star$ & 0.006 \\
\hline Average & & $<0.07$ & 0.13 & $<0.12$ & 1.2 & 1.0 & * & $<0.01$ \\
\hline \multicolumn{9}{|l|}{ Offsit? } \\
\hline Harr is Farm & 1 & * & 0.14 & 0.29 & 0.22 & 1.7 & $\star$ & 0.006 \\
\hline Byers Landing & 2 & $\star$ & 0.06 & $\star$ & 0.19 & 0.90 & $\star$ & 0.01 \\
\hline Sagemoor Farm & 3 & $\star$ & 0.03 & $\star$ & 0.26 & 0.50 & $\star$ & $\star$ \\
\hline Taylor Flats \#1 & 4 & $\star$ & 0.09 & * & $\star$ & 0.51 & * & $\star$ \\
\hline Taylor Flats \#2 & 5 & $\star$ & 0.03 & $\star$ & 0.25 & 1.1 & * & 0.006 \\
\hline West End of Fir Road & 6 & $\star$ & 0.05 & 0.13 & 0.23 & 1.2 & * & 0.004 \\
\hline Ringold & 7 & * & 0.06 & $\star$ & * & 0.62 & * & $\star$ \\
\hline Berg Ranch & 8 & * & 0.12 & * & 0.17 & 0.84 & * & 0.004 \\
\hline Benton City & 12 & * & 0.02 & 0.11 & 0.23 & 0.79 & $\star$ & $\star$ \\
\hline Sunnyside & 13 & $\star$ & $\underline{0.13}$ & $\stackrel{*}{\star}$ & 0.20 & $\underline{0.72}$ & $\star$ & $\star$ \\
\hline Average & & $\star$ & 0.07 & $<0.14$ & $<0.19$ & 0.89 & * & $<0.006$ \\
\hline Detection Limit ${ }^{(d)}$ & & 0.07 & 0.01 & 0.1 & 0.1 & 0.4 & 0.003 & 0.005 \\
\hline
\end{tabular}

* Less than detection limit.

(a) $10^{-6} \mu \mathrm{Ci} / \mathrm{g}=1 \mathrm{pCi} / \mathrm{g}$.

(b) Sample location: ALE - Arid Lands Ecology. FFTF - Fast Flux Test Facility.

(c) See Figure 12 .

(d) The detection limit is the average of the individual detection limits for the less-thandetectable results for each radionuclide. 


\section{EXTERNAL RADIATION}

Thermoluminescent dosimeters (TLDs) were used to measure the external dose at several onsite, perimeter, and distant locations, as shown in Figure 16. Detailed maps showing the locations of TLDs around each operating area are included in the Appendix. In general, the onsite dosimeters were located on the perimeter of each operating area. The dosimeters consisted of $\mathrm{CaF}_{2}: \mathrm{Mn}$ chips (Harshaw TLD-400) encased in an opaque plastic capsule lined

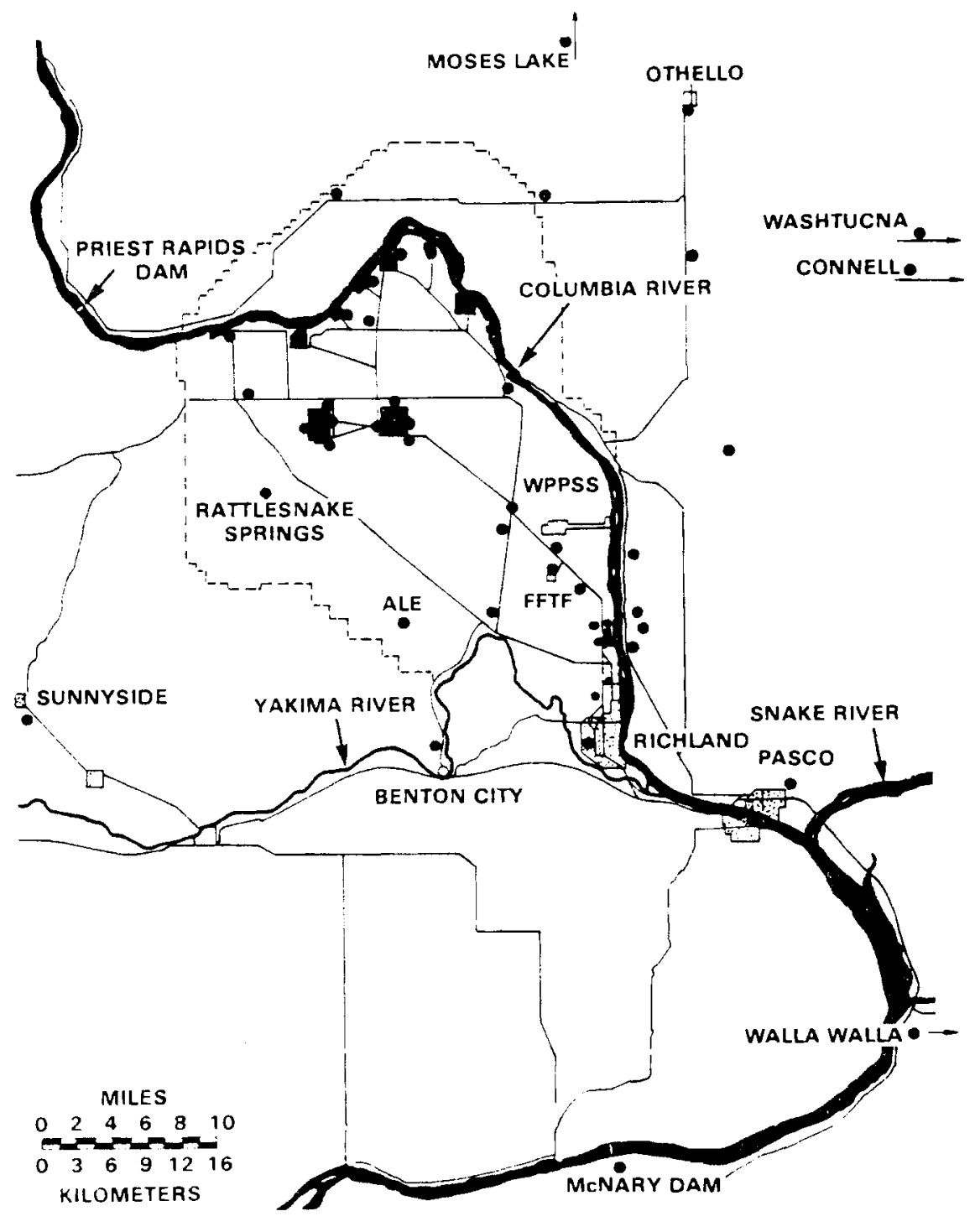

FIGURE 16. TLD Externa1 Dose Measurement Locations During 1978 
with $0.025 \mathrm{~cm}(0.01 \mathrm{in.})$ of tantalum and $0.005 \mathrm{~cm}(0.002$ in.) of lead to flatten the low-energy response ( $F i x$ and Miller 1978). The dosimeters were mounted approximately $1 \mathrm{~m}$ above ground level and changed monthly.

Shown in Table 12 are the results of the dose measurements made during 1978. Variability in the measured doses from different locations was expected, primarily because of spatial differences in the amount of natural radioactivity in the soil. The external dose measured at any location is affected by several parameters, including the height of the dosimeter above ground level, its elevation above sea level, the amounts of natural and worldwide fallout radionuclides in the area, and the presence of any radionuclides of Hanford origin.

A log-normal probability plot of the annual average dose rate for two groups of dosimeters is shown in Figure 17. The two groups represent onsite and offsite stations. Dose rates from both groups produced straight-line plots, although several higher dose rates were measured onsite, as expected, primarily around the $100-\mathrm{N}$ and 200 Areas. The straight-line plot for the offsite dose rates indicates that contributions from Hanford operations were indiscernible offsite.

From data in Table 12, the external background dose rate received by the population in the Hanford environs can be estimated. The average annual dose measured at the nonoperating area stations on the Hanford Site during 1978 was about $67 \mathrm{mrem}$ ( $1 \mathrm{mrem}$ equals $1 \mathrm{mrad}$ in this case). An additional $6 \mathrm{mrem}$ must be added to account for the neutron component of cosmic radiation (0akley 1972) and an additional 25 mrem must be added for the dose received from internal radionuclides in the human body, primarily ${ }^{40} \mathrm{~K}$ (U.S. Environmental Protection Agency 1972). The annual average background dose from all sources in the Hanford environs is thus about 100 mrem.

Environmental dosimeters were also submerged in the Columbia River at Coyote Rapids and the Richland Pumphouse (shown in Figure 18) to measure the dose potentially received by swimmers immersed in the Columbia River. Only two stations are currently monitored because dose rates measured in the river $(\sim 0.004 \mathrm{mrad} / \mathrm{hr})$ are currently about half of those on land. Data for these stations are shown in Table 13. 
TABLE 12. Results of TLD Measurements During 1978

\begin{tabular}{|c|c|c|c|c|c|}
\hline \multirow[b]{2}{*}{ Composite Group } & \multirow[b]{2}{*}{ Location (a) } & \multirow{2}{*}{$\begin{array}{c}\text { No. of } \\
\text { Measurements }\end{array}$} & \multicolumn{3}{|c|}{ Dose Rate, $\mathrm{mrad} / \mathrm{yr}$} \\
\hline & & & Maximum & Minimum & Average \\
\hline 100 Areas & $\begin{array}{l}100-K \\
100-N \\
100-D \\
100 \text { Area Fire station }\end{array}$ & $\begin{array}{l}13 \\
13 \\
13 \\
13\end{array}$ & $\begin{array}{r}77 \\
106 \\
88 \\
80\end{array}$ & $\begin{array}{l}51 \\
77 \\
66 \\
62\end{array}$ & $\begin{array}{l}62 \pm 15 \\
91 \pm 18 \\
73 \mp 11 \\
69 \pm 11\end{array}$ \\
\hline 200 East Area. & $\begin{array}{l}200 \text { ENC } \\
200 \text { EEC } \\
200 \text { ESE } \\
200 \text { EWC }\end{array}$ & $\begin{array}{l}13 \\
13 \\
13 \\
13\end{array}$ & $\begin{array}{r}190 \\
91 \\
88 \\
73\end{array}$ & $\begin{array}{r}128 \\
62 \\
62 \\
55\end{array}$ & $\begin{array}{r}157 \pm 40 \\
84 \pm 18 \\
73 \pm 15 \\
66 \pm 11\end{array}$ \\
\hline 200 West Area & $\begin{array}{l}200 \text { WNE } \\
200 \text { WEC } \\
\text { Redox } \\
200 \text { WWC }\end{array}$ & $\begin{array}{l}13 \\
13 \\
13 \\
13\end{array}$ & $\begin{array}{r}73 \\
77 \\
91 \\
172\end{array}$ & $\begin{array}{r}51 \\
58 \\
58 \\
124\end{array}$ & $\begin{array}{r}66 \pm 11 \\
69 \pm 11 \\
73 \pm 18 \\
146 \pm 26\end{array}$ \\
\hline 300 Area & $\begin{array}{l}300 \text { Pond } \\
3614-A \text { Bldg. } \\
300 \text { South Gate } \\
300 \text { Si Gate } \\
3705 \text { B 1dg. }\end{array}$ & $\begin{array}{l}13 \\
13 \\
13 \\
13 \\
13\end{array}$ & $\begin{array}{l}80 \\
73 \\
73 \\
73 \\
37\end{array}$ & $\begin{array}{l}62 \\
51 \\
51 \\
58 \\
77\end{array}$ & $\begin{array}{l}73 \pm 11 \\
65 \pm 11 \\
66 \pm 11 \\
59 \pm 7 \\
62 \pm 22\end{array}$ \\
\hline Inner Northeast Sector & $\begin{array}{l}\text { Berg Ranch } \\
\text { Wahluke Watermaster } \\
\text { Cooke Brothers } \\
\text { Othello } \\
\text { Conne } 1 \text { ? }\end{array}$ & $\begin{array}{l}13 \\
13 \\
13 \\
13 \\
13\end{array}$ & $\begin{array}{l}77 \\
69 \\
77 \\
66 \\
66\end{array}$ & $\begin{array}{l}40 \\
44 \\
47 \\
51 \\
55\end{array}$ & $\begin{array}{l}69 \pm 18 \\
66 \pm 15 \\
62 \pm 15 \\
55 \pm 7 \\
62 \pm 11\end{array}$ \\
\hline Inner East Sector & $\begin{array}{l}\text { Hanford } \\
\text { Wye Barricade } \\
\text { FFTF Site } \\
\text { FFTF North } \\
\text { FFTF Southeast } \\
\text { Rt } 10 \text {, Mile } 1.6\end{array}$ & $\begin{array}{l}13 \\
13 \\
13 \\
13 \\
13 \\
13\end{array}$ & $\begin{array}{l}73 \\
77 \\
77 \\
77 \\
77 \\
73\end{array}$ & $\begin{array}{l}51 \\
58 \\
51 \\
58 \\
58 \\
55\end{array}$ & $\begin{array}{l}62 \pm 15 \\
69 \mp 15 \\
69 \ddagger 15 \\
69 \pm 11 \\
69 \ddagger 11 \\
66 \pm 11\end{array}$ \\
\hline Inner Southeast Sector & $\begin{array}{l}\text { Fir Road } \\
\text { Pettett } \\
\text { Sagemoor } \\
\text { Byers Landing } \\
\text { Pasco } \\
\text { Richland } \\
1100 \text { Area } \\
\text { CP } \# 64\end{array}$ & $\begin{array}{l}13 \\
12 \\
12 \\
13 \\
13 \\
12 \\
13 \\
12\end{array}$ & $\begin{array}{l}84 \\
69 \\
80 \\
84 \\
77 \\
77 \\
84 \\
55\end{array}$ & $\begin{array}{l}40 \\
29 \\
44 \\
73 \\
62 \\
58 \\
51 \\
73\end{array}$ & $\begin{array}{l}66 \pm 13 \\
58 \pm 22 \\
69 \pm 18 \\
77 \pm 7 \\
66 \pm 11 \\
66 \pm 11 \\
66 \pm 22 \\
62 \pm 15\end{array}$ \\
\hline Inner Southwest Sector & $\begin{array}{l}\text { Prosser Barricade } \\
\text { Benton City } \\
\text { ALE Field Lab } \\
\text { Rattlesnake Springs }\end{array}$ & $\begin{array}{l}13 \\
13 \\
13 \\
13\end{array}$ & $\begin{array}{l}80 \\
69 \\
88 \\
77\end{array}$ & $\begin{array}{l}55 \\
44 \\
69 \\
55\end{array}$ & $\begin{array}{l}69 \pm 15 \\
58 \pm 11 \\
77 \pm 11 \\
69 \pm 7\end{array}$ \\
\hline Inner Northwest Sector & $\begin{array}{l}\text { Vernita } \\
\text { Yakima Barricade } \\
\text { Wahluke \#2 }\end{array}$ & $\begin{array}{l}13 \\
13 \\
13\end{array}$ & $\begin{array}{l}80 \\
84 \\
84\end{array}$ & $\begin{array}{l}51 \\
73 \\
55\end{array}$ & $\begin{array}{l}73 \pm 15 \\
77 \pm 7 \\
73 \pm 15\end{array}$ \\
\hline Outer Northeast Sector & $\begin{array}{l}\text { Moses Lake } \\
\text { Washtucna }\end{array}$ & $\begin{array}{l}13 \\
13\end{array}$ & $\begin{array}{l}69 \\
69\end{array}$ & $\begin{array}{l}51 \\
55\end{array}$ & $\begin{array}{l}62 \pm 11 \\
62 \pm 11\end{array}$ \\
\hline Outer Southeast Sector & $\begin{array}{l}\text { Walla Walla } \\
\text { McNary }\end{array}$ & $\begin{array}{l}13 \\
13\end{array}$ & $\begin{array}{l}88 \\
77\end{array}$ & $\begin{array}{l}44 \\
58\end{array}$ & $\begin{array}{l}62 \pm 22 \\
65 \pm 15\end{array}$ \\
\hline Outer West Sector & Sunnyside & 13 & 69 & 55 & $62 \pm 11$ \\
\hline
\end{tabular}

(a) Location: FFTF - Fast Flux Test Facility. ALE - Arid Lands Ecology. 


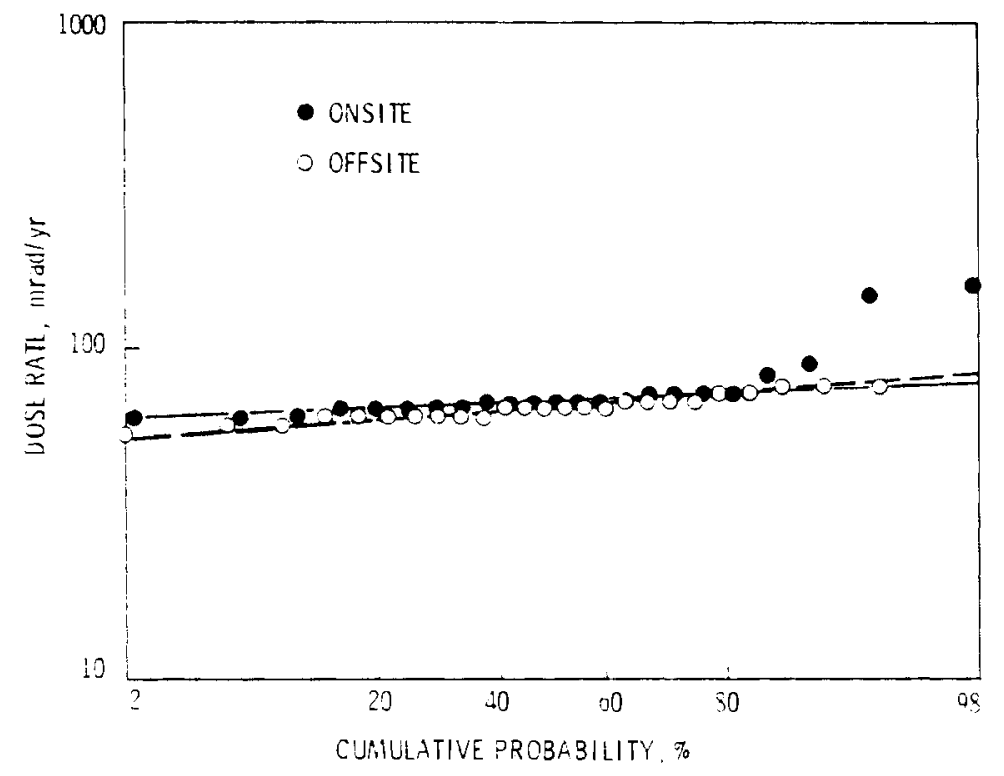

FIGURE 17. Log-Normal Probability Plot of TLD External Dose Measurements

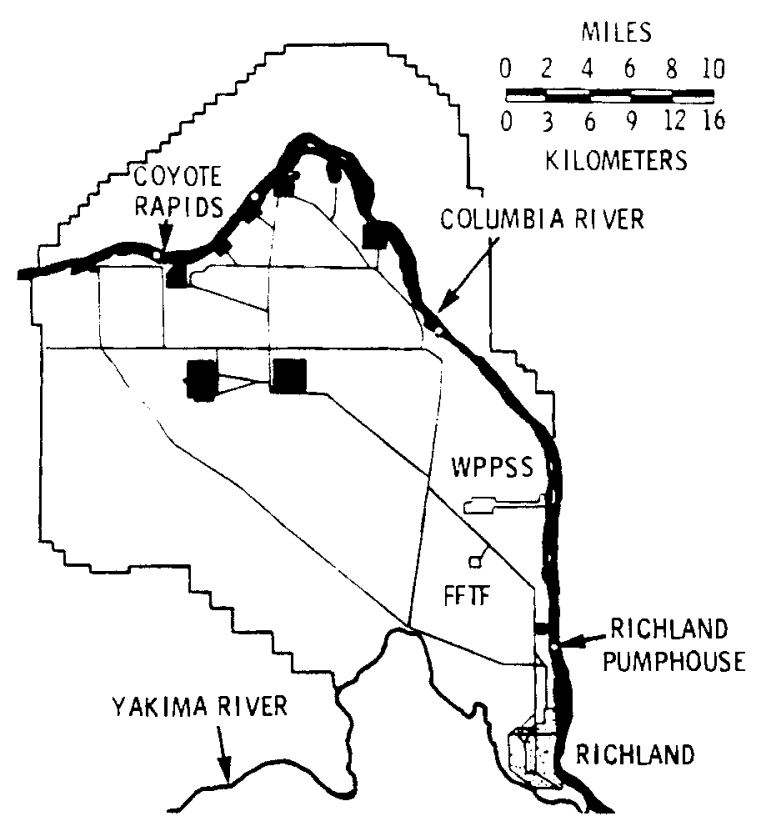

FIGURE 18. Locations of Immersion Dose Measurements in the Columbia River During 1978

In the past, analyses of sediment samples collected along the Columbia River and surveys made with portable radiation detection instruments have revealed the presence of a few long-lived radionuclides, primarily ${ }^{60}$ Co. This activity, released to the river during past operation of the once-through- 
TABLE 13. Columbia River Immersion Dose Rates During 1978

\begin{tabular}{|c|c|c|c|c|}
\hline \multirow[b]{2}{*}{ Location } & \multirow{2}{*}{$\begin{array}{c}\text { No. of } \\
\text { Measurements } \\
\end{array}$} & \multicolumn{3}{|c|}{ Dose Rate, $\mathrm{mrad} / \mathrm{yr}$} \\
\hline & & Maximum & Minimum & Average \\
\hline & 10 & 40 & 29 & $36 \pm 14$ \\
\hline Richland Pumphouse & 13 & 37 & 22 & $31 \pm$ \\
\hline
\end{tabular}

cooled production reactors, was deposited on many of the river's islands and on the shoreline and slough areas along the Hanford reach, and remains there slowly decaying (Fix 1976). Summarized in Table 14 are TLD measurements of external radiation taken at 12 locations along the Columbia River shoreline and at 3 of the larger islands during 1978. These locations are shown in Figure 19. The variation in dose rates among the locations is due to differences in ${ }^{60}$ Co concentrations.

The maximum external dose rate along the river was measured at the $100-\mathrm{N}$ trench springs and corresponds to a dose rate of $0.075 \mathrm{mrad} / \mathrm{hr}$ averaged over a 1-month period, or about 10 times the average background dose rate at Hanford. Slightly contaminated water seeping from the springs is probably responsible for the dose rate at this location.

TABLE 14. Dose Rate Measurements Along the Columbia River Islands and Shoreline During 1978

\begin{tabular}{|c|c|c|c|c|}
\hline \multirow[b]{2}{*}{ Location } & \multirow{2}{*}{$\begin{array}{c}\text { No. of } \\
\text { Measurements }\end{array}$} & \multicolumn{3}{|c|}{ Dose Rate, $\mathrm{mrad} / \mathrm{yr}$} \\
\hline & & Maximum & Minimum & Average \\
\hline Above $100-K$ Area & 13 & 80 & 62 & $71 \pm 12$ \\
\hline 100-N Trench Springs & 13 & 660 & 280 & $430 \pm 230$ \\
\hline Opposite 100-D Area & 13 & 69 & 51 & $63 \pm 11$ \\
\hline Locke Is land & 13 & 84 & 69 & $76 \pm 11$ \\
\hline White Bluffs & 13 & 84 & 66 & $73 \pm 12$ \\
\hline Below 100-F Area & 12 & 77 & 58 & $68 \pm 13$ \\
\hline Hanford Powerline Crossing & 13 & 88 & 58 & $75 \pm 16$ \\
\hline Hanford Ferry Landing & 9 & 88 & 55 & $75 \pm 21$ \\
\hline Hanford RR Track & 13 & 150 & 100 & $120 \pm 32$ \\
\hline Ringold Island & 13 & 77 & 66 & $73 \pm 11$ \\
\hline Powerline Crossing & 13 & 99 & 62 & $82 \pm 20$ \\
\hline Wooded Is land & 13 & 88 & 62 & $76 \pm 21$ \\
\hline
\end{tabular}




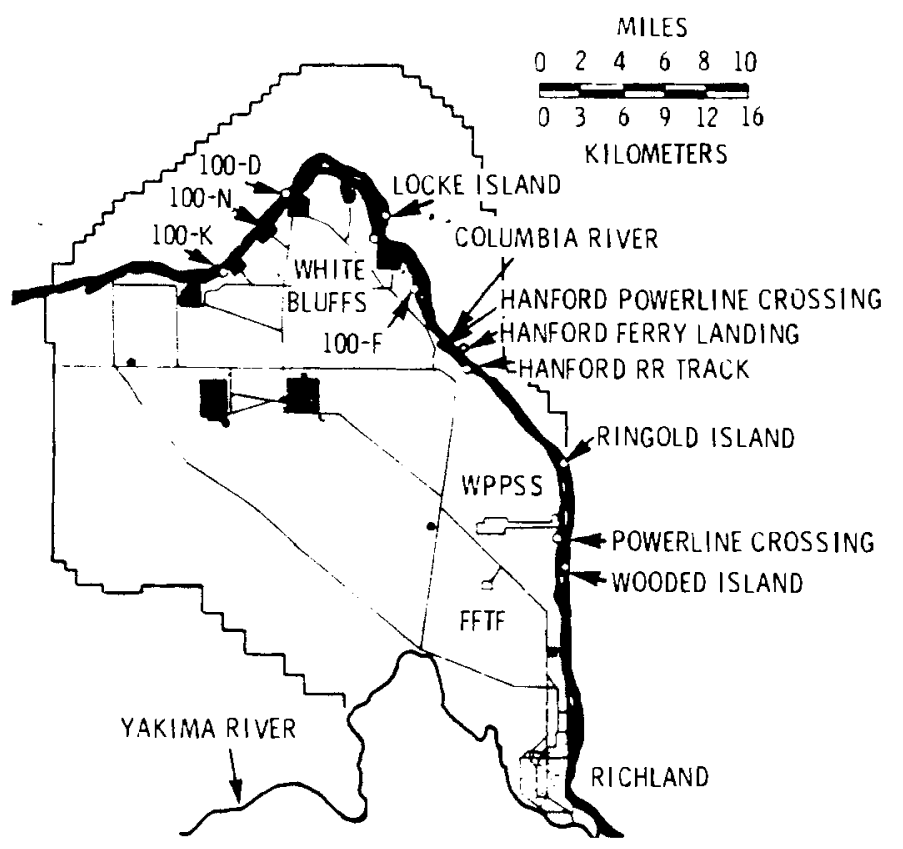

FIGURE 19. Locations of External Dose Measurements Along the Columbia River During 1978 


\section{RADIATION SURVEYS}

The Hanford environmental surveillance program includes the surveillance of roads, railways, and waste disposal sites to detect any abnormal levels of radioactivity. During the summer of 1978, an aerial radiation survey of the Hanford operating areas and waste sites and the Hanford reach of the Columbia River was conducted. The results of this survey, conducted by an outside contractor, were not available in time to be included in this report.

\section{HANFORD ROADS SURVEY}

Roads on the Hanford Site were routinely surveyed during 1978 with a scintillation detector attached to the right front end of a truck and positioned about $0.3 \mathrm{~m}(1 \mathrm{ft})$ above the road surface. The road monitor has been described in BNWL-62 (Philipp and Sheen 1965). Survey frequency ranged from monthly to quarterly, depending on road usage and contamination potential, with most roads surveyed monthly. During 1978, no conditions requiring corrective action were detected.

\section{RAILROAD SURVEY}

A11 Hanford railroad tracks outside of the operating area fences were surveyed either quarterly or annualiy. The survey was conducted using a road monitor attached to a railroad maintenance car. No conditions requiring corrective action were detected.

\section{WASTE DISPOSAL SITES}

Active, inactive, and retired sites for waste disposal were surveyed and inspected for general physical condition during 1978. A list of these sites and the survey frequency may be found in the Master Schedule for $\mathrm{CY}-1978$ (BTumer, Houston and Eddy 1978). Most sites were surveyed semiannualiy. Except for a few instances of animal burrowings, minor subsidences, and housekeeping problems, the sites were found to be in good condition. Unusual radiation levels and conditions, if any, were noted during each survey and reported to the responsible contractor representative for corrective action. 


\section{ENVIRONMENTAL RELEASES}

For the purposes of this report, anything disposed of to the environment is considered an environmental release. These releases can result either from the planned day-to-day operation of facilities or from accidents or unusual occurrences. Temporary storage of materials or wastes in an engineered facility is not considered an environmental release.

Both routine and accidental releases to the environment can be further subdivided into groups with similar dispersion characteristics, such as gaseous, liquid, and solid wastes. Within these groups, contaminants can be classified by their nature, e.g., radioactivity, chemicals, particulates, heat, and sewage.

Monitoring and sampling programs are conducted routinely by each Hanford contractor to help assure that adequate controls of processes and effluent streams are maintained.

\section{ROUTINE RELEASES}

Routine releases are those expected as a matter of course during the operation of a facility, such as ventilation exhausts and cooling water discharges. They arise out of the basic design of the facility and are regulated by effluent control systems and other factors providing containment of waste materials. Routine releases of waste materials from Hanford facilities are generally consistent with those expected based on the facilities' design.

\section{Gaseous Effluents}

Gaseous effluents are primarily filtered air from building ventilation systems, process gas streams treated by various means such as scrubbers, chemical reactors, and filters, and the exhaust gases from steam power plants. Contaminants in gaseous effluents at the Hanford Site include radioactive materials, various chemical compounds, and particulates.

Radionuclide concentrations in routine gaseous effluents at Hanford have been rather low, particularly in recent years. Operations at $N$ Reactor 
currently produce the bulk of the activity released to the atmosphere. Most of this activity, however, is made of up short-lived radionuclides. The total quantities of radionuclides released to the air from each operating area during 1978 are shown in Table 15.

The nonradioactive pollutants in Hanford's routine gaseous effluents consist primarily of oxides of sulfur from the steam power plants, oxides of nitrogen from chemical processes and steam power plants, and particulates. Smaller quantities of other pollutants such as carbon monoxide, hydrocarbons, aldehydes, and a number of other materials are also released.

The nonradioactive pollutant content of gaseous effluents for 1978 is shown in Table 16. The data in this table are not complete because effluent streams are generally not sampled for nonradioactive pollutants. In most cases the values are calculated from the quantities of the material used (in the case of volatile materials) or burned (in the case of fuel oil and coal).

\section{Liquid Effluents}

Liquid effluents consist of the large volumes of water used for processing and cooling during routine operations. Contaminants in liquid effluents may include low concentrations of radioactive and chemical constituents, suspended particulates, heat, and oil or grease.

Discharges to the Columbia River

Hanford Site waste waters are discharged at nine points along the Hanford reach of the Columbia River. These discharges, within certain limits, are allowed under the National Pollutant Discharge Elimination System (NPDES) permit. Sources of these discharges are backwash water from intake screens, cooling water, overflow from water storage tanks, and fish hatchery waste water.

Summarized in Table 15 are the quantities of radionuclides discharged to the river during 1978. The majority of this activity reaches the river via the 1301-N Crib (Greager 1979).

Chemical pollutants in liquid discharges to the river consist primarily of sulfate ion and small quantities of hydrazine and morpholine. Suspended 
TABLE 15. Routine Radionuclide Releases to the River and the Atmosphere During 1978

\begin{tabular}{|c|c|c|c|c|c|}
\hline \multirow[b]{2}{*}{ Radionuclide } & \multirow[b]{2}{*}{ Haif Life } & \multirow{2}{*}{$\begin{array}{l}\text { Liquid } \\
\text { To River }\end{array}$} & \\
\hline & & & 100 Areas & $\begin{array}{l}\text { Gaseous } \\
200 \text { Areas }\end{array}$ & 300 Area \\
\hline${ }^{3} \mathrm{H}(\mathrm{HTO})$ & $12.3 \mathrm{yr}$ & 330 & 31. & $\cdots$ & 0.046 \\
\hline${ }^{24} \mathrm{Na}$ & $15 \mathrm{hr}$ & & 0.20 & -- & -- \\
\hline $\begin{array}{l}32 \mathrm{p} \\
41 \mathrm{Ar}\end{array}$ & $14.3 \mathrm{~d}$ & 0.03 & $11 \times 105$ & -- & -- \\
\hline $\begin{array}{l}{ }^{1} \mathrm{Ar} \\
51 \mathrm{Cr}\end{array}$ & $1.8 \mathrm{hr}$ & & $1.1 \times 10^{5}$ & -- & -- \\
\hline $54 \mathrm{Mn}$ & $27.8 \mathrm{~d}$ & 0.14 & 0.046 & -- & -- \\
\hline $56 \mathrm{Mn}$ & 303 & 0.18 & 0.021 & -- & -- \\
\hline $59 \mathrm{Fe}$ & $\begin{array}{l}2.6 \mathrm{hr} \\
46 \mathrm{~d}\end{array}$ & $\begin{array}{l}1.2 \\
0.11\end{array}$ & $\begin{array}{l}3.8 \\
0.022\end{array}$ & -- & -- \\
\hline $58 \mathrm{Co}$ & $71 d$ & 0.032 & $\begin{array}{l}.022 \\
0.019\end{array}$ & -- & $\begin{array}{l}-- \\
--\end{array}$ \\
\hline $60 \mathrm{co}$ & $5.3 \mathrm{yr}$ & 0.96 & 0.038 & -- & $4.7 \times 10^{-5(a)}$ \\
\hline${ }^{65} \mathrm{Zn}$ & $245 d$ & -- & 0.012 & -- & -- \\
\hline & $26.4 \mathrm{hr}$ & -- & 6.7 & -- & -- \\
\hline $\begin{array}{l}82 \mathrm{Br} \\
85 \mathrm{~m}_{\mathrm{k}}\end{array}$ & $35 \mathrm{hr}$ & -- & 0.013 & - & -- \\
\hline $\begin{array}{l}85 \mathrm{~m}_{\mathrm{kr}} \\
85 \mathrm{kr}\end{array}$ & $4.4 \mathrm{hr}$ & -- & 510 & -- & - \\
\hline $85 \mathrm{kr}$ & $10.8 \mathrm{hr}$ & -- & - & -- & 440 \\
\hline $\begin{array}{l}88 \mathrm{kr} \\
88 \mathrm{kr}\end{array}$ & $76 \mathrm{~m}$ & -- & 1540 & -- & - \\
\hline $\begin{array}{l}88_{k r R b} \\
89_{<r}\end{array}$ & $2.8 \mathrm{hr}$ & $\because \mathrm{r}$ & 1180 & -- & - \\
\hline $\begin{array}{l}89 S r \\
90 \mathrm{Sr}\end{array}$ & $\begin{array}{l}52.7 \mathrm{~d} \\
27.7 \mathrm{yr}\end{array}$ & $\begin{array}{l}0.40 \\
1.3\end{array}$ & $7.2 \times 10^{0.021}$ & $0 . \bar{j}(b)$ & $1.1 \times 10^{-4}(b)$ \\
\hline $915 \mathrm{~s} r$ & $9.7 \mathrm{hr}$ & & 0.95 & - & \\
\hline${ }_{95}^{95} \mathrm{Zr}$ & $65.5 \mathrm{~d}$ & 0.11 & 0.0078 & -- & -- \\
\hline $\begin{array}{l}95 \mathrm{Nb} \\
977 \mathrm{rt}\end{array}$ & 35 & 0.16 & 0.0073 & -- & -- \\
\hline & & -- & 0.011 & -- & -- \\
\hline & $66.7 \mathrm{hr}$ & 2.6 & 1.0 & -- & -- \\
\hline $103_{\mathrm{RL}}$ & $39.5 \mathrm{hr}$ & 0.38 & 0.017 & -- & -- \\
\hline 106 & $368 d$ & 0.57 & 0.060 & -- & -- \\
\hline & $2.8 \mathrm{~d}$ & -- & 0.0054 & ..- & -- \\
\hline 124 & $60.4 \mathrm{~d}$ & 0.062 & 0.003 & -- & -- \\
\hline 125 & $2.7 \mathrm{yr}$ & 0.17 & $3.0 \times 10^{-4}$ & -. & -- \\
\hline & $77.7 \mathrm{hr}$ & -- & 0.025 & -- & -- \\
\hline 125 & $1.7 \times 10^{7} \mathrm{yr}$ & $8.2 \times 10^{-6}$ & - & -- & $5.8 \times 10^{-4}$ \\
\hline 131 & $8.1 \mathrm{~d}$ & 4.8 & 0.47 & -- & $3.5 \times 10^{-4}$ \\
\hline & $2.3 \mathrm{hr}$ & $-\infty$ & 6.2 & -- & -- \\
\hline & $20.3 \mathrm{hr}$ & 0.95 & 3.1 & -- & -- \\
\hline & 6.7 & -- & 6.2 & -- & -- \\
\hline & $5.3 \mathrm{~d}$ & 5.7 & 91 & -- & -- \\
\hline & 2.3 & -- & 1.6 & -- & -- \\
\hline & 9.1 & -- & 2120 & -- & -- \\
\hline & $17.5 \mathrm{~min}$ & -- & 5040 & -- & -- \\
\hline & $2.1 \mathrm{gr}$ & -- & $9.8 \times 10^{-4}$ & -- & -- \\
\hline & 30.0 & 0.031 & 0.0023 & -- & -- \\
\hline & & 0.38 & 0.19 & -- & -- \\
\hline & $40.2 \mathrm{hr}$ & 4.0 & 1.1 & -- & -- \\
\hline & $32.5 \mathrm{~d}$ & 0.035 & 0.0074 & -- & -- \\
\hline & 284 & 0.15 & 0.0 & -- & -- \\
\hline & & 0.17 & 0.0 & -- & -- \\
\hline & 46.8 & -- & 0.028 & -- & - \\
\hline 15 & & 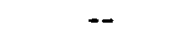 & 0.032 & -- & -- \\
\hline & & -- & 0.071 & -- & -- \\
\hline 187 & $23.9 \mathrm{hr}$ & -- & 0.34 & -- & $\ddot{m}$ \\
\hline & & -- & -- & -- & 0.009 \\
\hline U-Nat. & $4.4 \times 10^{9} \mathrm{yr}$ & -- & - & -- & $4.0 \times 10^{-5}$ \\
\hline${ }^{239} \mathrm{~Np}$ & $2.3 \mathrm{~d}$ & & & -- & -- \\
\hline $\begin{array}{l}{ }^{238} \mathrm{Pu} \\
239 \mathrm{Pu}\end{array}$ & $\begin{array}{l}86.4 \mathrm{yr} \\
2.44 \times 10^{-4} \mathrm{rr}\end{array}$ & $\begin{array}{c}1.3 \times 10^{-4} \\
0.085\end{array}$ & $\begin{array}{l}3.6 \times 10^{-1} \\
2.2 \times 10^{-6}\end{array}$ & $0 . \overline{0013}(c)$ & $2.8 \times 10^{-5}(\mathrm{c})$ \\
\hline & $2.44 \times 10-5 \mathrm{gr}$ & 0.085 & $2.6 \times 10-0$ & & \\
\hline
\end{tabular}

(a) Actually reported as mixed activation products. Cobalt-60 was assumed for simplicity and was used in dose calculations.

(b) Actualily reported as mixed fission products. Strontium-90 was assumed for simplicity and was used in dose calculations.

(c) Actually reported as gross alpha. Plutonium-239 was assumed for simplicity and was used in dose calculations.

-- Radionuclide not reported in effluent. 
TABLE 16. Nonradioactive Pollutants in Hanford Gaseous Effluents During 1978

\begin{tabular}{|c|c|c|c|}
\hline \multirow{2}{*}{ Pollutant } & \multicolumn{3}{|c|}{ Quantity Released, $\mathrm{kg}$} \\
\hline & 100 Areas & 200 Areas & 300 Area \\
\hline Sulfur dioxide & 495,000 & 910,000 & 30,500 \\
\hline Sulfur trioxide & 6,610 & -- & -- \\
\hline Carbon monoxide & 8,200 & N.A. & N.A. \\
\hline Hydrocarbons & 6,080 & N.A. & N.A. \\
\hline Nitrogen oxides & 168,000 & N.A. & 8,900 \\
\hline Aldehydes & 2,250 & N.A. & N.A. \\
\hline Trichloroethylene & -- & -- & 9,300 \\
\hline Perch Toroethylene & -- & - & 13,500 \\
\hline 1,1,1-trichloroethane & -- & -- & 1,080 \\
\hline Particulates & 51,400 & N.A. & 3,100 \\
\hline
\end{tabular}

solids are also discharged back into the river during intake screen and filter backwash operations. The large volumes of water used in the cooling of $\mathrm{N}$ Reactor result in about $5.7 \times 10^{11}$ liters $\left(1.5 \times 10^{11}\right.$ gallons $)$ of heated water being discharged to the river each year.

Discharges to the Soil

Large quantities of water are used in operations at Hanford and disposed of to the soil on site. The bulk of this water is used for cooling purposes and never comes in contact with radioactive or hazardous chemicals. Waste water from these uses is discharged to surface ponds for evaporation and/or percolation.

Other water either is contaminated during routine operations or has a reasonable likelihood of being contaminated in the event of equipment malfunction or process upset. These waste waters are disposed of in controlled 
ditches, trenches, and cribs in such a manner as to take advantage of the favorable ion exchange characteristics of the soil in removing contaminants from the water.

Nonradioactive effluents to soil during 1978 consisted of liquid process waste, power house wastes (coal ash slurry), laboratory chemical waste, filter backwash from water treatment plants, demineralizer wastes, and sanitary sewage. Routine discharges of waste water to the soil during 1978 were as follows:

100-N Area. About 4.6 billion liters (1.2 billion gallons) of primary coolant bleed water and coolant water from $N$ Reactor's fuel storage basin contaminated with 58,000 curies ( $\mathrm{C} i$ ) of fission and activation product radionuclides were disposed of to the 1301-N crib (Greager 1979). The majority of this activity is made up of short-lived radionuclides. Less than $1 \%$ of the activity discharged to this crib reaches the Columbia River. Most of it either decays or sorbs on to soil particles as it passes through the soil.

100-K Area. During 1978, about 13 million liters (3.4 million gallons) of water from the KE Reactor's fuel storage basin were released to the soil. This basin was converted from its original purpose several years ago and now serves as a temporary storage basin for spent fuel from $N$ Reactor. Basin coolant water released at a rate of about 29 liters per minute $(7.5$ gallons per minute) resulted in a total of $1140 \mathrm{C} i$ of fission and activation product radionuclides being discharged to the soil beneath the basin in 1978. (a) Most of this radioactivity is retained on the soil particles in the immediate vicinity of the basin and will not reach the river. Studies have shown that the $\mathrm{Pu}, \mathrm{Cs}$, and $\mathrm{Sr}$ activity is retained in the soil column (Dorian and Richards 1978). The only radionuclide expected to reach the river is about $9.5 \mathrm{Ci}$ of tritium.

200 East Area. Cooling water and steam condensate containing less than $15 \mathrm{Ci}$ of radionuclides in 16 billion liters ( 4.2 billion gallons) of water

(a) Personal communication with L.K. Poppe, UNC Nuclear Industries. 
were discharged to various ponds, ditches, and trenches in 1978. Another $174 \mathrm{Ci}$ in 240 million liters (63 million gallons) of process and steam condensate water were disposed of to various cribs in the 200 East Area (Anderson and Poremba 1979a).

200 West Area. About $1.1 \mathrm{C} i$ of radionuclides in 6.8 billion liters ( 1.8 billion gallons) of cooling water, steam condensate, and other low-level contaminated waste water were disposed of to a number of ditches, trenches, and surface ponds. Another 11 curies in 14 million liters ( 3.7 million gallons) of process and steam condensate waste water were disposed of to various cribs in the 200 West Area.

300 Area. Process trenches in the 300 Area received 1.9 billion liters (500 million gallons) of process waste water containing $288 \mathrm{~kg}$ (634 1b) of uranium, $882 \mathrm{~kg}$ (1940 1b) of copper, $1718 \mathrm{~kg}(3780 \mathrm{lb})$ of fluoride, $227 \mathrm{~kg}$ (500 1b) of zinc, $0.5 \mathrm{~kg}$ (1 1b) of mercury, 32,300 kg (71,000 1b) of nitrate, and a total of less than $1 \mathrm{C} i$ of radioactivity. Sanitary trenches received 460 million liters (120 million gallons) of laboratory, animal, and other wastes containing $1 \mathrm{~kg}(2.5 \mathrm{lb})$ of uranium, $11 \mathrm{~kg}(23 \mathrm{lb})$ of copper, $59 \mathrm{~kg}$ (130 1b) of fluoride, $55 \mathrm{~kg}(120 \mathrm{lb})$ of zinc, $0.05 \mathrm{~kg}(0.1 \mathrm{lb})$ of mercury, $1860 \mathrm{~kg}(4100 \mathrm{lb})$ of nitrate, and about $0.2 \mathrm{Ci}$ of radioactivity. (a)

Solid Wastes

Solid wastes include a wide variety of materials, from ordinary trash to large pieces of contaminated equipment. Contaminants in Hanford's solid wastes include radioactivity, and hazardous chemicals and substances. All solid wastes are buried in trenches or landfills in or near the 200 Areas.

Some solid wastes are contaminated to varying degrees with the many forms of radioactive materials generated at Hanford. These materials consist of fission products, induced radionuclides, uranium, and transuranic elements, principally plutonium. Solid waste containing ${ }^{233} \mathrm{U}$ or transuranic elements is packaged and buried separately from nontransuranic radionuclide waste for

(a) Personal communication with J.M. McCarthy, Westinghouse Hanford Company. 
future retrieval. Other radioactively contaminated solids are packaged in boxes, drums, or other containers and buried underground in trenches. The quantities of these radioactively contaminated solid wastes buried during 1978 are shown in Table 17 (Anderson and Poremba 1979b).

Other solid wastes produced during 1978 included general wastes or sanitary landfill, hazardous chemicals, and asbestos. The quantities of these waste materials buried are shown in Table 17.

TABLE 17. Hanford Solid Waste Effluents During 1978

\begin{tabular}{lc}
\multicolumn{1}{c}{ Waste Type } & Quantity \\
\cline { 1 - 1 } Radioactive Waste & \\
$\quad$ Uranium & $5.4 \times 10^{6} \mathrm{~g}$ \\
Plutonium & $5.8 \times 10^{3} \mathrm{~g}$ \\
Other transuranics & $9.7 \times 10^{4} \mathrm{~g}$ \\
Strontium-90 & $1.1 \times 10^{5} \mathrm{Ci}$ \\
Rhuthenium-106 & $6.3 \times 10^{2} \mathrm{Ci}$ \\
Cesium-137 & $1.6 \times 10^{4} \mathrm{Ci}$ \\
Other fission and activation & \\
$\quad$ radionuclides & $7.4 \times 10^{5} \mathrm{Ci}$ \\
General waste (sanitary landfi11) & $27,000 \mathrm{~m}^{3}$ \\
Hazardous chemicals & $750 \mathrm{~m}^{3}$ \\
Asbestos & $2,200 \mathrm{~m}^{3}$
\end{tabular}

\section{ACCIDENTAL RELEASES}

Several unplanned releases of contaminants occurred in 1978 as a result of accidents or other unusual occurrences (equipment or instrumentation malfunctions, operator errors, and design errors or inadequacies). The releases included discharges into several environmental media and two instances of wildlife contamination. The instances of wildlife contamination represent isolated cases associated with identifiable sources of radioactivity and do not reflect the general condition of the Hanford Site as shown in 
previous sections of this report. All of the releases had negligible impact on the environment and, for the most part, the impact was confined to the immediate vicinity of the release.

Further details and the corrective actions taken to prevent a recurrence of these releases are contained in the occurrence reports summarized below. These reports may be found in the public reading room of the Hanford Science Center in Richland, Washington.

Airborne Effluents

Three accidental releases of airborne contaminants to the atmosphere occurred during 1978. All of these releases involved radioactive material. A brief description of each release and its environmental impact is presented below.

\section{RHO Occurrence Report No. $78-20-2 / 14 / 78$}

A steam jet being used to transfer radioactive liquid waste between tanks in-the 200 East Area was left on after the feed tank had been emptied, causing some radioactive waste to be aspirated and discharged to the atmosphere. A small but undetermined quantity of radioactivity was released to the environment. The results of air samples taken in the vicinity showed that environmental air concentrations were well within applicable guidelines for uncontrolled areas.

\section{RHO Occurrence Report No. $78-130-12 / 2 / 78$}

Contaminated air in the void space of an underground storage tank for radioactive wastes in the 200 East Area was discharged to the atmosphere via an unfiltered air inlet vent while the tank was being filled. A small but undetermined quantity of radioactive material was released to the environment. Air samples taken in the vicinity showed no unusual airborne radionuclide concentration.

BNW Occurrence Report No. 78-9

Construction of a new stack-sampling system on the 231-Z facility in the 200 West Area resulted in the ability to take a more representative sample of the building's airborne effluents. With the new system, it was found that 
stack concentrations of plutonium exceeded the Concentration Guides of Manual Chapter 0524 Appendix and that this situation had existed for some time. The cause was determined to be contamination in the exhaust system downstream from the high-efficiency particulate air filters. The more contaminated portions of the exhaust system have been replaced and plutonium concentrations in the effluent are now within the Concentration Guides. None of the air samples taken at the four environmental air sampling stations in the vicinity of $231-Z$ have indicated that the release had any measurable impact on local air concentrations of plutonium.

\section{Liquid Effluents}

Three accidental releases of liquid to the Columbia River occurred in 1978, all involving violations of the temperature limit on the NPDES permit. In addition, there were four unplanned releases of liquid to the soil. These seven releases are described below.

UNI Occurrence Report No. 78-14 - 5/25/78

Heated demineralized water was released to the Columbia River at the 100- $\mathrm{N}$ Area at a temperature of $125^{\circ} \mathrm{F}, 25^{\circ} \mathrm{F}$ higher than the temperature limit for discharge point 005 on the NPDES permit. Noncompliance existed for 1 hour.

UNI Occurrence Report No. 78-23 - 8/15/78

An increase in the power level of $\mathrm{N}$ Reactor during startup procedures was not accompanied by an increase in the turbine generator load. The resulting excess heat was dissipated to the dump condensers. Temperatures in the condenser cooling water released to the Columbia River at the 100-N Area at discharge point 009 increased to a maximum of $93^{\circ} \mathrm{F}$, about $10^{\circ} \mathrm{F}$ higher than the maximum daily temperature limit on the NPDES permit. Temperatures were in violation for 75 minutes.

UNI Occurrence Report No. 78-27-8/31/78

Spillage of water from the After Heat Removal water storage tank at the 100-N Area resulted in releases to the Columbia River from discharge point 005 
exceeding the maximum daily temperature limit of $100^{\circ} \mathrm{F}$ by $5^{\circ} \mathrm{F}$. The duration of the violation was approximately 1.5 hours.

UNI Occurrence Report No. 78-7 - 3/8/78

A leak in the dummy fuel spacer transfer line extending from the $100-\mathrm{N}$ fuel storage basin to the dummy disposal pit resulted in the release to the soil of an estimated $0.5 \mathrm{Ci}$ of mixed fission and activation product radionuclides.

RHO Occurrence Report No. 78-38 - 4/12/78

Concentrations of alpha-emitting radionuclides in excess of operating limits were detected in liquid discharged to the Z-19 ditch in the 200 West Area. Concentrations during the violation period (less than 8 hours) were 8 times higher than the limit. The apparent cause of the release was a release of acid solution to the drain system, causing leaching of radioactivity on the drain pipe walls. None of the feeder stream samples showed unusual activity in the effluents.

RHO Occurrence Report No. 78-47 - 5/8/78

Condensate suspected to be from the Vent Header Extension Seal Loop of the underground storage tank was observed draining to the 216-A-8 crib in the 200 East Area. Analysis of samples of the liquid revealed radionuclide concentrations 10 times higher than operating limit specifications. The apparent cause of the release was a flaw in the original design that failed to provide a return flow path to the underground tank storage for the condensate.

RHO Occurrence Report No. $78-79-8 / 2 / 78$

Concentrations of alpha-emitting radionuclides in excess of action limits were detected in liquid discharged to the Z-19 ditch in the 200 West Area. The concentrations were about 2 times the action limit. The apparent cause of the release was the introduction of insufficiently diluted acid into the chemical drain system, resulting in the leaching of radioactivity from the drain system's pipe walls. 


\section{Solid Wastes}

Four unplanned releases of solid wastes, all involving radioactive material, occurred in 1978. Two involved wildlife contamination and the other two involved soil contamination. Brief descriptions of these releases are presented below.

RHO Occurrence Report No. $78-36-4 / 4 / 78$

Coyote feces contaminated with ${ }^{241} \mathrm{Am}$ and ${ }^{239} \mathrm{Pu}$ were discovered in the 200 West Area during a routine radiation survey. Followup surveys and the collection of small animals did not reveal the source of the contamination. A more extensive routine surveillance program has been initiated to trace sources of radioactive material accessible to small animals. The environmental impact of this release is minimal because of its isolated nature and its relative resistance to further dispersion in the environment.

RHO Occurrence Report No. 78-71-9/8/78

A swallow's nest in the rafter framework of the 202-S Building's dock was found to be contaminated with radioactive material. Contaminated mud in an open concrete catch basin in the 204-S tank area was the apparent source of the nest material. The catch basin receives contaminated liquids from condensate lines, tank overflows, and steam lines. Blowing dust mixed with the liquid to produce the contaminated mud. Procedures have since been changed to include periodic flushing of the basin to prevent the accumulation of mud. In addition, the 204-S facility is to be replaced. The environmental impact of this occurrence is minimal because of its isolated nature.

RHO Occurrence Report No. 78-97 - 9/8/78

A small amount of gravel was contaminated with plutonium during the transportation of a contaminated hood panel from the 234-5-Z Building to a burial area just south of the building in the 200 west Area. A tear in the plastic wrapping around the panel resulted in the release of a small amount of plutonium. The contaminated gravel was scooped up and disposed of in an approved manner. 


\section{RHO Occurrence Report No. $78-128-10 / 24 / 78$}

Radioactive contamination was discovered in an uncontrolled area near the 241-S and 241-SX underground waste storage tank farms in the 200 East Area. The contamination is suspected to have resulted from windborne contaminated soil and other removable surface contamination originating in the tank farms. Action has been taken to remove the source of the contamination and prevent a recurrence. Environmental air samples taken in the vicinity of the tank farms have from time to time shown radionuclide concentrations above those in more remote locations. These concentrations, however, have been well within applicable guidelines for uncontrolled areas. 


\section{REFERENCES}

Anderson, J. D., and B. E. Poremba. 1979a. Radioactive Liquid Wastes Discharged to Ground in the 200 Areas During 1978. RHO-LD-78-34 4Q, Rockwe 11 Hanford Operations, Richland, Washington.

Anderson, J. D., and B. E. Poremba. 1979b. Summary of Radioactive Solid Waste Burials in the 200 Areas During 1978. RHO-LD-78-24 4Q Rev. 1, Rockwel1 Hanford Operations, Richland, Washington.

Blumer, P. J., J. R. Houston and P. A. Eddy. 1977. Master Schedule for CY-1978 Hanford Environmental Surveillance Routine Program. PNL-2432, Pacific Northwest Laboratory, Richland, Washington.

Brauer, F. P., and J. H. Kaye. 1973. "Detection Systems for the Low Level Radiochemical Analys is of Iodine-131, Iodine-129 and Natural Iodine in Environmental Samples." BNWL-SA-4726, Pacific Northwest Laboratory, Richland, Washington.

Dorian, J. J., and V. R. Richards. 1978. Radiological Characterization of the Retired 100 Areas. UNI-946, United Nuclear Industries, Inc., RichTand, Washington.

Eddy, P. A. 1979. Radiological Status of the Ground Water Beneath the Hanford Project - January-December 1978. PNL-2899, Pacific Northwest Laboratory, Richland, Washington.

Fix, J. J. 1976. "Association of Long-Lived Radioactivity with Sediment Along the Columbia River Shoreline, Islands, Bottom and Slough Area." BNWL-SA-4584, Pac if ic Northwest Laboratory, Richland, Washington.

Fix, J. J., and M. L. Miller. 1978. The Hanford Environmental CaF2:Mn Thermoluminescent Dosimeter. PNL-24 $\overline{89}$, Pacific Northwest Laboratory, Richland, Washington.

Fix, J. J., and D. E. Robertson. 1976. "A 'Filter-Resin' Sampling Method for Measurement of Radioactivity in Columbia River Water." BNWL-SA-5630, Pacific Northwest Laboratory, Richland, Washington.

Greager, E. M. 1979. United Nuclear Industries, Inc. Reactor and Fuels Production Facilities 1978 Effluent Release Report. UNI-1261, United Nuclear Industries, Inc., Richland, Washington.

Houston, J. R., and P. J. Blumer. 1979. Environmental Surveillance at Hanford for CY-1978. PNL-2932, Pacific Northwest Laboratory, Richland, Washington.

Houston, J. R., and P. J. Blumer. 1978. Environmental Status of the Hanford Reservation for CY-1977. PNL-2677, Pacific Northwest Laboratory, Richland, Washington. 
Miller, M. L., J. J. Fix and P. E. Bramson. 1977. Radiochemical Analyses of Soil and Vegetation Samples Taken from the Hanford Environs, 1971-1976. BNWL-2249, Pacific Northwest Laboratory, Richiand, Washington.

Oakley, D. T. 1972. Natural Radiation Exposure in the United States. ORP/SID 72-1, U.S. Environmental Protection Agency, Washington, D.C.

Philipp, L. D., and E. M. Sheen. 1965. Aerial and Ground Gamma Survey Monitors. BNWL-62, Pacific Northwest Laboratory, Richland, Washington.

Speer, D. R., and D. A. Waite. 1975. "Statistical Distributions as Applied to Environmental Surveillance Data." BNWL-SA-5482, Pacific Northwest Laboratory, Richland, Washington.

U.S. Energy Research and Development Administration (ERDA). 1973. "Standards for Radiation Protection." In ERDA Manual, Chapter 0524 Appendix, Annex A. U.S. ERDA, Washington, D.C.

U.S. Environmental Protection Agency. 1972. Estimates of Ionizing Radiation Doses in the United States 1960-2000. ORP/CSD 72-1, Rockville, Maryland. 


\title{
APPENDIX
}

SPECIFIC SAMPLING LOCATIONS AROUND HANFORD FACILITIES

\author{
100-D Area \\ 100-K Area \\ 100-N Area \\ 200 East Area \\ 200 West Area \\ 300 Area
}



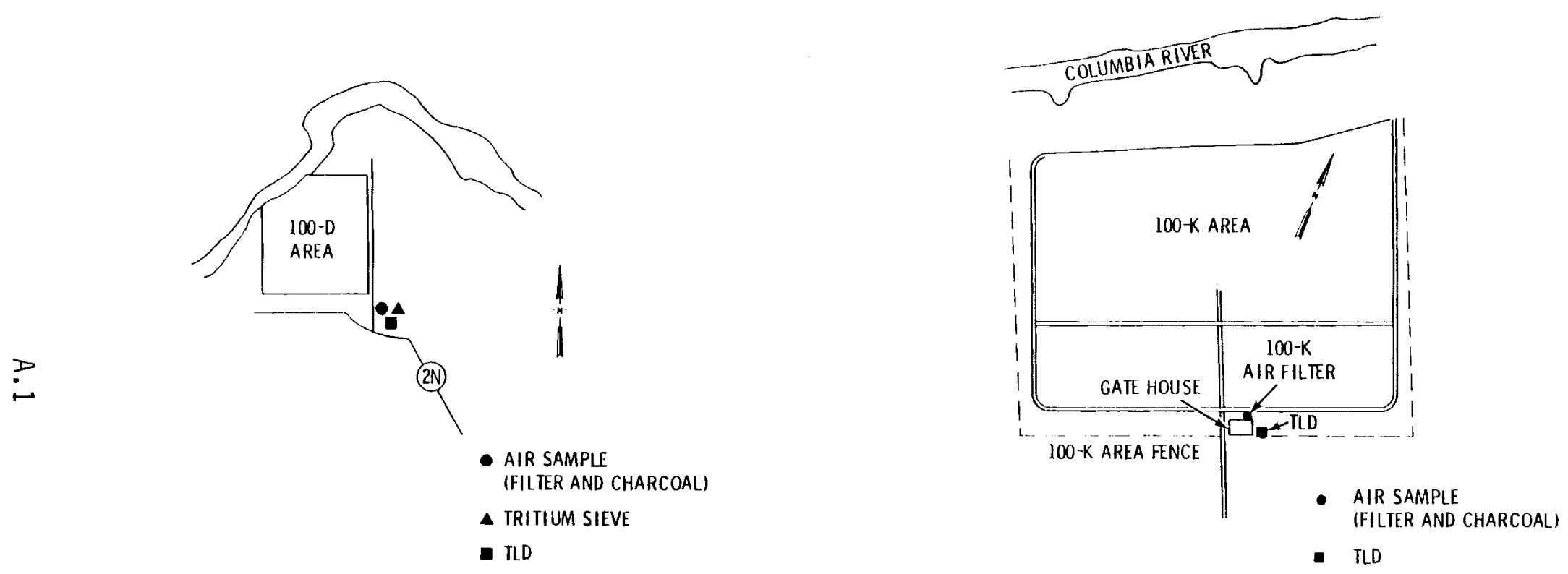

FIGURE A.1. Sampling Locations in the 100-D Area

FIGURE A.2. Sampling Locations in the 100-K Area 


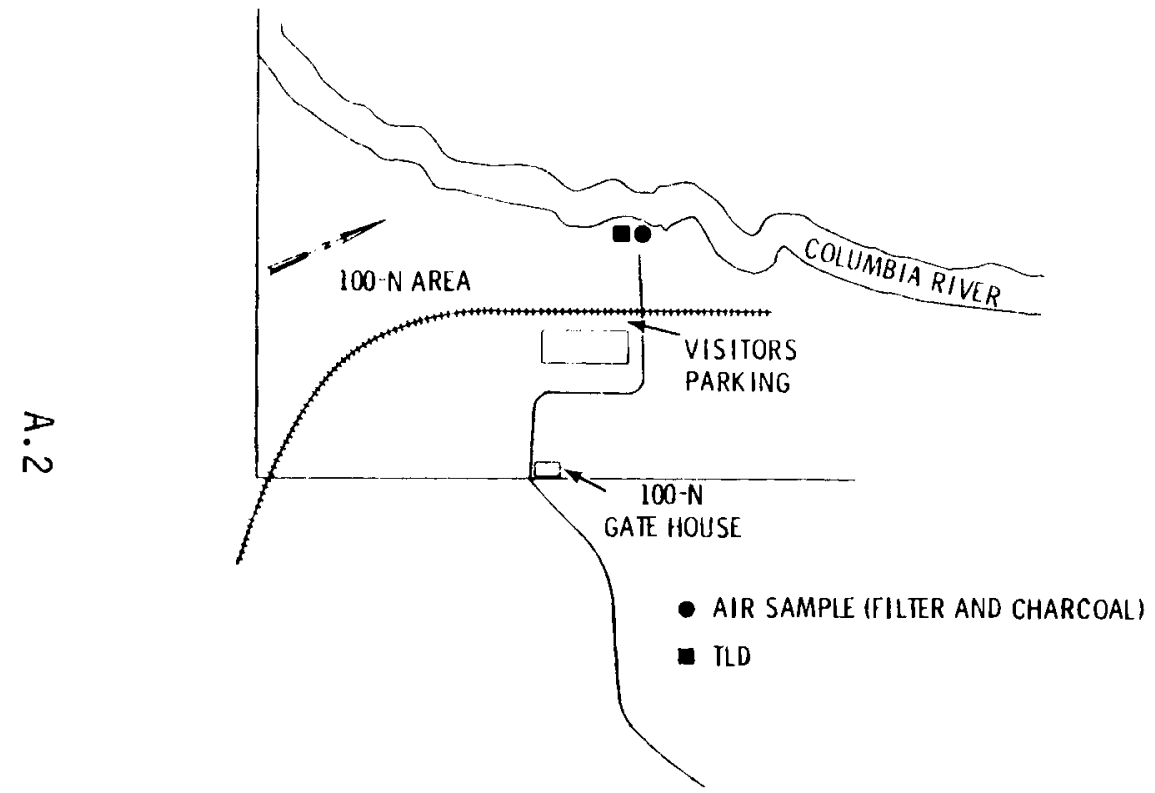

FIGURE A.3. Sampling Locations in the 100-N Area

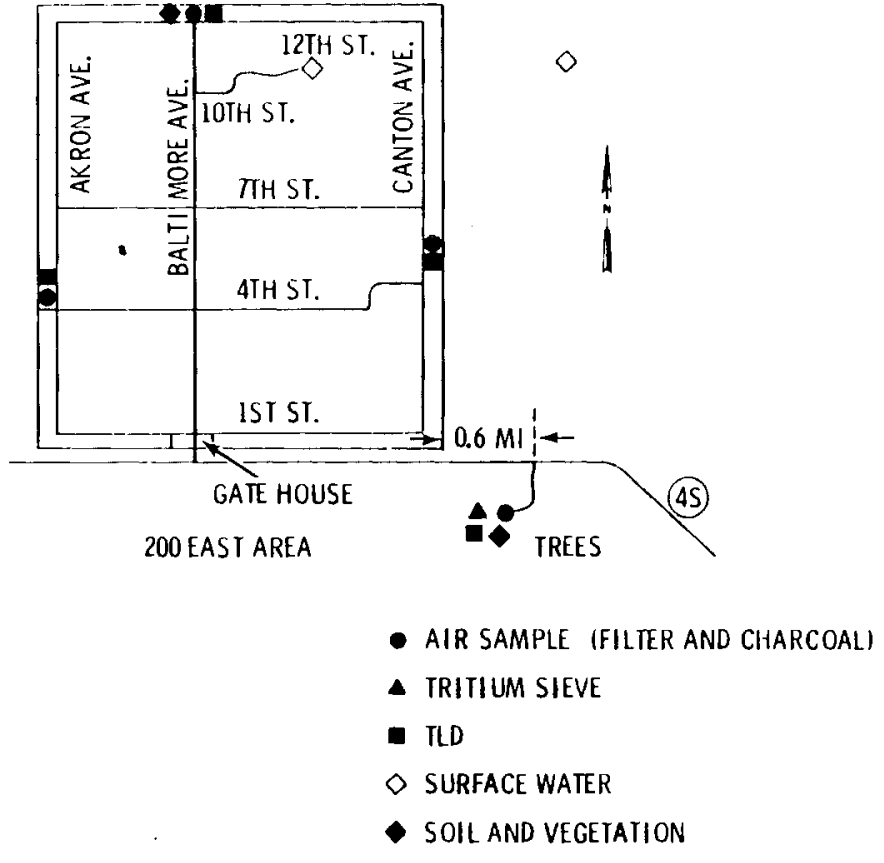

FIGURE A.4. Sampling Locations in the 200 East Area 


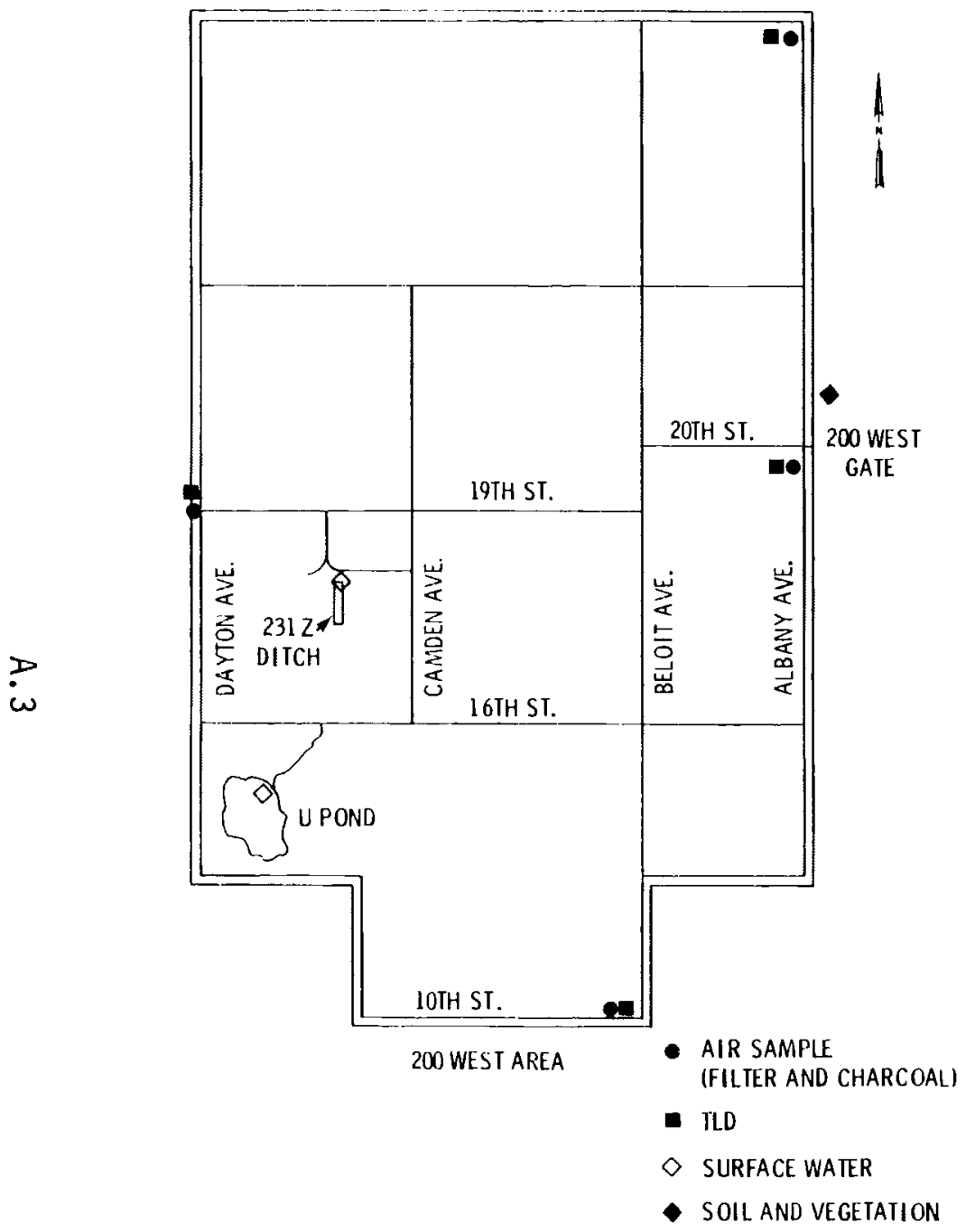

FIGURE A.5. Sampling Locations in the 200 West Area

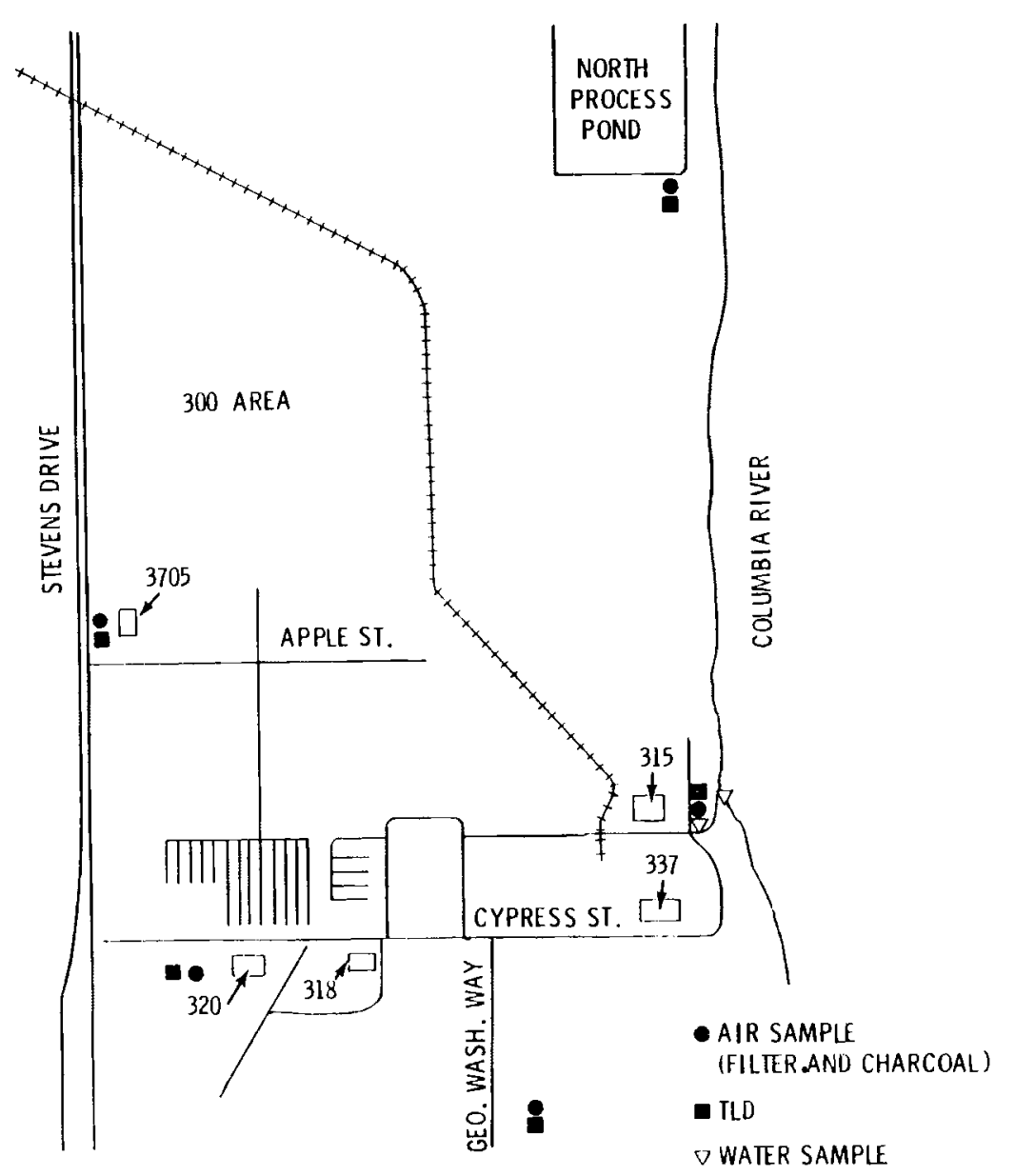

FIGURE A.6. Sampling Locations in the 300 Area 


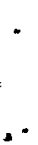

.

$-$ 
PNL-2933

UC -41

\section{DISTRIBUTION}

No. of

Copies

OFFSITE

A.A. Churm

DOE Patent Division

2900 South Cass Avenue

Argonne, IL 60439

27 DOE Technical Information

Center

ONSITE

11 DOE Richland Operations Office

D. R. Elle (6)

O. J. Elgert

H. E. Ransom

L. F. Perkins

M. W. Tiernan

M. G. White

6 Rockwel1 Hanford Operations

G. L. Hanson

W. F. Heine

J. V. Panesko

F. A. Spane

R. E. Wheeler

RHO Files

Hanford Environmental Health

Foundation

B. D. Reinert

5 UNC Nuclear Industries, Inc.

T. E. Dabrowski

L. P. Diediker

J. J. Dorian

L. Poppe

UNI Files
No. of

Copies

4 Westinghouse Hanford Co.

H. Bicehouse

G. D. Carpenter

R. B. Hall

J. M. McCarthy

70 Pacific Northwest Laboratory

G. E. Backman

J. L. Baer

P. J. Blumer

P. E. Bramson (2)

J. P. Cor ley

P. A. Eddy

J. R. Eliason

R. F. Foster

J. J. Fuquay

R. 0. Gilbert

W. M. Harty, Jr.

J. R. Houston (32)

J. J. Jech

H. V. Larson

S. J. Phillips

K. R. Price

M. R. Quarders (6)

L. L. Rader (2)

W. H. Rickard

G. R. Schreckhise

J. M. Selby

J. K. Soldat

M. J. Sula

C. M. Unruh

D. G. Watson

Technical Information (5)

Publishing Coordination Ei (2) 


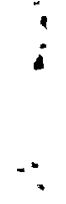

$\stackrel{\cdot}{\circ}$ 